\title{
Nitrido Technetium-99m Core in Radiopharmaceutical Applications: Four Decades of Research
}

\author{
Cristina Bolzati ${ }^{1, *}$ and Alessandro Dolmella ${ }^{2}$ \\ 1 Institute of Condensed Matter Chemistry and Technologies for Energy ICMATE-CNR, Corso Stati Uniti, 4, \\ I-35127 Padova, Italy \\ 2 Department of Pharmaceutical and Pharmacological Sciences, University of Padova, Via Marzolo, 5, \\ I-35131 Padova, Italy; alessandro.dolmella@unipd.it \\ * Correspondence: cristina.bolzati@cnr.it; Tel.: +39-049-827 5352; Fax: +39-049-827-5366
}

Received: 12 November 2019; Accepted: 23 December 2019; Published: 31 December 2019

check for updates

\begin{abstract}
The knowledge on element 43 (Tc) of the periodic table, built over the years through the contributions given by the close relationship between chemistry and nuclear medicine, allowed the development of new and increasingly effective radiopharmaceuticals useful both as perfusion and target specific imaging agents for SPECT (single photon emission tomography). Among the manifold Tc-compounds, $\operatorname{Tc}(V)$ nitrido complexes played a relevant role in the search for new technetium- $99 \mathrm{~m}$ radiopharmaceuticals, providing efficient labeling procedures that can be conveniently exploited for the design and synthesis of agents, also incorporating small organic molecules or peptides having defined structural features. With this work, we present an overview of four decades of research on the chemistry and on the nuclear medicine applications of $\mathrm{Tc}(\mathrm{V})$ nitrido complexes.
\end{abstract}

Keywords: nitrido complexes; technetium-99m; radiopharmaceuticals; imaging; target specific compounds

\section{General Properties of the $\mathrm{T} c \equiv N$ Group}

In 1972, Griffith [1] noted that, in view of the stability of rhenium nitrido complexes, it should also be possible to prepare $\mathrm{T} c \equiv \mathrm{N}$ analogues. Nevertheless, it was only in 1981 that the preparation of the first $\mathrm{T} \mathrm{C} \equiv \mathrm{N}$ compound was reported by Baldas and coworkers [2]. Since then, the chemistry of technetium nitrido complexes has been actively explored and a variety of $\left[{ }^{99 \mathrm{~m}} \mathrm{Tc}\right] \mathrm{Tc} \equiv \mathrm{N}$ species have been prepared at tracer level (Tc concentration $10^{-7}-10^{-9} \mathrm{M}$ ) and investigated as potential radiopharmaceuticals (RPs).

Technetium nitrido complexes are characterized by the $[\mathrm{T} \mathrm{c} \equiv \mathrm{N}]$ multiple-bond unit. The nitrido nitrogen atom $\left[\mathrm{N}^{3-}\right]$ is a very strong $\pi$-electron donor, and when it acts as a terminal ligand, the moiety $[\mathrm{M} \equiv \mathrm{N}](\mathrm{M}=\mathrm{Tc}, \mathrm{Re})$ has a formal bond order of three (triple bond, 1.585-1.650 $\mathrm{\AA}$ ) due to the formation of one $\sigma$ and two $\pi$ bonds. The latter results from the overlap of occupied $p$ orbitals $\left(p_{x}\right.$ and $\left.p_{y}\right)$ of the nitrogen with the unoccupied $4 d$ orbitals of the metal $\left(d_{x z}, d_{y z}\right)$ having the right symmetry. A nice description of the molecular orbital overlap between Tc and the nitrido nitrogen atom has been provided by Duatti [3].

At the macroscopic level (Tc concentration $10^{-3}-10^{-4} \mathrm{M}$ ), $\mathrm{Tc} \equiv \mathrm{N}$ complexes can be prepared by using pre-reduced $\left[\mathrm{Tc}^{\mathrm{V}} \mathrm{NCl}_{2}\left(\mathrm{PPh}_{3}\right)_{2}\right]$ or $\left[\mathrm{Tc}^{\mathrm{VI}} \mathrm{NX}_{4}\right]^{-}(\mathrm{X}=\mathrm{Cl}, \mathrm{Br})$ intermediate compounds as starting materials, either by ligand exchange or by reduction/exchange reactions, respectively. For these compounds, coordination numbers (C.N.) of 5, 6, and 7 and square pyramidal (sp), trigonal bipyramidal $(t b p)$, distorted octahedral $(o c)$, pentagonal pyramidal $(p p)$, and bipyramidal $(p b p)$ geometries have been established by X-ray crystallography [4]. 
Due to the high negative charge and strong $\pi$-donor ability, $\mathrm{N}^{3-}$ stabilizes the Tc atom in high oxidation states ranging from $\mathrm{Tc}^{\mathrm{V}}$ to $\mathrm{Tc}^{\mathrm{VII}}$. $\mathrm{Tc}^{\mathrm{VI}}$ nitrides are considerably less stable and have the tendency to undergo reduction at the corresponding $\mathrm{Tc}^{\mathrm{V}}$-nitride complexes. Therefore, +5 is the most common oxidation number for the Tc-nitrido compounds; this corresponds to a $d^{2}$ electronic configuration for the metal. When the metal is in this oxidation state, the $[\mathrm{Tc} \equiv \mathrm{N}]^{2+}$ core is isoelectronic with the well-known $[\mathrm{Tc}=\mathrm{O}]^{3+}$ one. Like the latter, the $[\mathrm{Tc} \equiv \mathrm{N}]^{2+}$ moiety can be viewed as a soft Lewis acid, exhibiting a marked electrophilic behavior; hence, its preferred interaction is with soft Lewis bases (vide infra).

Noteworthy, the $\mathrm{T} \mathrm{c} \equiv \mathrm{N}$ bond is remarkably stable to protonation and cleavage by strong aqueous acids, affording an extensive aqueous solution chemistry. The $\mathrm{Tc} \equiv \mathrm{N}$ compounds show no tendency to disproportionate in aqueous solution, displaying a high inertness toward redox reactions. In addition, whereas poly-oxo species are common, only mono-nitrido compounds have been characterized.

The strongest $\pi$-donor ability of the nitrido nitrogen atom compared to oxo oxygen atom is shown by the shorter $\mathrm{Tc} \equiv \mathrm{N}$ length and by the longer $\mathrm{Tc}_{\mathrm{c}}-\mathrm{L}_{\mathrm{eq}}$ bond distances in nitrido complexes when the Tc oxidation number and ligands are the same. Again, the terminal nitrido group exerts a smaller steric effect, producing $\mathrm{N} \equiv \mathrm{Tc}-\mathrm{L}$ angles narrower than $\mathrm{O}=\mathrm{Tc}-\mathrm{L}$ ones. The stronger trans-labilizing effect operated by the $[\mathrm{T} \mathrm{c} \equiv \mathrm{N}]^{2+}$ core originates five-coordinated species rather than six-coordinated ones as for the $[\mathrm{Tc}=\mathrm{O}]^{+3}$ core; likewise, in six-coordinated $\mathrm{Tc} \equiv \mathrm{N}$-compounds, the trans ligand is only weakly bound. Finally, coordination of a tetradentate ligand to a $[\mathrm{Tc} \equiv N]^{2+}$ group is less favored than that of two separate bidentate ligands, presumably as a result of electronic effects induced by the nitrido group [5-8].

\section{Structural Features of Reported Five- and Six-Coordinated Nitride-Tc Complexes}

In the following section, we underline the structural features of published Tc-nitride compounds as found through appropriate searches performed in the Cambridge Crystallographic Data Centre (CCDC) repository [9]. In these searches, we considered only mononuclear compounds, disregarding Tc polynuclear or hetero-nuclear compounds in which Tc is accompanied by other metals (see Tables 1-3). For the sake of completeness, however, few exceptions were made to this rule to include the penta-coordinated dianion $\left[\mathrm{TcN}\left(\mathrm{S}_{2} \mathrm{CO}\right)_{2}\right]^{2-}$ (Table 1), forming a $\mathrm{K}^{+}$salt, and the monocationic six-coordinated complexes $\left[\mathrm{TcNBr}(\text { bipy })_{2}\right]^{+},[\mathrm{TcNCl}(14 \mathrm{~S} 4)]^{+}$, and $[\mathrm{TcNCl}(18 \mathrm{~S} 6)]^{+}$(vide infra, Table 2), all showing $\left[\mathrm{TcNX}_{4}\right]^{-/ 2-}$ counter anions.

For the ease of comparison, we organized available data first by separating five- from six-coordinated compounds (Tables 1 and 2). In each group, we further separated molecules by gathering together complexes of lower symmetry (LS) and higher symmetry (HS). Table 3 collects few compounds with intermediate C.N. (see below) and the few $\mathrm{Tc}(\mathrm{VI})$ complexes. Higher symmetry complexes include: (i) homoleptic tetrakis-monodentate compounds, (ii) homoleptic bis-bidentate complexes, and (iii) molecules showing tetradentate ligands. Lower symmetry complexes gather all the remaining entities: (i) heteroleptic bis, bis-monodentate compounds, or (ii) heteroleptic complexes showing mixed-ligand assemblies (e.g., tridentate + bidentate (" $3+2$ "), tridentate + monodentate $($ " $3+1$ ") , bidentate + monodentate, mixed monodentate $($ " $2+1+1$ ")). Usually, anionic, neutral, and cationic compounds are listed in the tables in this order; also, when anionic ligands are present, compounds with dianionic ligands are listed first. In the tables, we compared existing structures by listing selected structural parameters (among which bond lengths, bond angles, dihedral angles), as they can be obtained (without e.s.d's) from the CCDC by means of the Mercury interface [10]. 
Table 1. Structural parameters of higher symmetry (HS) five-coordinated $\mathrm{Tc}(\mathrm{V})$ nitride complexes and of lower symmetry (LS) five-coordinated $\mathrm{Tc}(\mathrm{V})$ nitride complexes.

\begin{tabular}{|c|c|c|c|c|c|c|c|c|}
\hline HS Compounds & Charge & $\begin{array}{l}\text { Donor } \\
\text { Set }\end{array}$ & $\tau$ & $x$ & $\Delta \mathrm{Tc}(\AA ̊)$ & $\begin{array}{c}\mathrm{dTc} \equiv \mathbf{N} \\
(\AA)\end{array}$ & Config. & Ref. \\
\hline$\left[\mathrm{TcN}(\text { Smetetraz })_{4}\right]^{2-}$ & $2-$ & $\mathrm{NS}_{4}$ & 0.02 & 0.32 & 0.58 & 1.611 & & [11] \\
\hline$\left[\mathrm{TcN}(\text { dedmiy })_{4}\right]^{2+}$ & $2+$ & $\mathrm{C}_{4} \mathrm{~N}$ & 0.02 & 0.22 & 0.36 & 1.604 & & [12] \\
\hline$\left[\mathrm{TcN}\left(\mathrm{S}_{2} \mathrm{CO}\right)_{2}\right]^{2-}$ & $2-$ & $\mathrm{NS}_{4}$ & 0.00 & 0.39 & 0.71 & 1.621 & trans & [13] \\
\hline$\left[\mathrm{TcN}(\mathrm{SCOCOS})_{2}\right]^{2-, \text { a }}$ & $2-$ & $\mathrm{NS}_{4}$ & 0.00 & 0.35 & 0.65 & 1.613 & trans & [14] \\
\hline$\left[\mathrm{TcN}(\mathrm{SCOCOS})_{2}\right]^{2-,}$ a & $2-$ & $\mathrm{NS}_{4}$ & 0.01 & 0.34 & 0.61 & 1.606 & trans & [15] \\
\hline$\left[\mathrm{TcN}(\mathrm{mnt})_{2}\right]^{2-}$ & $2-$ & $\mathrm{NS}_{4}$ & 0.00 & 0.32 & 0.59 & 1.590 & trans & [16] \\
\hline$\left[\mathrm{TcN}(\mathrm{dmit})_{2}\right]^{2-}$ & $2-$ & $\mathrm{NS}_{4}$ & 0.08 & 0.39 & 0.62 & 1.615 & trans & [17] \\
\hline$\left[\mathrm{TcN}(\mathrm{i}-\mathrm{mns})_{2}\right]^{2-}$ & $2-$ & $\mathrm{NSe}_{4}$ & 0.09 & 0.45 & 0.77 & 1.613 & trans & [18] \\
\hline$\left[\mathrm{TcN}(\mathrm{SCOCOS})\left(\mathrm{Et}_{2} \mathrm{dtc}\right)\right]^{-}$ & $1-$ & $\mathrm{NS}_{4}$ & 0.08 & 0.38 & 0.66 & 1.542 & & [19] \\
\hline $\mathrm{TcN}\left(\mathrm{Et}_{2} \mathrm{dtc}\right)_{2}$ & 0 & $\mathrm{NS}_{4}$ & 0.02 & 0.42 & 0.74 & 1.604 & trans & [2] \\
\hline $\mathrm{TcN}\left\{\left(\mathrm{SPPh}_{2}\right)_{2} \mathrm{~N}\right\}_{2}$ & 0 & $\mathrm{NS}_{4}$ & 0.08 & 0.37 & 0.60 & 1.608 & trans & [20] \\
\hline $\mathrm{TcN}\left(\mathrm{SCH}_{2} \mathrm{CH}_{2} \mathrm{PCy}_{2}\right)_{2}$ & 0 & $\mathrm{NP}_{2} \mathrm{~S}_{2}$ & 0.49 & 0.73 & $0.73(0.00)$ & 1.645 & & [21] \\
\hline $\mathrm{TcN}\left(\mathrm{SCH}_{2} \mathrm{CH}_{2} \mathrm{PPh}_{2}\right)_{2}$ & 0 & $\mathrm{NP}_{2} \mathrm{~S}_{2}$ & 0.51 & 0.67 & $0.60(0.01)$ & 1.638 & & [22] \\
\hline $\mathrm{TcN}\left(\mathrm{SCH}_{2} \mathrm{CH}_{2} \mathrm{CH}_{2} \mathrm{PTol}_{2}\right)_{2}{ }^{\mathrm{b}}$ & 0 & $\mathrm{NP}_{2} \mathrm{~S}_{2}$ & 0.81 & 0.81 & $0.00(0.00)$ & 1.650 & & [22] \\
\hline $\mathrm{TcN}\left(\mathrm{C}_{9} \mathrm{H}_{6} \mathrm{NS}\right)_{2}$ & 0 & $\mathrm{~N}_{3} \mathrm{~S}_{2}$ & 0.44 & 0.64 & $0.61(0.00)$ & 1.623 & trans, trans & [23] \\
\hline $\mathrm{TcN}$ (isodtc) $)_{2}$ & 0 & $\mathrm{~N}_{3} \mathrm{~S}_{2}$ & 0.42 & 0.50 & 0.64 & 1.613 & trans, trans & [24] \\
\hline $\mathrm{TcN}\left(\mathrm{HEt}_{2} \mathrm{tcb}\right)_{2}$ & 0 & $\mathrm{~N}_{3} \mathrm{~S}_{2}$ & 0.07 & 0.38 & 0.61 & 1.610 & trans, cis & [25] \\
\hline $\mathrm{TcN}($ eacyd) & 0 & $\mathrm{~N}_{3} \mathrm{~S}_{2}$ & 0.02 & 0.36 & 0.59 & 1.630 & & [26] \\
\hline $\mathrm{TcN}$ (etaai) & 0 & $\mathrm{~N}_{3} \mathrm{~S}_{2}$ & 0.10 & 0.41 & 0.59 & 1.620 & & [27] \\
\hline $\mathrm{TcN}$ (tcbatsc) & 0 & $\mathrm{~N}_{3} \mathrm{~S}_{2}$ & 0.19 & 0.49 & 0.62 & 1.617 & & [28] \\
\hline \multicolumn{9}{|l|}{ LS Compounds } \\
\hline $\mathrm{TcNPh}_{2}(\text { tpty })_{2}$ & 0 & $\mathrm{C}_{4} \mathrm{~N}$ & 0.11 & 0.36 & 0.48 & 1.603 & trans, trans & [29] \\
\hline $\mathrm{TcNPh}_{2}\left(\mathrm{PPh}_{3}\right)_{2}$ & 0 & $\mathrm{C}_{2} \mathrm{NP}_{2}$ & 0.85 & 0.91 & $0.56(0.01)$ & 1.632 & trans, trans & [29] \\
\hline $\mathrm{TcN}(\mathrm{tmbt})_{2}(\mathrm{TMG})_{2}$ & 0 & $\mathrm{~N}_{3} \mathrm{~S}_{2}$ & 0.26 & 0.55 & 0.66 & 1.615 & trans, trans & [30] \\
\hline $\mathrm{TcNCl}_{2}\left(\mathrm{PPh}_{3}\right)_{2}{ }^{\mathrm{c}}$ & 0 & $\mathrm{NP}_{2} \mathrm{Cl}_{2}$ & 0.36 & 0.56 & 0.60 & 1.602 & trans, trans & [31] \\
\hline $\mathrm{TcNCl}_{2}\left(\mathrm{PPh}_{3}\right)_{2}$ & 0 & $\mathrm{NP}_{2} \mathrm{Cl}_{2}$ & 0.36 & 0.56 & 0.60 & 1.600 & trans, trans & [32] \\
\hline $\mathrm{TcNCl}_{2}\left(\mathrm{PPh}_{2}-\mathrm{py}-\mathrm{P}\right)_{2}$ & 0 & $\mathrm{NP}_{2} \mathrm{Cl}_{2}$ & 0.35 & 0.56 & 0.60 & 1.594 & trans, trans & [33] \\
\hline $\mathrm{TcNCl}_{2}\left(\mathrm{AsPh}_{3}\right)_{2}$ & 0 & $\mathrm{NAs}_{2} \mathrm{Cl}_{2}$ & 0.38 & 0.58 & 0.62 & 1.601 & trans, trans & [34] \\
\hline $\mathrm{TcNCl}_{2}\left(\mathrm{HNPPh}_{3}\right)_{2}$ & 0 & $\mathrm{~N}_{3} \mathrm{Cl}_{2}$ & 0.02 & 0.35 & 0.59 & 1.589 & trans, trans & [35] \\
\hline $\mathrm{TcN}(\mathrm{morpba})\left(\mathrm{PPh}_{3}\right)$ & 0 & $\mathrm{~N}_{2} \mathrm{OPS}$ & 0.25 & 0.49 & 0.54 & 1.620 & & [36] \\
\hline $\mathrm{TcN}$ (saldtcz)(PPh 3$)$ & 0 & $\mathrm{~N}_{2} \mathrm{OPS}$ & 0.28 & 0.52 & 0.57 & 1.611 & & [24] \\
\hline $\mathrm{TcN}(\mathrm{Z}-\mathrm{Val}-\mathrm{dtc})\left(\mathrm{PPh}_{3}\right)$ & 0 & $\mathrm{~N}_{3} \mathrm{PS}$ & 0.27 & 0.55 & 0.62 & 1.621 & & [37] \\
\hline $\mathrm{TcN}($ ecobap $)\left(\mathrm{PPh}_{3}\right)$ & 0 & $\mathrm{~N}_{2} \mathrm{O}_{2} \mathrm{P}$ & 0.18 & 0.49 & 0.60 & 1.608 & & [38] \\
\hline $\mathrm{TcN}\left(\mathrm{OSiMe}_{2} \mathrm{OSiMe}_{2} \mathrm{O}\right)(\text { dedmiy })_{2}$ & 0 & $\mathrm{C}_{2} \mathrm{NO}_{2}$ & 0.13 & 0.42 & 0.54 & 1.620 & cis & [12] \\
\hline $\mathrm{TcN}\left(\mathrm{OSiMe}_{2} \mathrm{OSiMe}_{2} \mathrm{O}\right)($ dedmiy $)\left(\mathrm{PMe}_{2} \mathrm{Ph}\right)$ & 1) 0 & $\mathrm{CNO}_{2} \mathrm{P}$ & 0.20 & 0.48 & 0.56 & 1.579 & & [12] \\
\hline $\mathrm{TcN}(\mathrm{mnt})\left(\mathrm{PMe} \mathrm{P}_{2} \mathrm{Ph}\right)_{2} \mathrm{~d}$ & 0 & $\mathrm{NP}_{2} \mathrm{~S}_{2}$ & $\begin{array}{l}0.02 ; \\
0.00\end{array}$ & $\begin{array}{l}0.33 ; \\
0.30\end{array}$ & $0.58 ; 0.56$ & $\begin{array}{l}1.612 ; \\
1.624\end{array}$ & cis & [39] \\
\hline $\mathrm{TcN}\left\{\mathrm{Et}_{2} \mathrm{NC}(\mathrm{S}) \mathrm{NH}\right\}$ (triqui) $\left(\mathrm{PPh}_{3}\right)$ & 0 & $\mathrm{~N}_{2} \mathrm{PS}_{2}$ & 0.33 & 0.59 & 0.65 & 1.609 & & [28] \\
\hline $\mathrm{TcNCl}\left(\mathrm{SCH}_{2} \mathrm{CH}_{2} \mathrm{PCy}_{2}\right)\left(\mathrm{PPh}_{3}\right)$ & 0 & $\mathrm{NP}_{2} \mathrm{SCl}$ & 0.28 & 0.54 & 0.65 & 1.589 & & [21] \\
\hline $\mathrm{TcNCl}($ EtOpitc $)\left(\mathrm{PPh}_{3}\right)$ & 0 & $\mathrm{~N}_{2} \mathrm{SPCl}$ & 0.40 & 0.65 & $0.67(0.12)$ & 1.615 & & [40] \\
\hline $\mathrm{TcNCl}(\mathrm{PStbu})\left(\mathrm{PPh}_{3}\right)^{\mathrm{d}}$ & 0 & $\mathrm{NP}_{2} \mathrm{SCl}$ & $\begin{array}{l}0.48 ; \\
0.33\end{array}$ & $\begin{array}{l}0.62 ; \\
0.55\end{array}$ & $\begin{array}{c}0.55(0.04) ; 0.61 \\
(0.02)\end{array}$ & $\begin{array}{l}1.615 ; \\
1.606\end{array}$ & & {$[41]$} \\
\hline $\mathrm{TcNCl}(\mathrm{CYS}-\mathrm{Oet})\left(\mathrm{PPh}_{3}\right)$ & 0 & $\mathrm{~N}_{2} \mathrm{PSCl}$ & 0.20 & 0.46 & 0.59 & 1.605 & & [42] \\
\hline $\mathrm{TcNCl}_{2}\left(\mathrm{Ph}_{2} \mathrm{PCH}_{2} \mathrm{PPh}_{2} \mathrm{NH}\right)^{\mathrm{d}}$ & 0 & $\mathrm{~N}_{2} \mathrm{PCl}_{2}$ & $\begin{array}{l}0.15 ; \\
0.08\end{array}$ & $\begin{array}{l}0.42 ; \\
0.38\end{array}$ & $0.56 ; 0.58$ & $\begin{array}{l}1.611 ; \\
1.621\end{array}$ & cis & [43] \\
\hline
\end{tabular}

$\tau, \chi=$ trigonality indexes. For an ideal sp geometry, $\tau=\chi=0.00$; likewise, for an ideal tbp arrangement, $\tau=\chi=1.00$. $\Delta \mathrm{Tc}(\AA)$ is the displacement (in angstroms) of the Tc atom from the basal plane encompassing the atoms defining the base of the square pyramid; values in brackets indicate the Tc displacement from the mean plane encompassing the atoms defining the base of the trigonal bipyramid. $d T c \equiv N(\AA)=$ the length (in angstroms) of the Tc-N (nitrido) bond. Configuration (Config.) = informs about: (i) the reciprocal arrangement assumed by identical ligands (where present), (ii) the reciprocal arrangement of identical ligands and of different donor atoms within these ligands (where present), or (iii) the reciprocal arrangement assumed by identical donor atoms in polydentate ligands (where present). ${ }^{a}$ Two distinct polymorphs of same compound. ${ }^{b}$ In italics because structure is disordered. ${ }^{c}$ Dichloromethane solvate of compound with different structural parameters. ${ }^{\mathrm{d}}$ Values for two independent molecules in unit cell. 
Table 2. Structural parameters of higher symmetry (HS) and lower symmetry (LS) six-coordinated $\mathrm{Tc}(\mathrm{V})$ nitride complexes.

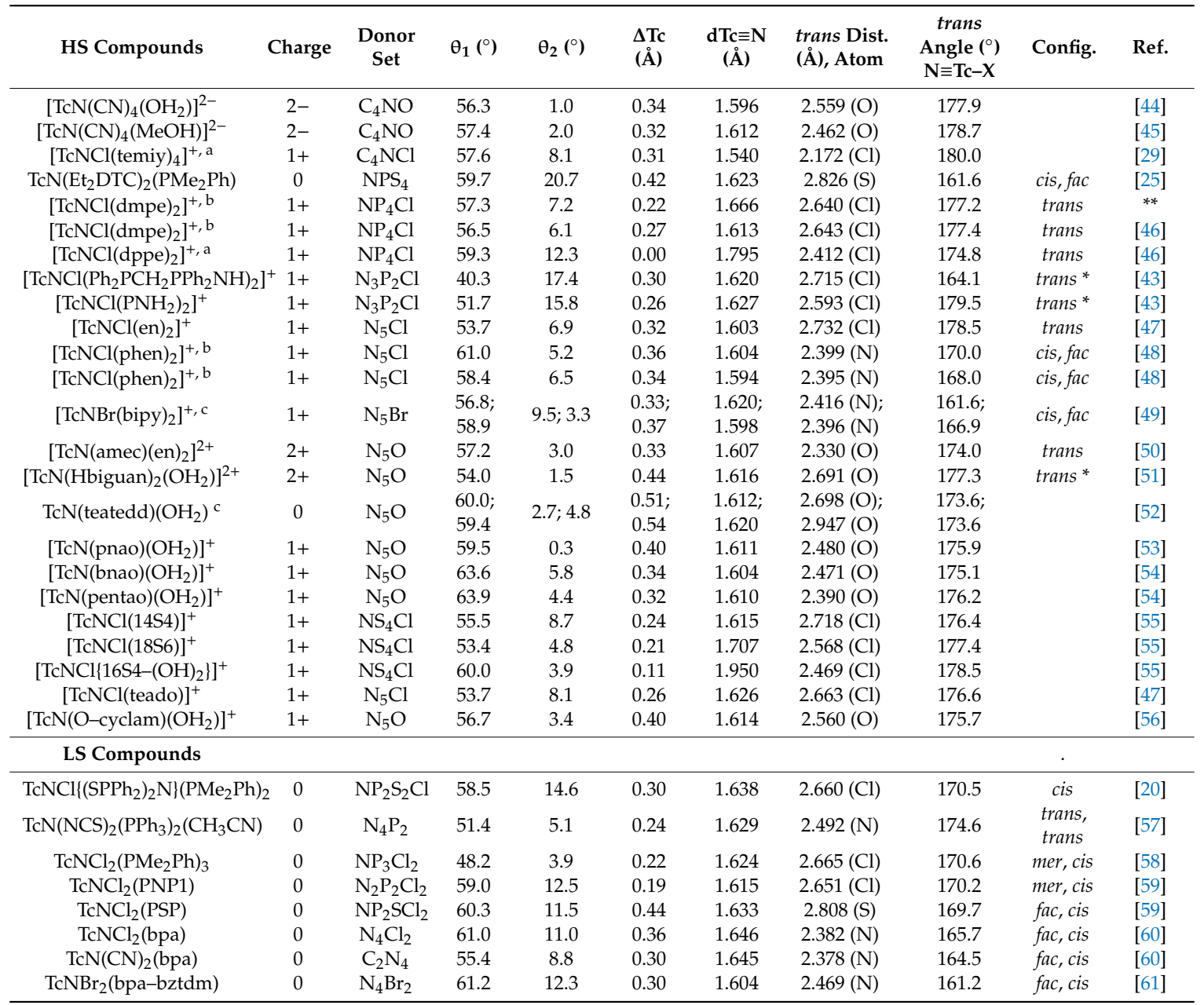

$\theta_{1}, \theta_{2}=$ angles (in degrees) used to evaluate the distortion from ideal octahedral arrangement, also in conjunction with the "trans angle $\mathrm{N} \equiv \mathrm{Tc}-\mathrm{X}$ " parameter. The $\theta_{1}$ or "twist" angle measures the shift among the vertexes of two opposing triangular faces of the octahedron. The value is taken by measuring the dihedral angle between the selected vertex of one triangular face, the geometric centroid of the same face, the geometric centroid of the opposing face, and the closest vertex of the opposing face. The $\theta_{2}$ or "tilt" parameter measures the dihedral angle existing among the mean planes encompassing the same two triangular faces considered to measure $\theta_{1}$. For an ideal octahedral environment, the values for $\theta_{1}$ and $\theta_{2}$ are 60.0 and $0.0^{\circ}$, respectively. trans dist. $(\AA)$, atom $=$ the distance (in angstroms) between Tc and the atom trans-positioned in respect of the nitrido ligand. trans angle $\left(^{\circ}\right) \mathrm{N} \equiv \mathrm{Tc}-\mathrm{X}=$ the $\mathrm{N} \equiv \mathrm{Tc}-\mathrm{X}$ bond angle (in degrees) formed by the nitrido ligand, the $\mathrm{Tc}$ atom, and the atom trans-positioned with respect to the nitrido ligand. Config. $=$ informs about the reciprocal arrangement assumed by identical ligands (where present); the additional fac indicator (where present) informs about the fact that a triangular face of the octahedron is taken by donor atoms of identical type; * compounds noted with an asterisk have identical ligands placed in reciprocal trans position but also have identical donor atoms (or substituent groups) of the ligand in reciprocal cis position ( $\mathrm{N}$ and $\mathrm{P}$ donors for the two compounds reported in [43], $\mathrm{Me}_{2} \mathrm{~N}$-residues in [51]). ${ }^{a}$ In italics because structure is disordered. ${ }^{\mathrm{b}}$ Complexes having the same cation but different counter anions and structural parameters. ${ }^{C}$ Values for two independent molecules in unit cell. ** Private communication (1996) to CCDC by U. Abram. 
Table 3. Structural parameters of Tc nitrido complexes with intermediate coordination number (top) and of Tc(VI) nitride compounds (bottom).

\begin{tabular}{|c|c|c|c|c|c|c|c|c|c|c|c|c|c|}
\hline $\mathrm{Tc}(\mathrm{V})$ Compounds & Charge & C.N. & $\begin{array}{c}\text { Donor } \\
\text { Set }\end{array}$ & $\bar{\tau}$ & $x$ & $\theta_{1}\left({ }^{\circ}\right)$ & $\theta_{2}\left({ }^{\circ}\right)$ & $\Delta \mathrm{Tc}(\AA ̊)$ & $\begin{array}{c}\mathrm{dTc} \equiv \mathbf{N} \\
(\AA))\end{array}$ & $\begin{array}{l}\text { trans Dist. } \\
(\AA) \text {, Atom }\end{array}$ & $\begin{array}{l}\text { trans Angle } \\
\left({ }^{\circ}\right) \mathrm{N} \equiv \mathrm{Tc}-\mathrm{X}\end{array}$ & Config. & Ref. \\
\hline$[\mathrm{TcN}(\mathrm{CN}) 4 \mathrm{py}]^{2-}$ & $2-$ & 5,6 & $\mathrm{C}_{4} \mathrm{~N}(\mathrm{~N})$ & 0.00 & 0.23 & 58.8 & 3.8 & 0.38 & 1.598 & $2.626(\mathrm{~N})$ & 179.0 & & {$[62]$} \\
\hline $\mathrm{TcNCl}_{2}(\mathrm{POOP})$ & 0 & 5,6 & $\mathrm{NP}_{2} \mathrm{Cl}_{2}(\mathrm{O})$ & 0.43 & 0.47 & 50.6 & 15.5 & 0.34 & 1.601 & $\begin{array}{c}2.885 * \\
(3.190)(\mathrm{O})\end{array}$ & $180 *(154.7)$ & $\begin{array}{c}\text { mer, trans } \\
\text { trans }\end{array}$ & [63] \\
\hline $\mathrm{TcNCl}_{2}(\mathrm{PN}(\mathrm{Pr}) \mathrm{P})$ & 0 & 5,6 & $\mathrm{NP}_{2} \mathrm{Cl}_{2}(\mathrm{~N})$ & 0.11 & 0.30 & 62.2 & 18.0 & 0.41 & 1.600 & $2.701(\mathrm{~N})$ & 161.9 & fac, cis & [63] \\
\hline $\mathrm{TcNCl}_{2}(\mathrm{POP})$ & 0 & 5,6 & $\mathrm{NP}_{2} \mathrm{Cl}_{2}(\mathrm{O})$ & 0.10 & 0.34 & 61.3 & 4.6 & 0.52 & 1.666 & $2.501(\mathrm{O})$ & 179.4 & mer, trans & [64] \\
\hline$[\mathrm{TcN}(\mathrm{Me}-\mathrm{dtcz})(\mathrm{POP})]^{+}$ & $1+$ & 5,6 & $\mathrm{~N}_{2} \mathrm{P}_{2} \mathrm{~S}(\mathrm{O})$ & 0.02 & 0.30 & 51.0 & 13.9 & 0.48 & 1.623 & $2.758(\mathrm{O})$ & 159.7 & $f a c$ & [65] \\
\hline$[\mathrm{TcN}(\mathrm{Medtcz})(\mathrm{PN}(\mathrm{etOMe}) \mathrm{P})]^{+}$ & $1+$ & 5,6 & $\mathrm{~N}_{2} \mathrm{P}_{2} \mathrm{~S}(\mathrm{~N})$ & 0.16 & 0.36 & 52.5 & 9.3 & 0.43 & 1.608 & $2.811(\mathrm{~N})$ & 161.8 & $f a c$ & [65] \\
\hline \multicolumn{14}{|l|}{$\mathrm{Tc}(\mathrm{VI})$ Compounds } \\
\hline$\left[\mathrm{TcNCl}_{4}\right]^{-}$ & $1-$ & 5 & $\mathrm{NCl}_{4}$ & 0.00 & 0.29 & & & 0.54 & 1.632 & & & & {$[66]$} \\
\hline$\left[\mathrm{TcNBr}_{4}\right]^{-}$ & $1-$ & 5 & $\mathrm{NBr}_{4}$ & 0.00 & 0.29 & & & 0.55 & 1.614 & & & & [67] \\
\hline$\left[\mathrm{TcNBr}_{4}\left(\mathrm{OH}_{2}\right)\right]^{-}$ & $1-$ & 6 & $\mathrm{NOBr}_{4}$ & & & 62.6 & 1.5 & 0.33 & 1.599 & $2.443(\mathrm{O})$ & 178.7 & & [68] \\
\hline $\mathrm{TcNCl}_{3}$ (bipy) & 0 & 6 & $\mathrm{~N}_{3} \mathrm{Cl}_{3}$ & & & 62.3 & 10.3 & 0.30 & 1.669 & $2.371(\mathrm{~N})$ & 165.5 & mer & [69] \\
\hline
\end{tabular}

Config. = (1) $\mathrm{Tc}(\mathrm{V})$ complexes: (a) in complexes having tridentate and bidentate ligands, it informs about whether or not the tridentate ligand attempts to take a triangular face of the monodentate ligands. (2) Complex $\mathrm{TcNCl}_{3}$ (bipy) [69]: it informs on the reciprocal orientation of the chloride ligands. ${ }^{*} \mathrm{Complex} \mathrm{TcNCl}_{2}\left(\mathrm{POOP}_{\text {) }} 63\right.$ ] is peculiar in having two, rather than one, donor atoms $(\mathrm{O})$ attempting to take the sixth coordination position of the octahedron. Starred figures refer to the geometric centroid of these oxygen donors; real values of trans distance and angles (identical by symmetry for the two oxygen atoms) in parentheses. 
These detailed structural parameters are meant to provide a support in design and development of new [ ${ }^{99} \mathrm{~m}$ Tc]TcN-RPs. The metrics might be helpful to evaluate the reactivity and the chemical stability of the complexes which, in turn, might affect their kinetic stabilities towards transchelation/transmetalation processes in vitro and in vivo.

To help readers, drawings of some ligands reported in Tables 1-3 are sketched in Figure 1 below.

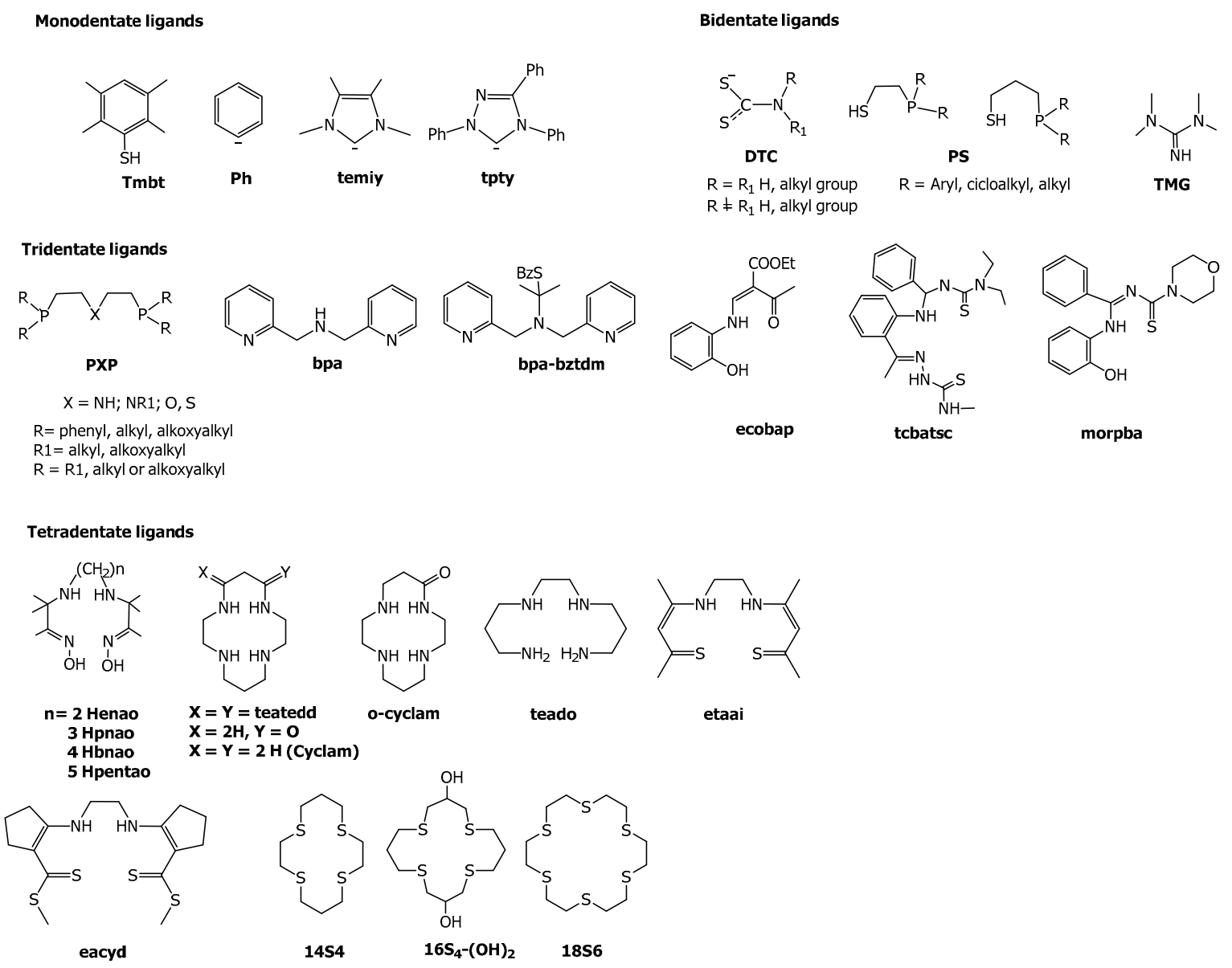

Figure 1. Schematic drawings of a selection of the ligands reported in Tables 1-3. For the complete chemical names see list of abbreviations.

The Tc-nitride complexes have been described in a rather large time window. The first data were published by Baldas et al. [2] in 1981 and, most recently, by Yoshimura et al. [60] in 2018. About two-thirds of these reports were published in the ten-year period $1990-2000$ with nearly only $25 \%$ of the total published in the past two decades. The search returned 83 structures (Tables 1-3); analysis of the data revealed that five- and six-coordinated species are almost equally represented and most of these are $\mathrm{Tc}(\mathrm{V})$ complexes, with the only exceptions of two five- and two six-coordinated $\mathrm{Tc}(\mathrm{VI})$ compounds (Table 3). Figure 2 displays a 3D-plot of contacting atoms versus oxidation number, coordination number, and complex symmetry. 


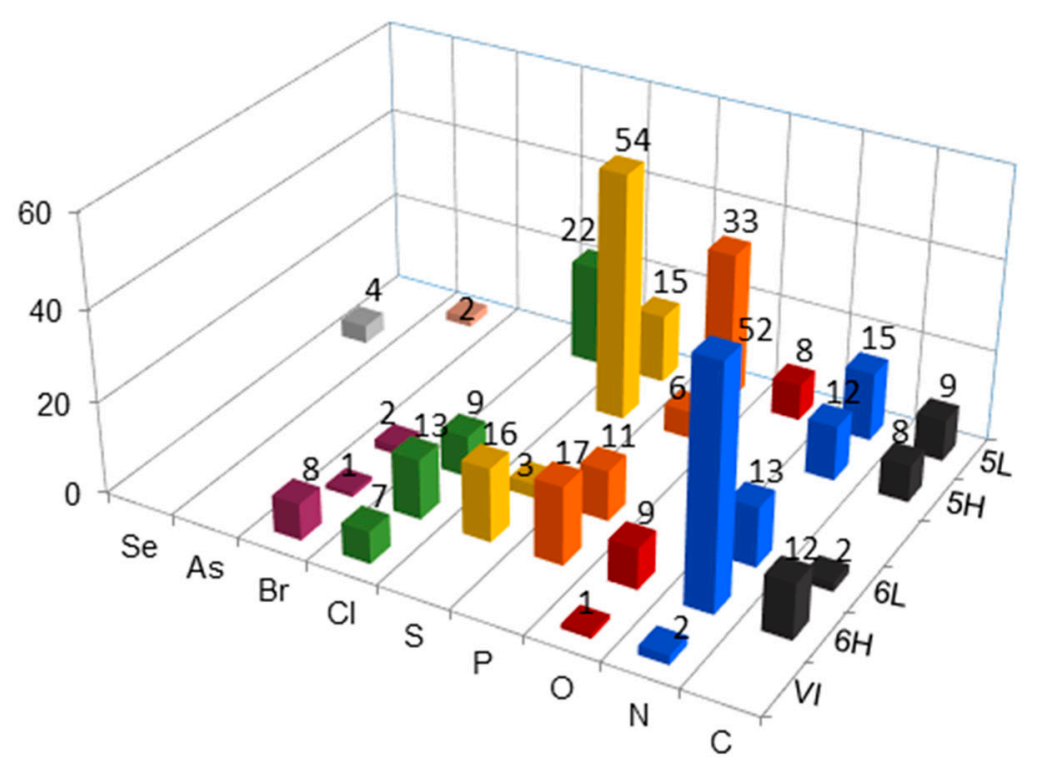

Figure 2. Contacting atoms versus oxidation number, coordination number, and complex symmetry. $5 \mathrm{~L}, 5 \mathrm{H}, 6 \mathrm{~L}, 6 \mathrm{H}=$ low and high five-coordinated and six-coordinated $\mathrm{Tc}^{\mathrm{V}}$-complexes, respectively; $\mathrm{VI}=$ five- and six-coordinated $\mathrm{Tc}^{\mathrm{VI}}$-complexes.

In these molecules, softer donors like phosphorous $(\mathrm{P})$, sulfur $(\mathrm{S})$, and halides are more represented $(61 \%)$ than harder ones like oxygen $(\mathrm{O})$, nitrogen $(\mathrm{N})$ or carbon $(\mathrm{C})(39 \%)$. In five-coordinated compounds, the $\mathrm{T} c \equiv \mathrm{N}$ group is mainly coordinated to softer donors, of which the most represented atom types are S, P, halides (almost always chloride) and N. In six-coordinated compounds, the balance between softer and harder donor is roughly in equilibrium. The most frequent donors in this group of compounds are $\mathrm{N}$ and halides (mostly chloride) followed by $\mathrm{P}$ and $\mathrm{S}$, that is, the same species as above, although in the reverse order.

\subsection{Five-Coordinated $\operatorname{Tc}(V)$ Complexes}

Five-coordinated compounds are summarized in Table 1. The LS complexes are more represented than HS ones. They are mostly neutral molecules, in which the charge of the $[\mathrm{Tc} \equiv \mathrm{N}]^{2+}$ core is counterbalanced frequently by sulfur-containing anionic ligands, (e.g., dithiocarbamates, dithiocarbazates, thiolates, thiurates, dithiocarbonate or dithiooxalate). There are only ten charged complexes, of which just one is cationic. Comparing HS and LS compounds (Figure 2, Table 1), it comes out that in both HS and LS complexes softer donors (like $S$ ) are more frequent than harder ones. Sulfur is the most frequent donor atom in HS compounds, and it is especially present in homoleptic bis-bidentate compounds. In LS compounds, the most common donors are P and chlorine, followed by equally represented $\mathrm{S}$ and $\mathrm{N}$.

Five-coordinated complexes may assume two ideal limiting geometries: square pyramidal ( $s p$ ) and trigonal bipyramidal $(t b p)$. To measure the deviation from the ideal $s p$ (or $t b p$ ) arrangement, the trigonality indexes proposed by Addison and coworkers $(\tau)$ [70] and Takumi and coworkers $(\chi)$ [71] were used. For an ideal $s p$ geometry, $\tau=\chi=0.00$; likewise, for an ideal tbp arrangement, $\tau=\chi=1.00$.

The data in Table 1 indicate that in HS compounds Tc has almost always a slightly distorted $s p$ environment. In LS compounds, the departures from an ideal $s p$ environment become larger; meanwhile, when noticeable deviations arise from the strain imposed by the chelating ligands also distorted tbp arrangements become accessible in a minority of the molecules. The choice between these limiting geometries is imposed by the nature of the four coordinating atoms around the $\mathrm{Tc} \equiv \mathrm{N}$ group. In general, a set of four $\pi$-donor atoms lead to the formation of $s p$ complexes; the tbp arrangement is instead preferred when the metal environment includes a combination of two $\pi$-donor and two 
$\pi$-acceptor atoms. As for the molecular orbitals, as well as for symmetry in these entities, we redirect interested readers to the work by Duatti [3].

In HS compounds, Tc assumes mostly a sp coordination geometry (Table 1). Deviations of the $\tau$ and $\chi$ values from ideal values are limited, especially in homoleptic tetrakis-monodentate and homoleptic bis-bidentate compounds, where all the atoms belonging to the basal plane of the pyramid are identical (Figure 3A). When donor atoms are different and the coordination sites are equally shared by a mix of $\pi$-donors as in the quinolinethiolate derivative $\mathrm{TcN}\left(\mathrm{C}_{9} \mathrm{H}_{6} \mathrm{NS}\right)_{2}(\tau=0.44 ; \chi=0.64)$ a considerable distortion from the $s p$ towards tbp arrangement is observed [23] (Figure 3B,C). As for isomerism, in these homoleptic bis-bidentate complexes the reciprocal position of identical ligands is always the expected trans one. The unique exception to this general behavior is given by the bis-benzamidinate $\mathrm{TcN}\left(\mathrm{HEt}_{2} \mathrm{tcb}\right)_{2}$, in which the $\mathrm{S}$ and $\mathrm{N}$ donors of the two ligands are instead in a cis disposition (trans, cis in Table 1; Figure 4) [25].

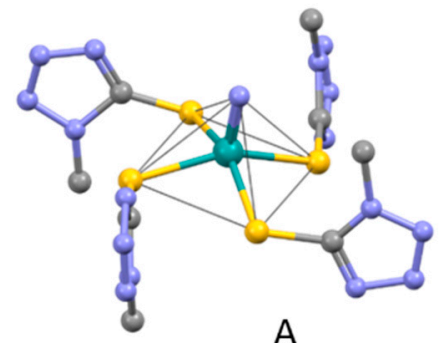

A

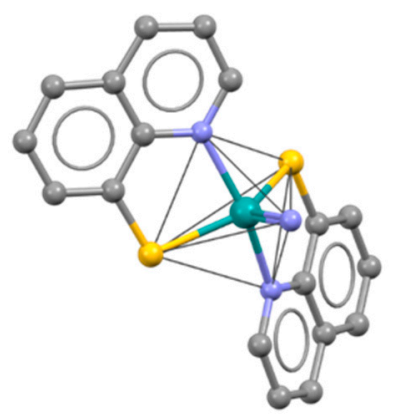

C

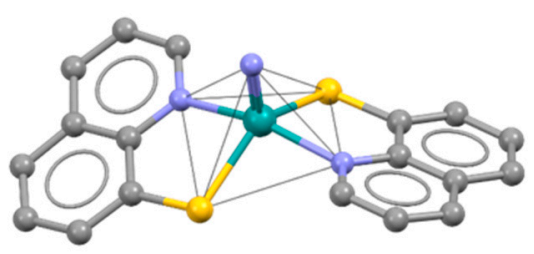

B

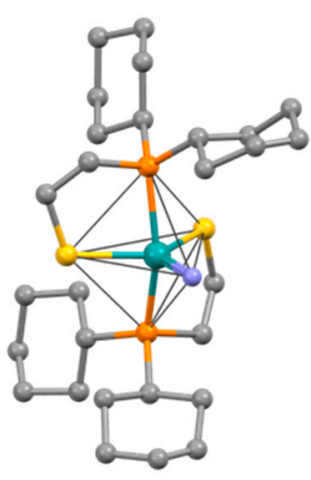

D

Figure 3. Square pyramidal versus trigonal bipyramidal geometries. Structures of $(\mathbf{A})\left[\mathrm{TcN}(\mathrm{Smetetraz})_{4}\right]^{2-}$, $(\mathbf{B}, \mathbf{C}) \mathrm{TcN}\left(\mathrm{C}_{9} \mathrm{H}_{6} \mathrm{NS}\right)_{2}$ in $s p$ and tbp arrangements, respectively; (D) $\mathrm{TcN}\left(\mathrm{SCH}_{2} \mathrm{CH}_{2} \mathrm{PCy}_{2}\right)_{2}$.

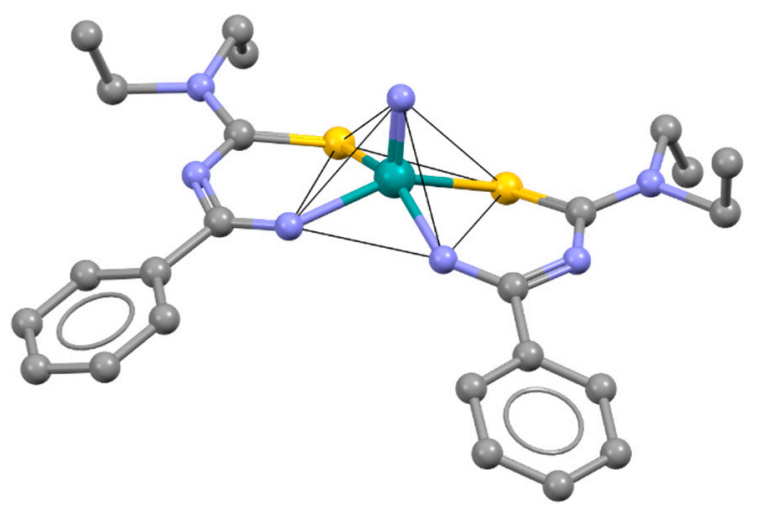

Figure 4. Structure of $\mathrm{TcN}\left(\mathrm{HEt}_{2} \mathrm{tcb}\right)_{2}$.

Noteworthy, when the set of coordinating atoms around the $\mathrm{T} c \equiv \mathrm{N}$ is formed by two $\pi$-donor and two $\pi$-acceptor atoms, as in the bis-phosphinothiolate complexes $\mathrm{TcN}\left(\mathrm{SCH}_{2} \mathrm{CH}_{2} \mathrm{PCy}_{2}\right)_{2}$, $\mathrm{TcN}\left(\mathrm{SCH}_{2} \mathrm{CH}_{2} \mathrm{PPh}_{2}\right)_{2}, \mathrm{TcN}\left(\mathrm{SCH}_{2} \mathrm{CH}_{2} \mathrm{CH}_{2} \mathrm{PTol}_{2}\right)_{2}$ [21,22], a distorted tbp arrangement becomes 
preferred. In this configuration, the two phosphorus atoms fill the two apical sites of the tbp and the two sulfur atoms and the nitrido nitrogen atom are located on the trigonal plane (Figure 3D). These structural features reveal the strong preference of $\pi$-acceptor phosphorus atoms to achieve a reciprocal trans-position, as opposed to the tendency of $\pi$-donor atoms to assume a mutual cis-configuration. The trans-P fashion, indeed, is retained also in some nitrido complexes of intermediate coordination number incorporating hetero bis-phosphines with a long bridge chain (eight- or seven-membered chain including the two $\mathrm{P}$ atoms) such as $\mathrm{TcNCl}_{2}$ (POOP) [63] or $\mathrm{TcNCl}_{2}$ (PNP7), again showing that the trans-P arrangement is preferred (vide infra).

As for molecules containing tetradentate ligands, such as TcN(eacyd), TcN(etaai), and TcN(tcbatsc), they usually exhibit $s p$ geometry with an apical nitrido nitrogen atom and the basal site filled by the dianionic tetradentate ligand, in which the two identical donor $\mathrm{S}$ and $\mathrm{N}$ atoms are facing each other as imposed by the steric constrain due to the denticity of the ligand (Figure 5) [26-28].

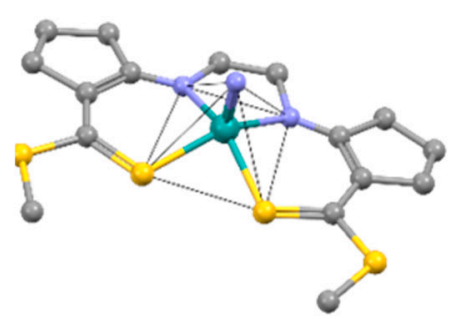

A

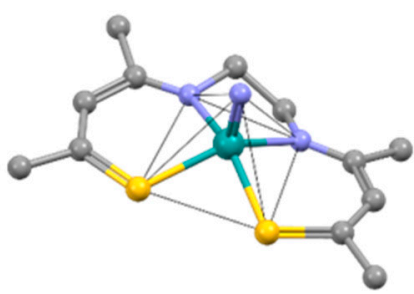

B

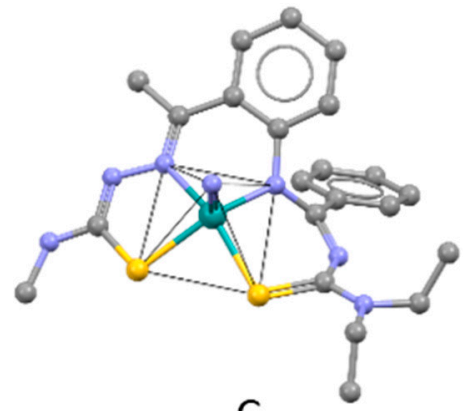

C

Figure 5. Structure of $\mathrm{TcN}($ eacyd) (A), TcN(etaai) (B), and $\mathrm{TcN}($ tcbatsc) (C).

The LS complexes (Table 1) are in general heteroleptic compounds with ligands of different kinds bound to the $\mathrm{Tc} \equiv \mathrm{N}$ group. All are neutral molecules because of the presence in the Tc coordination sphere of two mononegative donor atoms. In LS compounds, the inhomogeneity of the ligand assembly leads more frequently to deformed $s p$ geometries as witnessed by the values of the $\tau$ and $\chi$ indexes.

Distorted tbp geometries are infrequent and their formation is again correlated to the presence of mixed donor atoms in the coordination sphere, like in HS molecules, although in this group the drift towards the $t b p$ arrangement seems due to the fact of steric rather than electronic reasons, such as the need of accommodating an otherwise encumbered set of bulky residues, like in the case of $\mathrm{TcNPh}_{2}\left(\mathrm{PPh}_{3}\right)_{2}$ [29]. With respect to isomerism, complexes featuring two couples of identical monodentate ligands show them invariably in the reciprocal trans, trans disposition. Likewise, all complexes having a tridentate ligand show Tc and the donor atoms in the same plane, like in the complex TcN(morpba) $\left(\mathrm{PPh}_{3}\right)$ [36].

Other parameters used for comparison in five-coordinated compounds are the displacement in $\AA$ of the Tc atom from the basal plane of the square pyramid $\left(\Delta \mathrm{Tc}_{\mathrm{c}}\right)$ and the length in $\AA$ of the $\mathrm{T}_{\mathrm{c}} \equiv \mathrm{N}$ bond $(\mathrm{dTc} \equiv \mathrm{N})$. Evaluation of the data pertaining to HS and LS molecules indicates that in LS both structural parameters are shorter, on the average, than those found in HS complexes. By looking at Table 1, we can see that in HS compounds, the basal positions of the pyramid are taken mainly by sulfur atoms. From a merely geometric point of view, Tc-S distances are usually longer than Tc-C, Tc-N, Tc-O or Tc-P bonds, [9] so that the basal plane is brought farther away from Tc and the displacement of the metal grows higher. Besides, dianionic ligands are more frequent in HS compounds than in the LS group. Conceivably, these donors convey a greater charge contribution on $\mathrm{Tc}$, thus loosening somehow the $\mathrm{Tc} \equiv \mathrm{N}$ bond.

Thus, if at one hand these occurrences suggest that the Tc charge demand has been somehow satisfied, on the other one the rather long Tc-S distances hint to a possible pathway towards at least a partial substitution/replacement by more efficient chelating agents might be afforded in these complexes. 


\subsection{Six-Coordinated $T c(V)$ Complexes}

Six-coordinated compounds are summarized in Table 2; HS complexes are more represented than LS ones. Almost all HS complexes are charged species, especially cationic; on the contrary, LS ones are neutral. The group of HS compounds is the only one in which harder donors are more frequent than softer ones. The leading donor is $\mathrm{N}$, that is especially present in complexes showing homoleptic bis-bidentate as well as tetradentate ligands. The second and third most represented donors are $\mathrm{P}$ and S. In LS entities, softer donors dominate over harder ones, with $\mathrm{N}, \mathrm{P}$, and $\mathrm{Cl}$ donors almost equally represented (Figure 2).

Six-coordinated compounds all have a distorted octahedral (oc) geometry, which appear to be more regular in HS rather than in LS complexes. A common feature is that chelating ligands are frequently neutral molecules such as non-ionizable amines, amides or phosphines, hence promoting a shift towards hexa-coordination through the addition of a further monodentate ligand trans to the $\mathrm{T} c \equiv \mathrm{N}$ group. The largest deviation from the ideal $o c$ is the trans-axial lengthening of the Tc- $X$ distance $(X=$ monodentate ligand) induced by the nitrido group (trans-distance, Table 2). In these compounds bond lengths are all beyond $2.5 \AA$, more than $1.0 \AA$ longer than the $\mathrm{Tc} \equiv \mathrm{N}$ bond (approximately $1.6 \AA$ ). This lengthening becomes clearer in complexes containing dianionic and monoanionic tetradentate ligands, such as tetra-azacyclotetradecane derivatives, yielding compounds like TcN(teatedd) $\left(\mathrm{OH}_{2}\right)$ [52] and [TcN $(\mathrm{O}-$ cyclam $\left.)\left(\mathrm{OH}_{2}\right)\right]^{+}$[56], respectively, as well as with closely similar monoanionic tetradentate aza-alkane dioximate ligands, generating $\left[\mathrm{TcN}(\mathrm{pnao})\left(\mathrm{OH}_{2}\right)\right]^{+}[53]$, $\left[\mathrm{TcN}(\text { bnao })\left(\mathrm{OH}_{2}\right)\right]^{+}$, and $\left[\mathrm{TcN}(\text { pentao })\left(\mathrm{OH}_{2}\right)\right]^{+}$(Figure 6) [54].

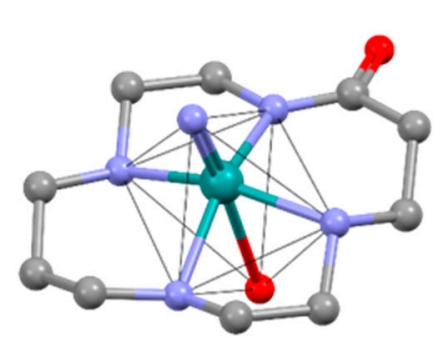

A

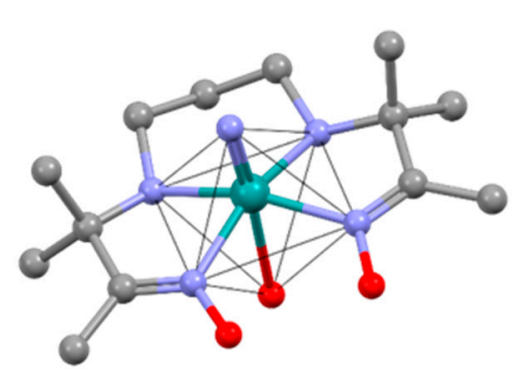

B

Figure 6. Structures of six-coordinated $\left[\mathrm{TcN}(\mathrm{O}-\mathrm{cyclam})\left(\mathrm{OH}_{2}\right)\right]^{+}(\mathbf{A})$ and $\left[\mathrm{TcN}(\mathrm{pnao})\left(\mathrm{OH}_{2}\right)\right]^{+}$(B).

The deviation from an ideal $o c$ arrangement was estimated by means of few structural parameters, such as the length of $\mathrm{T}_{\mathrm{c}} \equiv \mathrm{N}$ and $\mathrm{T}_{\mathrm{c}}-\mathrm{X}$ bonds, the $\Delta \mathrm{T}_{\mathrm{c}}$ from the $o c$ equatorial plane (in $\AA$ ) and the $\mathrm{N} \equiv \mathrm{Tc}-\mathrm{X}$ bond angle (or trans-angle, in degrees) made by the nitride ligand, the Tc atom and the atom trans to the nitride ion. Two additional angular parameters, $\theta_{1}$ and $\theta_{2}$ (Table 2), were also introduced; for an ideal $o c$ environment, the values for $\theta_{1}$ and $\theta_{2}$ are 60.0 and $0.0^{\circ}$, respectively.

There is an appreciable deviation from co-linearity only in those cases where the trans atom belongs to a bidentate ligand with a narrow "bite" angle, like $\mathrm{TcN}\left(\mathrm{Et}_{2} \mathrm{dtc}\right)_{2}\left(\mathrm{PMe}_{2} \mathrm{Ph}\right)$ [25], or when the bidentate ligands taking the four positions of the $o c$ equatorial plane have mixed donor atoms $(\mathrm{P}, \mathrm{N})$, like $\left[\mathrm{TcNCl}\left(\mathrm{Ph}_{2} \mathrm{PCH}_{2} \mathrm{PPh}_{2} \mathrm{NH}\right)_{2}\right]^{+}$or $\left[\mathrm{TcNCl}\left(\mathrm{PNH}_{2}\right)_{2}\right]^{+}[43]$.

The deviation from ideality is further indicated by the significant shift of the $\theta_{1}$ and $\theta_{2}$ angles from ideal values. As for isomerism, in homoleptic bis-bidentate complexes the two identical ligands usually assume the reciprocal trans position. The cis, bis-complexes form instead with bidentate ligands having narrower "bite" angles, like diethyldithiocarbamate, phenanthroline, and bipyridine. In these complexes, an entire face of the octahedron is taken by identical donor atoms, so that fac-isomers are also generated.

In HS compounds, the atom trans to the nitride is either a chloride ion or a water molecule. Exceptions are given by the phenanthroline $\left[\mathrm{TcNCl}(\text { phen })_{2}\right]^{+}[48]$ and bipyridine $\left.\left[\mathrm{TcNBr}(\text { bipy })_{2}\right)\right]^{+}[49]$ complexes as well as by the neutral $\mathrm{TcN}\left(\mathrm{Et}_{2} \mathrm{dtc}\right)_{2}\left(\mathrm{PMe}_{2} \mathrm{Ph}\right)$ complex [25] (Table 2). In LS molecules, this position is taken either by an amine nitrogen or a chloride, except for TcN(NCS $)_{2}\left(\mathrm{PPh}_{3}\right)_{2}\left(\mathrm{CH}_{3} \mathrm{CN}\right)$ [57], 
where the trans atom is the nitrogen atom of the acetonitrile moiety, and $\mathrm{TcNCl}_{2}$ (PSP) [59], where the position is occupied by a sulfur atom. Notably, the only two six-coordinated complexes where the trans position is taken by a sulfur atom share the very uncommon $[\mathrm{N} \equiv \mathrm{Tc}-\mathrm{S}]^{2+}$ core. The longest $\mathrm{T} \equiv \mathrm{N}$ distance ever recorded so far has been found instead in the macrocyclic thioether complex $\left[\mathrm{TcNCl}\left\{16 \mathrm{~S} 4-(\mathrm{OH})_{2}\right\}\right]^{+}$(Figure 7) [55]. All Tc-X trans-distances are markedly longer than those usually reported for singly bonded atoms, pointing to the strong trans-influence of the nitride ligand. Eventually, the trans $\mathrm{Tc}-\mathrm{S}$ distance in $\mathrm{TcN}\left(\mathrm{Et}_{2} \mathrm{dtc}\right)_{2}\left(\mathrm{PMe}_{2} \mathrm{Ph}\right)(2.826 \AA)$ is the longest Tc-S distance recorded so far [25]. On the opposite, the $\Delta \mathrm{Tc}$ from the basal plane of the octahedron is less pronounced than that observed in five-coordinated compounds, varying between 0.00 and $0.54 \AA$.

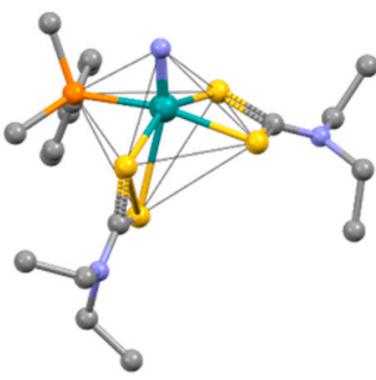

A

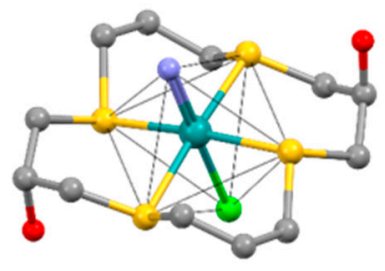

C

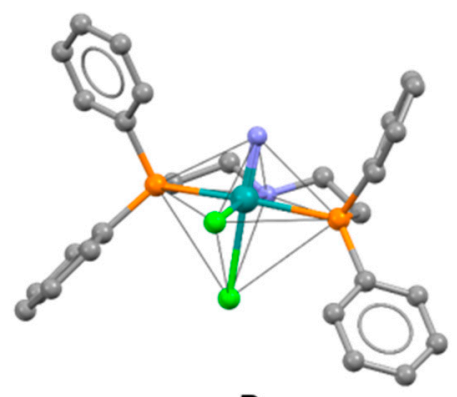

B

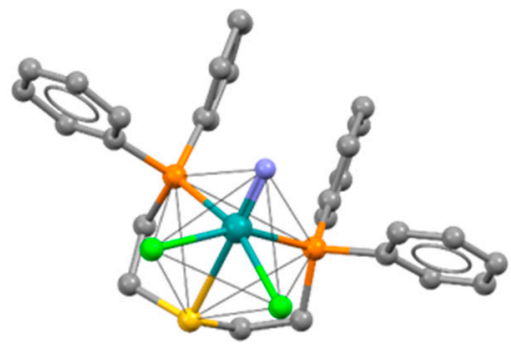

D

Figure 7. (A,B) HS: six-coordinated $\mathrm{TcN}\left(\mathrm{Et}_{2} \mathrm{dtc}\right)_{2}\left(\mathrm{PMe}_{2} \mathrm{Ph}\right)$ and $\left[\mathrm{TcNCl}\left\{16 \mathrm{SS} 4-(\mathrm{OH})_{2}\right\}\right]^{+} ;(\mathbf{C}, \mathbf{D}) \mathrm{LS}$ : six-coordinated $\mathrm{TcNCl}_{2}(\mathrm{PNP} 1)$ and $\mathrm{TcNCl}_{2}(\mathrm{PSP})$.

The LS complexes show a more appreciable deviation from an ideal oc geometry compared with HS compounds, as indicated by the $\mathrm{N} \equiv \mathrm{Tc}-\mathrm{X}$ trans angle and by the $\theta_{1}$ and $\theta_{2}$ angles. The LS molecules have in common the presence of two monoanionic monodentate ligands, usually chloride ions and a polydentate ligand, mainly neutral and tridentate (a diphosphinoamine or dipyridylamine derivative), whose presence might also impose some strain over the $o c$ arrangement. The sole exception to this kind of ligand assembly is provided by the previously described trans, trans-TcN(NCS $)_{2}\left(\mathrm{PPh}_{3}\right)_{2}\left(\mathrm{CH}_{3} \mathrm{CN}\right)$ [57], in which the two couples of identical ligands are in the reciprocal trans position. Where tridentate diphosphinoamine or dipyridylamine ligands are present, they bind Tc generating almost invariably the fac-isomer thus forcing the monoanionic ligands to become reciprocally cis-positioned, except for $\mathrm{TcNCl}_{2}$ (PNP1) [59], which instead gives the mer-form (with the monoanionic ligands again in mutual cis position).

The trans distance, $\mathrm{dTc} \equiv \mathrm{N}$ and $\Delta \mathrm{Tc}$ parameters of both LS and HS six-coordinated compounds demonstrate a strong trans-labilizing effect. Examination of the metrical data of both HS and LS complexes show only limited differences among these two subgroups. However, when translating this information to the RP domain, the common feature is that the position trans to nitride is poorly exposed to the risk of exchanging with competing ligands in vitro and in vivo. Thus, the chemical identity of the complexes can be preserved as well as their kinetic stability. To support these statements, a remarkably high in vitro and in vivo stability and negligible interaction with serum proteins were proved for a number of different $\left[{ }^{99 \mathrm{~m}} \mathrm{Tc}\right] \mathrm{TcN}$ complexes comprising those with intermediate coordination number $(5,6)$ such as $[\mathrm{TcN}(\mathrm{L})(\mathrm{PN}(\mathrm{R}) \mathrm{P})]^{0 /+}$ (vide infra). 


\section{3. $T c(V)$ Complexes of Intermediate Coordination Number}

The $\mathrm{Tc}(\mathrm{V})$ complexes with intermediate C.N. are reported in Table 3. They represent an important class of nitrido complexes showing uncommon reactivity properties that has been exploited in recent years in RP applications as an interesting paradigm of synthesis for introducing biologically active fragments in nitrido derivatives (vide infra) [64,65,72,73].

The C.N. of these species can be either 5 or 6 , and it is not clearly defined, because the sixth coordination site trans to the $\mathrm{Tc} \equiv \mathrm{N}$ unit is unquestionably engaged, but the strength of the metal-donor interaction is weaker than that observed for the ordinary six-coordinated compounds (see the Tc- $X$ trans distance for molecules reported in Table 3). Likewise, the $\mathrm{N} \equiv \mathrm{Tc}-\mathrm{X}$ trans-angle varies between 154.7 and $179.4^{\circ}$ (mean of $166.1^{\circ}$ ), a value narrower than that found in more distorted oc LS six-coordinated species. By evaluating the $\tau, \chi, \theta_{1}$ and $\theta_{2}$ indexes it comes out that the coordination geometry is $s p$ (if considering $\mathrm{T}_{\mathrm{c}}$ as five-coordinated) or distorted $o c$ (regarding $\mathrm{T}_{\mathrm{c}}$ as six-coordinated). The mean $\mathrm{T}_{\mathrm{c}} \equiv \mathrm{N}$ bond length is $1.62 \AA$, sitting in the middle of the averages for five-coordinated and six-coordinated (about 1.61 and $1.63 \AA$, respectively). The same applies to the mean Tc displacement from the basal plane, $0.44 \AA$, again intermediate when compared with the mean values for five-coordinated and six-coordinated (about 0.60 and 0.30 , respectively).

With the unique exception of the dianionic $\left[\mathrm{TcN}(\mathrm{CN})_{4} \mathrm{py}\right]^{2-}$, these compounds are either neutral or cationic and are characterized by the presence of a neutral bis-phosphine ligand incorporating at least a heteroatom $(\mathrm{N}, \mathrm{O})$ in the backbone chain among the two P donors. These features, combined with an appropriate $\mathrm{P}^{\wedge} \mathrm{P}$ distance (at least a five-membered chain including the heteroatom), drive the mono-substitution of the PXP at the $[\mathrm{Tc} \equiv \mathrm{N}]^{2+}$ core, yielding the formation of neutral species of the type $\left[\mathrm{TcNCl}_{2}(\mathrm{PXP})\right](\mathrm{PXP}=\mathrm{POOP}, \mathrm{PN}(\mathrm{Pr}) \mathrm{P}, \mathrm{POP})$ (Figure 8) [63-65]. In this situation, PXP virtually acts as a tridentate ligand by placing the two phosphorus atoms in a reciprocal trans- or cis- position and the heteroatom invariably trans to the $\mathrm{T} c \equiv \mathrm{N}$ core, generating an expansion of the coordination sphere from $s p$ (or $t b p$ ) into pseudo-octahedral (pseudo-oc) geometry, unlike what was observed for PNP1 and PSP derivatives, in which the metal is clearly six-coordinated. For these pseudo-oc $\left[\mathrm{TcNCl}_{2}(\mathrm{PXP})\right]$ species, such additional interaction plays a crucial role in providing a further stabilization of the compounds $[59,65]$.

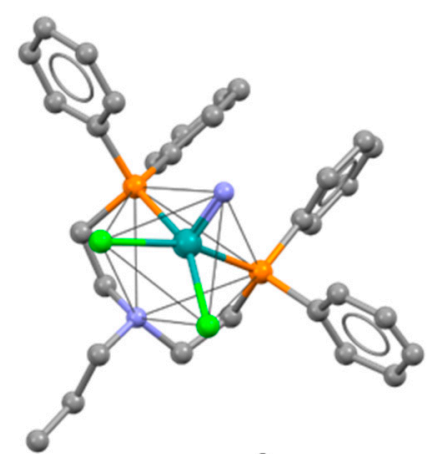

A

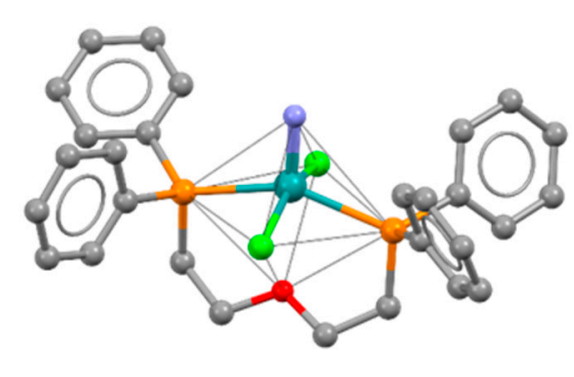

B

Figure 8. Pseudo-oc $\left[\mathrm{TcNCl}_{2}(\mathrm{PXP})\right]$ species. (A) $\left[\mathrm{TcNCl}_{2}(\mathrm{PN}(\mathrm{Pr}) \mathrm{P})\right] ;(\mathbf{B})\left[\mathrm{TcNCl}_{2}(\mathrm{POP})\right]$.

According to this configuration, three different isomeric forms become accessible and have been characterized: fac, cis; mer, cis; mer, trans (Figure 9). The stereochemistry of these compounds is driven by the chemical nature and nucleophilicity of the bis-phosphine heteroatom. Thus, PNP1, which incorporates a secondary amino group in the ligand backbone, only yields the mer, cis isomer (vide supra), whereas $f a c$, cis isomers have been isolated, as the kinetic product, for all the other PXP. Notably, a facial versus meridional isomer conversion was observed for both POP and PSP-containing complexes with the isomerization rate depending on the nature of $\mathrm{X}$. This switch does not occur in the case of $f a c-$-cis $\left[\mathrm{TcNCl}_{2}(\mathrm{PN}(\mathrm{R}) \mathrm{P})\right][59,64,65]$. 


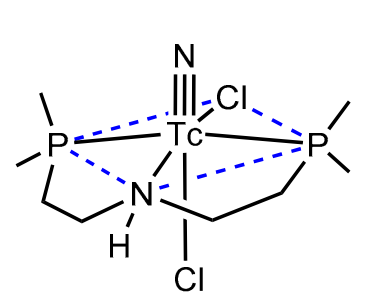

mer, cis

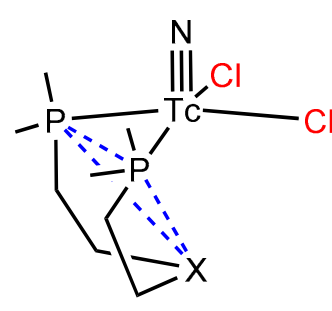

fac, cis

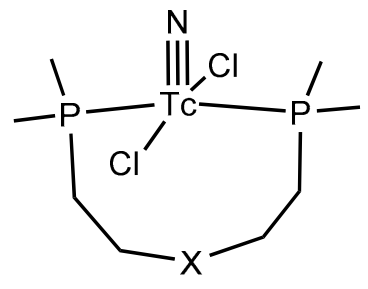

mer, trans

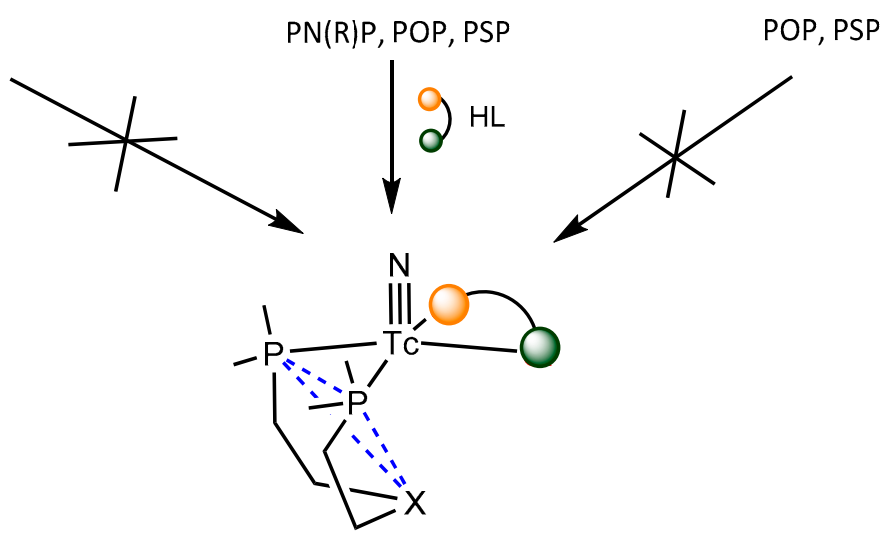

fac, cis

PN(R)P, POP, PSP

Figure 9. Stereochemistry of the various $\left[\mathrm{TcNCl}_{2}(\mathrm{PXP})\right]$ species, along with their reactivity versus HL ligands.

The $f a c, c i s-\left[\mathrm{TcNCl}_{2}(\mathrm{PXP})\right]$ species are activated intermediates that readily undergo exchange reactions by substitution of the geometrically prone, electron-depleted chloride donors with selected bidentate nucleophilic ligands $\left(\mathrm{H}_{2} \mathrm{~L} / \mathrm{HL}\right)$, to generate heteroleptic compounds of the type $[\mathrm{TcN}(\mathrm{L})(\mathrm{PN}(\mathrm{R}) \mathrm{P})]^{0 /+}$. Examples are the monocationic compounds $[\mathrm{TcN}(\mathrm{Me}-\mathrm{dtcz})(\mathrm{POP})]^{+}$and $[\mathrm{TcN}(\mathrm{Me}-\mathrm{dtcz})(\mathrm{PN}(\mathrm{etOMe}) \mathrm{P})]^{+}$, where the two halides are replaced by a chelating monoanionic dithiocarbazate ligand [59,65]; mer, cis and mer, trans isomers do not undergo to the same reaction. Possible explanations are that halides adopting a cis configuration taking an equatorial and an axial position are much less labile; besides, as suggested by DFT calculations, a facial coordination of the $\mathrm{PN}(\mathrm{R}) \mathrm{P}$ ligand minimize the steric constraints of the spacer and also increases the efficiency of $\mathrm{N} \rightarrow \mathrm{Tc}$ interaction [65]. In addition, in fac, cis-[ $\left.\mathrm{TcNCl}_{2}(\mathrm{PN}(\mathrm{R}) \mathrm{P})\right]$ complex, the $\mathrm{Cl} p$ states largely participate to the HOMO, whereas no significant contribution from the $\mathrm{P}$ orbitals is found. This implies the greater lability of the Tc-Cl bonds compared to the Tc-P ones, actually in perfect agreement with the experimental evidence that $\mathrm{Cl}$ can be easily replaced by relevant ligands, meanwhile the $[\mathrm{TcN}(\mathrm{PN}(\mathrm{R}) \mathrm{P})]^{2+}$ moiety remains intact [65].

\section{4. $T c(V I)$ Complexes}

Finally, the few (4) existing $\mathrm{Tc}(\mathrm{VI})$ complexes are almost all monoanionic, with a basal plane defined by four halide ions and an almost regular $s p$ or $o c$ geometry. The only neutral compound is $m e r-\mathrm{TcNCl}_{3}$ (bipy) [69], a distorted oc entity, where the position trans to the nitride is occupied by one of the nitrogen atoms of bipy. The $\mathrm{N} \equiv \mathrm{Tc}-\mathrm{N}$ trans-angle deviates appreciably, as expected, from $180^{\circ}$. Instead, the Tc-N trans-distance, $2.371 \AA$, is shorter than those seen in $o c \mathrm{Tc}(\mathrm{V})$ compounds. Accordingly, the $\mathrm{Tc} \equiv \mathrm{N}$ bond length widens to $1.669 \AA$ which is the third longest value found in the complexes investigated in this work. 


\section{Nitrido Technetium-99m Core in Radiopharmaceutical Applications}

It is clear from the above that $[\mathrm{Tc} \equiv \mathrm{N}]^{2+}$ core exhibits an elegant and predictable chemistry, characterized by different structural arrangements whose formation is sharply controlled by the chemical nature of the coordinating ligand. This variety has been used to develop different classes of radio-compounds suitable in RP applications both as perfusion and target specific agents.

\subsection{Preparation of Nitrido Technetium-99m Radiopharmaceuticals}

The $\left[{ }^{99 \mathrm{~m}} \mathrm{Tc}\right] \mathrm{NaTcO}_{4}$ is the most stable chemical form of this element in aqueous solution and represents the starting material for preparation of all [ $\left.{ }^{99 \mathrm{~m}} \mathrm{Tc}\right] \mathrm{Tc}-\mathrm{RP}$. In all cases, the synthesis requires the reduction of the tetraoxo anion by a pertinent reducing agent or by the combination of reducing agents in the presence of an appropriate coordinating ligand or a combination of ligands able to stabilize the metal in a requested oxidation state, according to the reaction sketched below:

$$
\left[{ }^{99 \mathrm{~m}} \mathrm{Tc}\right] \mathrm{NaTcO}_{4}+\mathrm{R}+\mathrm{L} \rightarrow\left[{ }^{99 \mathrm{~m}} \mathrm{Tc}\right] \mathrm{Tc}-\mathrm{L}_{\mathrm{n}}
$$

where $\mathrm{R}=$ reducing agent; $\mathrm{L}=$ coordinating ligand; $n=$ integer number.

Unlike the preparation of metal oxo-complexes, in which after the reduction of $\left[{ }^{99 \mathrm{~m}} \mathrm{Tc}\right] \mathrm{NaTcO}_{4}$ in aqueous solution a residual oxygen atom remains bound to the metal, the formation of the metal nitrido group requires the reaction of the pertechnetate with a donor of nitrido nitrogen atoms $\left[\mathrm{N}^{3-}\right]$ in presence of the reducing agent.

In this regard, the first attempt to prepare a Tc-nitrido compound at tracer level has been reported by Baldas and Bonnyman $[23,74,75]$. The method was based on the reaction of the tetraoxo anion with $\mathrm{NaN}_{3}$, a nitrido nitrogen donor, in presence of concentrate $\mathrm{HCl}$, at reflux temperature. The reaction yielded the intermediate species $\left[{ }^{99 \mathrm{~m}} \mathrm{Tc}\right]\left[\mathrm{TcNCl}_{4}\right]^{-}$, which after the addition of a suitable coordinating ligand was converted to the final [ $\left.{ }^{99 \mathrm{~m}} \mathrm{Tc}\right] \mathrm{TcN}-\mathrm{RP}$, through a reduction-substitution reaction. However, the method asks for an intricate multistep procedure involving the evaporation, at reduced pressure, both of the aqueous solution of the pertechnetate before the addition of the reagents and of the solution containing the intermediate species $\left[{ }^{99 \mathrm{~m}} \mathrm{Tc}\right]\left[\mathrm{TcNCl}_{4}\right]^{-}$before the addition of the coordinating ligand. Such a reaction scheme makes it difficult to meet the requirements for nuclear medicinal applications.

An improved synthetic approach for this class of complexes, at tracer level and in relatively mild conditions, was described by Duatti and coworkers [76] few years later. In this procedure, $\left[{ }^{99 \mathrm{~m}} \mathrm{Tc}\right] \mathrm{NaTcO}_{4}$ reacted in ethanol under acidic conditions with $\mathrm{PPh}_{3}$ and $\mathrm{H}_{2}$ saldtcz, a Schiff base derivative of the dithiocarbazic acid, to generate quantitatively the complex [ $\left.{ }^{99 \mathrm{~m}} \mathrm{Tc}\right]\left[\mathrm{TcN}\left(\right.\right.$ saldtcz) $\left.\left(\mathrm{PPh}_{3}\right)\right]$ (Figure 10). Its chemical identity was determined by thin layer chromatography by comparing the $\mathrm{R}_{\mathrm{f}}$ value of the $\left[{ }^{99 \mathrm{~m}} \mathrm{Tc}\right] \mathrm{Tc}-$ species with that of the corresponding compound produced in macroscopic amounts by using the long-lived isotope ${ }^{99} \mathrm{Tc}$. The $\left[{ }^{99 \mathrm{~m}} \mathrm{Tc}\right]\left[\mathrm{TcN}(\mathrm{saldtcz})\left(\mathrm{PPh}_{3}\right)\right]$ is a $s p$ five-coordinated $\mathrm{Tc}(\mathrm{V})-$ complex, characterized by a terminal $\mathrm{Tc} \equiv \mathrm{N}$ multiple bond joined to a $\mathrm{PPh}_{3}$ and to a deprotonated tridentate saldtcz ${ }^{2-}$ ligand. 

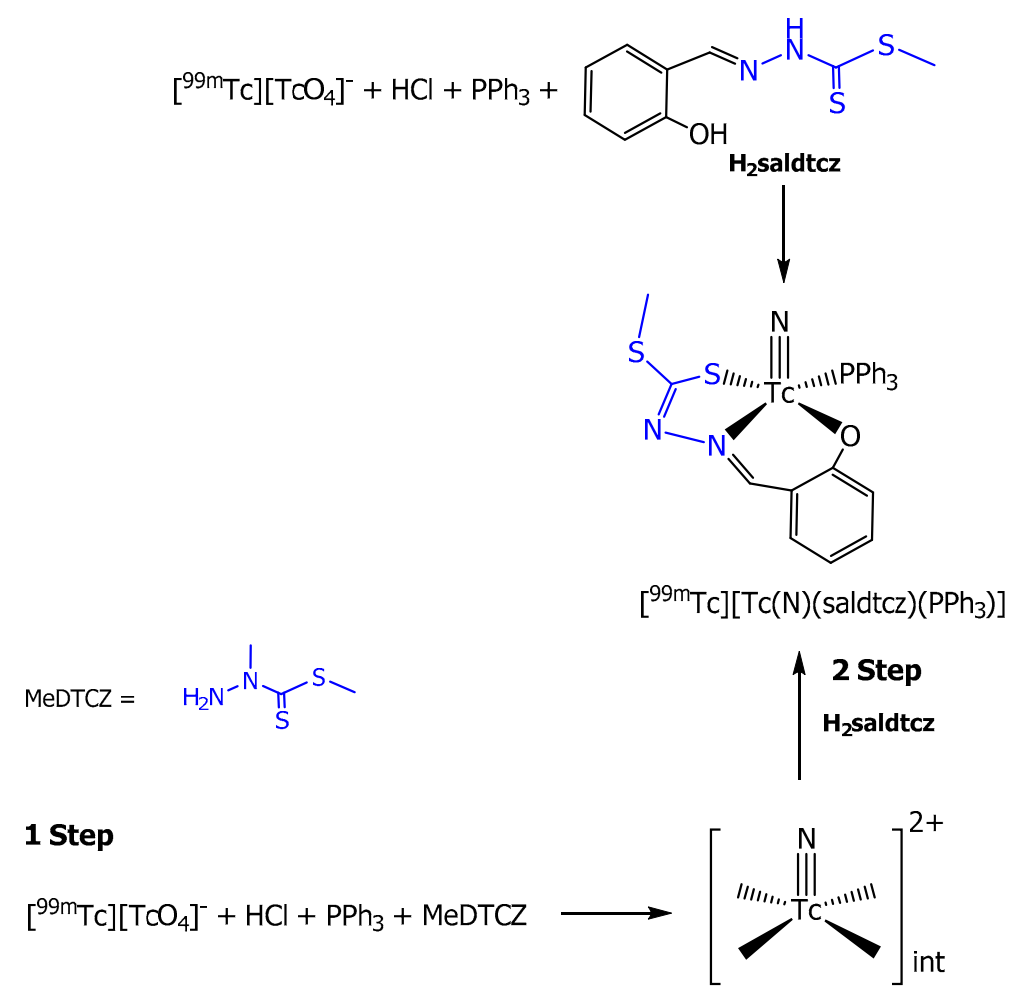

Figure 10. Reaction scheme for the synthesis of the $\left[{ }^{99 \mathrm{~m}} \mathrm{Tc}\right]\left[\mathrm{TcN}(\right.$ saldtcz $\left.)\left(\mathrm{PPh}_{3}\right)\right]$ complex.

In this reaction, $\mathrm{PPh}_{3}$, an oxygen atom acceptor, acts as reducing agent promoting the transfer of the oxygen atoms from the metal center to the $\mathrm{P}$; meanwhile, $\mathrm{H}_{2}$ saldtcz serves both as a coordinating ligand, bonding the metal trough the $\mathrm{O}^{\wedge} \mathrm{NS}^{\wedge}$ atom set, and as a donor of $\mathrm{N}^{3-}$ atoms to afford the $\mathrm{Tc} \equiv \mathrm{N}$ group. The $\mathrm{N}^{3-}$ donor ability of $\mathrm{H}_{2}$ saldtcz was attributed to DTCZ moiety. The performance of the latter as an $\mathrm{N}^{3-}$ donor was confirmed by splitting the above described reaction in two steps (Figure 10, bottom). In the first one, the tetraoxo anion directly reacted with MeDTCZ; the addition of the tridentate $\mathrm{H}_{2}$ saldtcz ligand followed in the second one. Thus, upon the addition of $\left[{ }^{99} \mathrm{~m} \mathrm{Tc}\right] \mathrm{NaTcO}_{4}$, a mixture of different intermediate species, $[\mathrm{Tc} \equiv \mathrm{N}]^{2+}{ }_{\text {int }}$, was obtained; the subsequent reaction of $[\mathrm{Tc} \equiv \mathrm{N}]^{2+}{ }_{\text {int }}$ with $\mathrm{H}_{2}$ saldtcz gave the formation of $\left[{ }^{99 \mathrm{~m}} \mathrm{Tc}\right]\left[\mathrm{TcN}(\operatorname{saldtcz})\left(\mathrm{PPh}_{3}\right)\right]$ in high yield, demonstrating that all the species incorporated the $\mathrm{T} c \equiv \mathrm{N}$ core.

Quantitative conversion of the mixture into a single product was also readily accomplished through the reaction with dithiocarbamate ligands $\mathrm{Na}\left[\mathrm{S}(\mathrm{S}=) \mathrm{C}-\mathrm{NR}_{2}\right](\mathrm{R}=$ organic functional groups) to yield the bis-substituted nitrido $\mathrm{Tc}(\mathrm{V})$ species [ $\left.{ }^{99 \mathrm{~m}} \mathrm{Tc}\right]\left[\mathrm{TcN}\left(\mathrm{S}_{2} \mathrm{CNR}_{2}\right)_{2}\right][77,78]$.

The proposed method overcame all the limitations associated with the Baldas' procedure, allowing the preparation of $\left[{ }^{99 \mathrm{~m}} \mathrm{Tc}\right] \mathrm{TcN}-\mathrm{RPs}$ in carefully controlled conditions. Besides, these findings clearly showed that the chemistry was perfectly feasible at tracer level, paving the way to a further exploration of this class of complexes in RP fields.

Subsequently, different compounds containing the hydrazine-like motif $>\mathrm{N}-\mathrm{N}<$ were tested as $\mathrm{N}^{3-}$ donors in the reaction with the pertechnetate [77]; some of them are reported in Table 4. 
Table 4. Yield of formation of the complexes using various nitrido donating ligands [79].

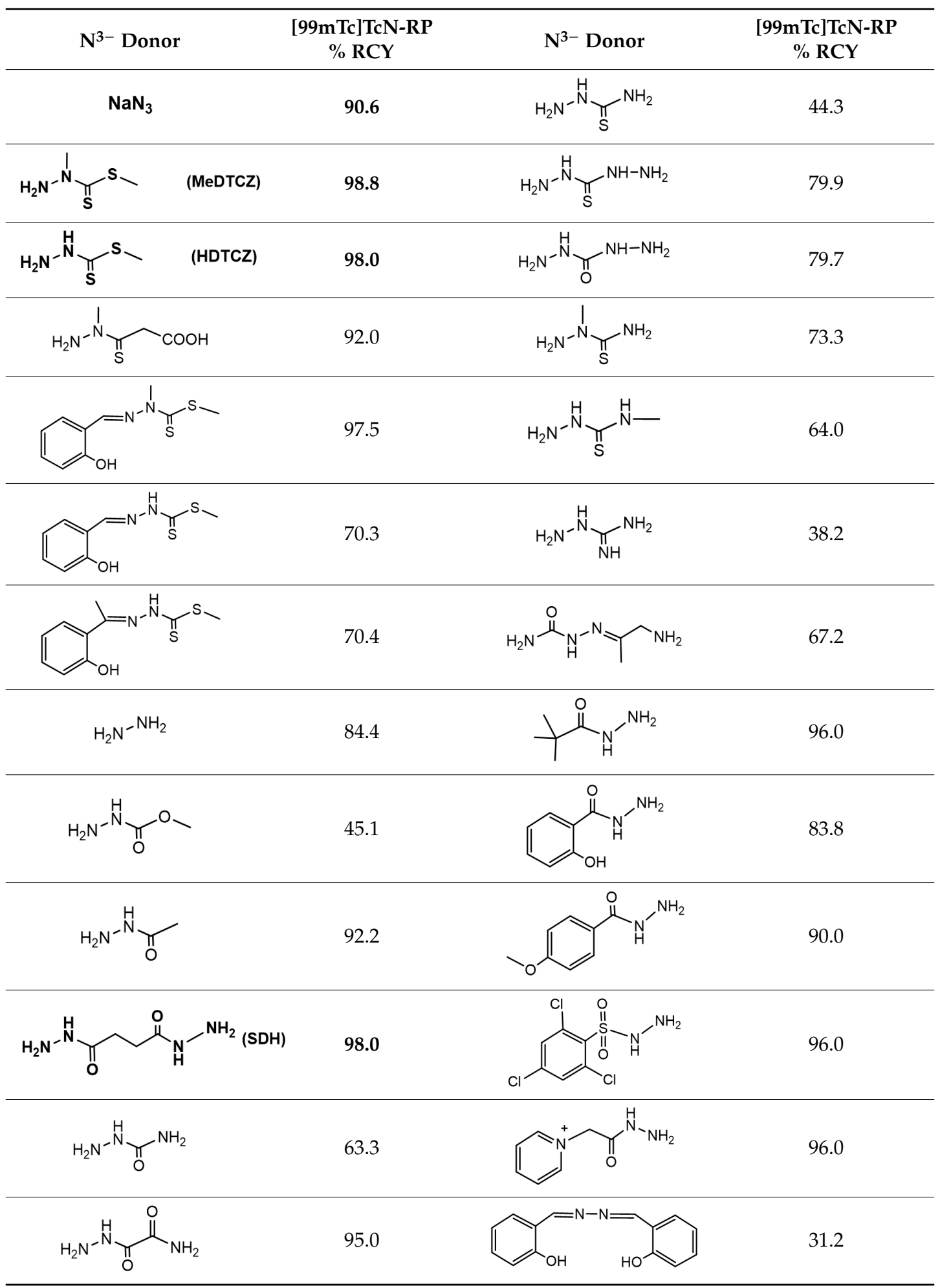

Among these, MeDTCZ and HDTCZ were found to be the most efficient $\mathrm{N}^{3-}$ donors [80]; indeed, only micrograms amount $(10-50 \mu \mathrm{g})$ are sufficient to generate the $\mathrm{M} \equiv \mathrm{N}$ core $\left(\mathrm{M}={ }^{99 \mathrm{~m}} \mathrm{Tc} ;{ }^{188} \mathrm{Re}\right)$. Unfortunately, its very powerful donating nature is counterbalanced by its prominent chelating strength (NH^S atom set). On the one hand, the latter ability contributes to stabilize the metal center $[77,80,81]$, on the other it becomes a disadvantage, in particular when an exchange reaction with another ligand has to be carried out to obtain the desired final complex in high yield and high specific activities $[80,81]$. 
Thus, succinic dihydrazide (SDH) was selected owing to its water solubility, low toxicity, and lack of coordinating properties as a convenient source of $\mathrm{N}^{3-}$ atoms for the preparation of the $\left[{ }^{99} \mathrm{~m} \mathrm{Tc}\right][\mathrm{Tc} \equiv \mathrm{N}]$ core as a freeze-dry pharmaceutical kit. Up to now, a suitable instant kit includes $\mathrm{SDH}, \mathrm{SnCl}_{2}$ as reducing agent, DPTA or EDTA as $\mathrm{Sn}^{2+}$ complexing agent, and phosphate buffer (PB) as $\mathrm{pH}$ controller (Figure 11).

\section{RADIOSYNTHESIS}

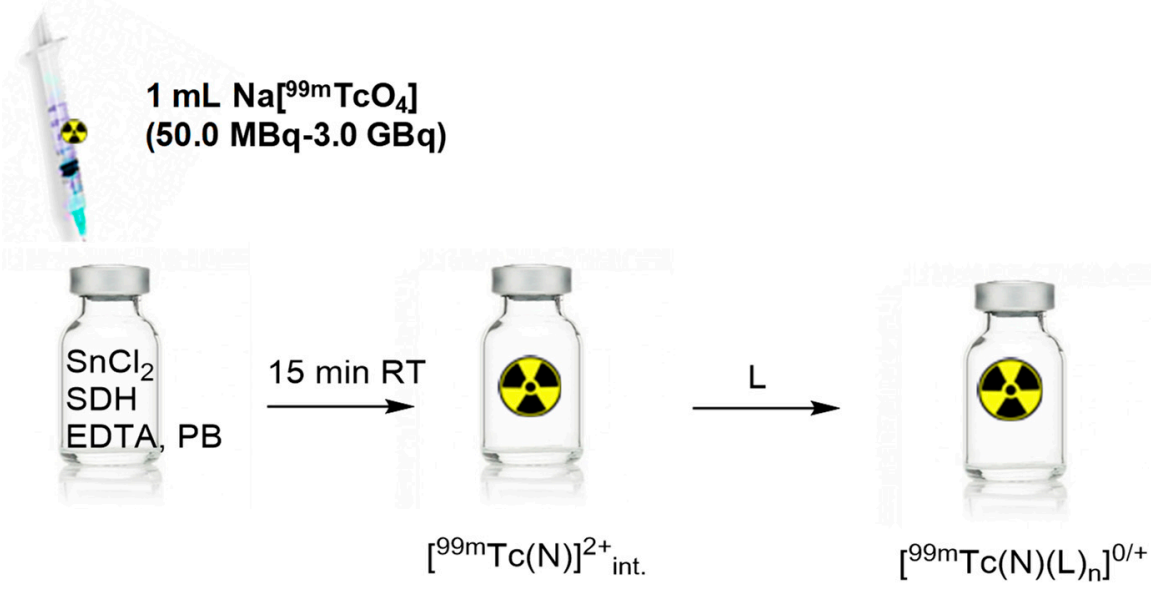

Figure 11. Preparation of $\left[{ }^{99 \mathrm{~m}} \mathrm{Tc}\right][\mathrm{Tc} \equiv \mathrm{N}]-\mathrm{RPs},(\mathrm{L}=$ selected coordinating ligand $)$.

Upon simple addition of a freshly generator-eluted pertechnetate solution to the vial containing the above mentioned reagents, the formation of the $\left[{ }^{99 \mathrm{~m}} \mathrm{Tc}\right] \mathrm{Tc} \equiv \mathrm{N}$ group takes place within $15 \mathrm{~min}$ at room temperature, and a mixture of intermediate compounds, all characterized by the $\left[{ }^{99 \mathrm{~m}} \mathrm{Tc}\right][\mathrm{Tc} \equiv \mathrm{N}]^{2+}$ core, is achieved in sterile and pyrogen-free conditions. The exact chemical nature of these $\left.{ }^{99 \mathrm{~m}} \mathrm{Tc}\right][\mathrm{Tc} \equiv \mathrm{N}]^{2+}{ }_{\text {int }}$ intermediates has not yet been fully established. However, the quantitative incorporation of the $\left[{ }^{99 m} \mathrm{Tc}\right][\mathrm{Tc} \equiv \mathrm{N}]^{2+}$ core into the final complex can be obtained in a second step, by adding the pertinent coordinating ligand or a combination of ligands to the $\left[{ }^{99 m} \mathrm{Tc}\right][\mathrm{Tc} \equiv \mathrm{N}]^{2+}$ int mixture.

Notably, at no-carrier added level, the $\left[{ }^{99 m} \mathrm{Tc}\right][\mathrm{Tc} \equiv \mathrm{N}]^{2+}$ core is stable after formation under a wide range of experimental conditions, and it is able to confer a high thermodynamic and kinetic stability to the complex where it is present, as well as resistance to redox processes. The chemistry is efficiently transferred to Re-188 [82]. In spite of this, the application of this moiety to the RP use still remains poorly investigated.

\subsection{Homoleptic Compounds as Myocardial Perfusion Imaging Agents}

In past years, a number of ${ }^{99 \mathrm{~m}} \mathrm{Tc}$-labeled nitride compounds potentially useful for imaging of the most important organs have been found, and a series of both homoleptic and heteroleptic $\mathrm{Tc}(\mathrm{V})$ nitrido complexes proved to be particularly useful for heart imaging.

Myocardial nuclear perfusion imaging (MPI) by [ $\left.{ }^{99 \mathrm{~m}} \mathrm{Tc}\right] \mathrm{Tc}-\mathrm{RPs}$ remains the most extensively used non-invasive diagnostic and prognostic tool for coronary artery disease (CAD) [83], utilized to determine areas of reversible ischemia, to characterize infarcted tissues, and to assess left ventricular function [84].

In this connection, the homoleptic bis-substituted dithiocarbamate nitrido $\mathrm{Tc}(\mathrm{V})$ complexes of general formula [ $\left.{ }^{99 \mathrm{~m}} \mathrm{Tc}\right]\left[\mathrm{TcN}\left(\mathrm{S}_{2} \mathrm{CNR}_{2}\right)_{2}\right]$ demonstrated to be an important class of MPI agents. These neutral complexes are characterized by an $s p$ arrangement, wherein two identical monoanionic dithiocarbamate ligands coordinate the metal center through the sulfur atoms occupying the four positions in the basal plane of the pyramid, whereas the nitrido ligand remains at the apical site $[78,85]$. The variation of the chemical nature of the substituents bound to the $\mathrm{S}_{2} \mathrm{CN}$ unit allowed to obtain a 
series of perfusion tracers characterized by different pharmacokinetic properties; both heart uptake, and the activity residence time in the myocardial tissue were highly variable, the latter ranging from few minutes to hours.

The $\left[{ }^{99 \mathrm{~m}} \mathrm{Tc}\right]\left[\mathrm{TcN}(\mathrm{NOEt})_{2}\right]$ (bis(N-ethoxy,N-ethyldithiocarbamato)nitrido-Tc $\left.(\mathrm{V})\right)$, named $\mathrm{TcN}-\mathrm{NOET}$, is the most representative member of this class of neutral and lipophilic $\mathrm{Tc}(\mathrm{V})$ nitrido complexes [85]. The TcN-NOET was the first example of a neutral compound with prolonged heart uptake. Owing to its peculiar imaging properties, it was selected for extensive clinical evaluation in patients. Biodistribution studies in healthy volunteers highlighted that the heart uptake of TcN-NOET is remarkable, approaching $4 \%$ of injected activity at 5 min post injection; the washout of the activity from the myocardial tissue is slow, with a half-life of approximately $3 \mathrm{~h}$ [86], thus showing imaging properties and kinetic behavior much closer to those of ${ }^{201} \mathrm{Tl}$ rather than to other ${ }^{99 \mathrm{~m}} \mathrm{Tc}$-complexes.

These similarities include: high first pass extraction ranging from $80 \%$ to 90\% [87-89]; good correlation with coronary blood flow, as it has been established that the myocardial uptake is proportional with the heart blood flow at low and medium flux rates, becoming approximately $80 \%$ at higher fluxes $[87,90]$ and with redistribution $[87,91,92]$. This latter property is correlated to the absence of specific intracellular binding $[93,94]$ of the agent and to its relatively high level into circulating blood which enables it to freely move across viable heart areas filled with different concentration activity and to slowly diffuse from high activity toward low activity regions such as normally perfused myocardial tissue versus ischemic areas. These abilities make TcN-NOET unique in allowing the same exploration as ${ }^{201} \mathrm{Tl}$ stress redistribution but with a more favorable dosimetry [95]. Some disadvantages are the transient lungs uptake of the tracer during the first few minutes post-injection and its persistent liver localization. Notwithstanding experimental studies indicated that the neutral and lipophilic properties of TcN-NOET make it a promising pure myocardial blood flow tracer and that this agent completed phase III clinical trials in the United States and Europe, it has not been approved for clinical use.

A relevant feature of the use of the $\left[{ }^{99 \mathrm{~m}} \mathrm{Tc}\right]\left[\mathrm{TcN}\left(\mathrm{S}_{2} \mathrm{CNR}_{2}\right)_{2}\right]$ complexes is the opportunity to achieve significant changes of their biodistribution profile by modifying the dithiocarbamate ligand. For instance, homoleptic [ $\left.{ }^{99 \mathrm{~m}} \mathrm{Tc}\right]\left[\mathrm{TcN}\left(\mathrm{S}_{2} \mathrm{CNR}_{2}\right)_{2}\right]$ complexes where the $\mathrm{S}_{2} \mathrm{CNR}_{2}$ group is derived from primary amines as well as few secondary amines carrying alkyl and ester groups, showed to cross the blood-brain barrier, suggesting a possible application also in brain perfusion imaging [96].

Another class of HS homoleptic nitrido $\mathrm{Tc}(\mathrm{V})$ complexes showing good heart uptake is represented by a series of five-coordinated [ $\left.{ }^{99 \mathrm{~m}} \mathrm{Tc}\right]\left[\mathrm{TcN}\left(\mathrm{R}_{2} \mathrm{PS}\right)_{2}\right]$ compounds, where $\mathrm{R}_{2} \mathrm{PS}$ is the deprotonated form of a phosphinothiol ligand ( $\mathrm{R}_{2} \mathrm{PSH} ; \mathrm{R}=$ phenyl, alkyl, alkoxy-alkyl) [22,97,98]. Structural characterization showed that the phosphinothiol ligands are bound to the metal center through the neutral phosphorus and the thiolate sulfur atoms in an uncommon $t b p$ geometry, where the two $P$ atoms occupy the trans axial positions and the two $S$ atoms lie on the equatorial plane, along with the nitrido nitrogen [22]. Biodistribution studies carried out on rats showed for this class of neutral compounds high initial myocardial uptake, apparently driven by their lipophilic character. The heart uptake and the elimination kinetics from the tissue were dependent from the nature of the $\mathrm{R}$ lateral group placed on the P atom of the ligands, ranging also in this case from few minutes to few hours [97]. An interesting feature for this class of complexes comes from the relatively fast washout from blood and from non-target organs such as lungs and liver exhibited by the less lipophilic tracers, especially those including methyl or ether side groups on the coordinated phosphinothiol ligands [97].

Radiosyntheses of [ $\left.{ }^{99 \mathrm{~m}} \mathrm{Tc}\right]\left[\mathrm{TcN}\left(\mathrm{R}_{2} \mathrm{PS}\right)_{2}\right]$ were performed in two steps, according to the reaction sketched in Figure 11 [97,98]. When the first step was carried out by reacting fresh eluted pertechnetate with $\mathrm{SDH}$ and $\mathrm{PPh}_{3}$ as reducing agent in acidic media, the generation of monosubstituted species of the type $\left[{ }^{99 \mathrm{~m}} \mathrm{Tc}\right]\left[\mathrm{TcNCl}\left(\mathrm{R}_{2} \mathrm{PS}\right)\left(\mathrm{PPh}_{3}\right)\right]$ was observed upon addition of the pertinent $\mathrm{R}_{2} \mathrm{PSH}$ ligand $\left(\mathrm{R}=\mathrm{C}_{6} \mathrm{H}_{11}, \mathrm{CH}\left(\mathrm{CH}_{3}\right)_{2}, \mathrm{CH}_{2} \mathrm{CH}\left(\mathrm{CH}_{3}\right)_{2}\right)$ [98]. In this case, the coordination geometry around Tc is intermediate between $s p$ and $t b p$. In the tbp description, the nitrido group, the chloride and the thiolate sulfur atoms occupy the equatorial plane, while the two phosphine phosphorus atoms are at the apexes of the bypyramid [21,41]. 
In these complexes, the $\left[{ }^{99 \mathrm{~m} / 99} \mathrm{Tc}\right]\left[\mathrm{TcN}\left(\mathrm{R}_{2} \mathrm{PS}\right)\right]^{+}$moiety is substitution-inert, meanwhile the monodentate $\mathrm{Cl}$ and $\mathrm{PPh}_{3}$ are substitution-labile and can be quickly replaced by selected bidentate $\left(\mathrm{S}^{\wedge} \mathrm{Y}\right)$ ligands to afford heteroleptic $\left[{ }^{99 \mathrm{~m} / 99} \mathrm{Tc}\right]\left[\mathrm{TcN}\left(\mathrm{R}_{2} \mathrm{PS}\right)\left(\mathrm{S}^{\wedge} \mathrm{Y}\right]\right.$ complexes. Mononegative $\left[\mathrm{S}^{\wedge} \mathrm{S}\right]^{-}$chelators, such as DTC, exhibit high selectivity in displacing the monodentate ligands, allowing the preparation of different mixed-ligand compounds $\left[{ }^{99 m / 99} \mathrm{Tc}\right]\left[\mathrm{TcN}\left(\mathrm{R}_{2} \mathrm{PS}\right)(\mathrm{DTC}]\right.$, in which DTC also carry a bioactive molecule (vide infra) [98,99].

Biodistribution studies of the complexes prove an appreciable initial accumulation in both cerebral and myocardial tissues, followed by a fast washout within $20 \mathrm{~min}$ after injection. In all cases, the blood clearance is rapid, and the activity is removed through the liver and kidneys. Unfortunately, the lack of commercially available functionalized phosphines, whose synthesis requires tedious multistep procedures, is an important hurdle preventing the use of these entities in RP applications.

\subsection{Heteroleptic Compounds as Myocardial Perfusion Imaging Agents}

Over the last decade, a number of heteroleptic monocationic compounds, characterized by the presence of the $\left[{ }^{99} \mathrm{~m} \mathrm{Tc}\right][\mathrm{TcN}(\mathrm{PNP})]$ scaffold, have been investigated as potential MPI agents (MPIAs) [100-105]. The sketches of the most representative complexes are illustrated in Figure 12.

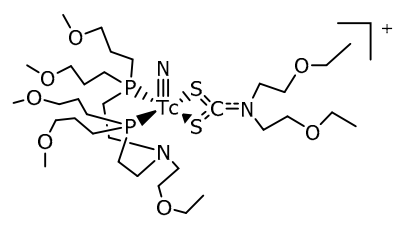

$\left.{ }^{99 \mathrm{~m}} \mathrm{Tc}\right] \mathrm{TcN}-\mathrm{DBODC5}$

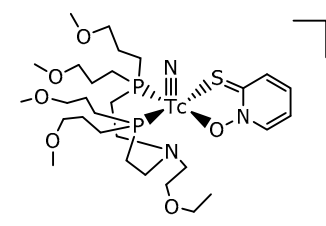

$\left[{ }^{99 \mathrm{~m}} \mathrm{Tc}\right] \mathrm{TCN}-\mathrm{MPO}$

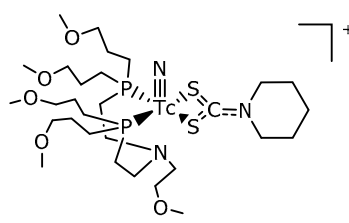

[99m Tc]TCN-PDTC3

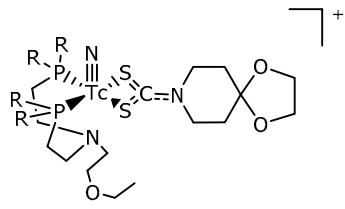

$\left[{ }^{99 m} \mathrm{Tc}\right] \mathrm{TCN}-\mathrm{DASD} 5 \mathrm{R}=-\mathrm{CH}_{2}-\mathrm{CH}_{2}-\mathrm{CH}_{2} \mathrm{OCH}_{3}$ $\left.{ }^{99 \mathrm{~m}} \mathrm{Tc}\right] \mathrm{TCN}-\mathrm{DASD} 7 \mathrm{R}=-\mathrm{CH}_{2}-\mathrm{CH}_{2} \mathrm{OCH}_{3}$

Figure 12. Structures of the most representative [ $\left.{ }^{99 \mathrm{~m}} \mathrm{Tc}\right][\mathrm{TcN}(\mathrm{PNPn})]$-based MPIAs.

The complexes, of general formula $\left[{ }^{99 \mathrm{~m}} \mathrm{Tc}\right][\mathrm{TcN}(\mathrm{L})(\mathrm{PNP})]^{+}$, contain one neutral bis-phosphinoamine ligand and one monoanionic chelate (L), selected among dithiocarbamate derivatives (linear-, alicyclic-, crown ether-dithiocarbamate), a thiomaltol derivative or pyridine-2-thiolate $\mathrm{N}$-oxide (MPO), bound to the same $[\mathrm{Tc} \equiv \mathrm{N}]^{2+}$ core through the two $\mathrm{P}$ atoms and the $\mathrm{S}^{\wedge} \mathrm{Y}$ atom pair $(\mathrm{Y}=\mathrm{S} ; \mathrm{O})$ in a highly distorted $s p$ (or pseudo-oc) geometry [106]. The preparation of these heteroleptic compounds is accomplished in physiological conditions through the simultaneous reaction of the mixture of nitrido precursors (prepared as above) with the PNP and L ligands.

Data from biodistribution studies on rats clearly evidenced, for this class of agents, improved pharmacokinetic profiles with respect to those of commercially available MPIAs ([99m Tc]Tc-Sestamibi, ${ }^{99 \mathrm{~m}} \mathrm{Tc}-\mathrm{MIBI}$; $\left.\left.{ }^{99 \mathrm{~m}} \mathrm{Tc}\right] \mathrm{Tc}-\mathrm{Tetrofosmin},{ }^{99 \mathrm{~m}} \mathrm{Tc}-\mathrm{Tf}\right)$, consisting in a fast high initial and persistent heart uptake, rapid blood clearance and elimination from non-target tissues (Figure 13). 

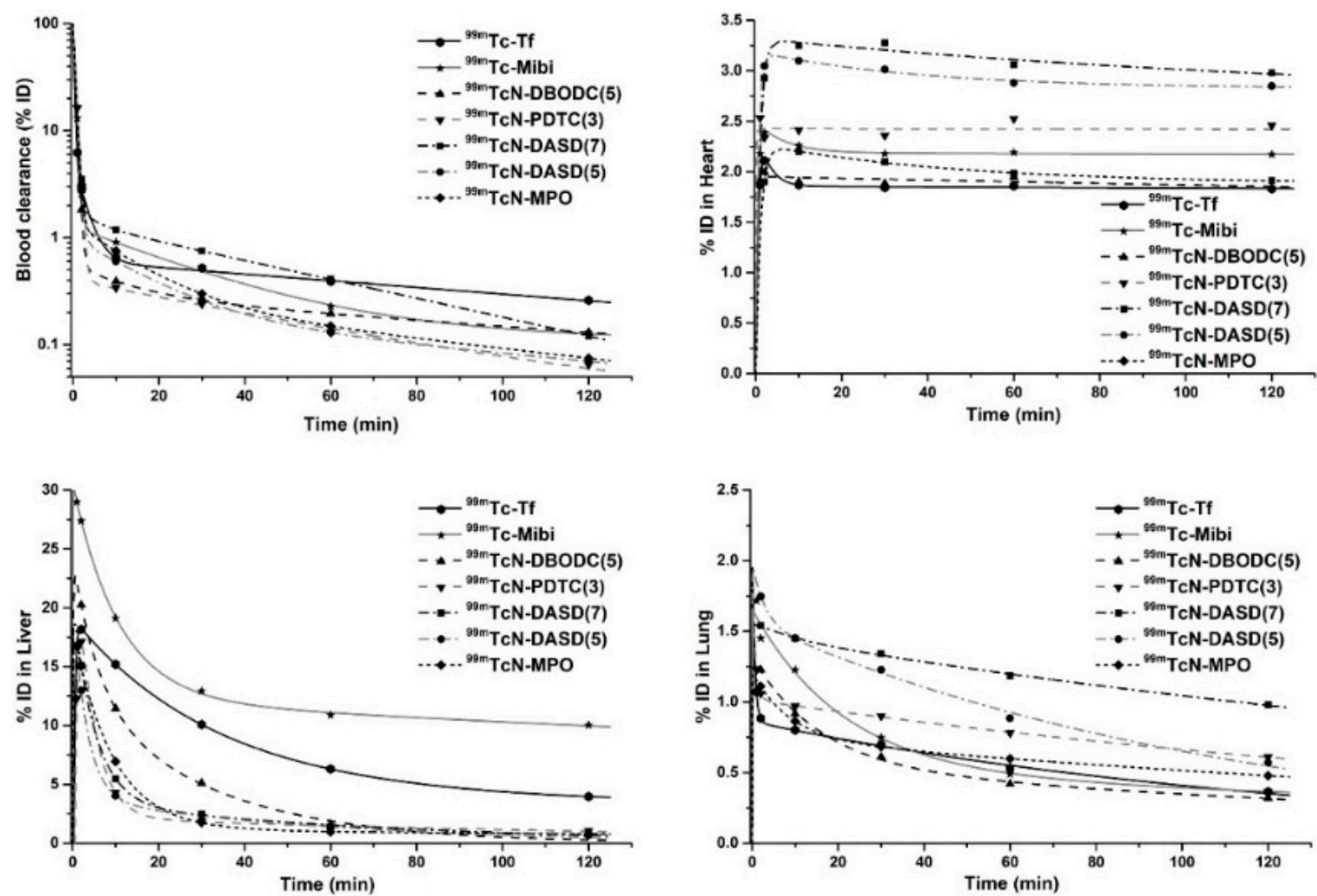

Figure 13. Time-activity curves of $\left[{ }^{99 \mathrm{~m}} \mathrm{Tc}\right][\mathrm{TcN}(\mathrm{L})(\mathrm{PNP})]^{+}$in the main organs compared with those of commercially available MPIAs.

For all these compounds, planar imaging of rats shows early myocardial images without interference from adjacent organ activity (lungs and liver), thus affording, in principle, a high quality of myocardial imaging together with a clinically significant reduction in imaging delay (Figure 14).

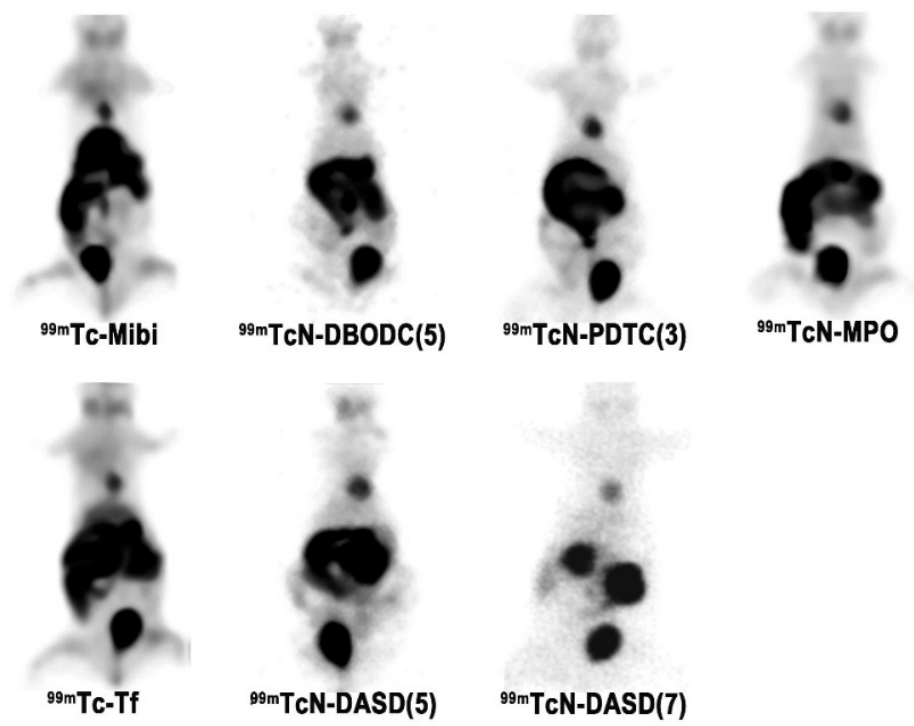

Figure 14. Planar imaging of selected $\left[{ }^{99 \mathrm{~m}} \mathrm{Tc}\right][\mathrm{TcN}(\mathrm{L})(\mathrm{PNP})]^{+}$compounds compared with those of commercially available MPIAs.

The most important feature of the $\left[{ }^{99 \mathrm{~m}} \mathrm{Tc}\right][\mathrm{TcN}(\mathrm{L})(\mathrm{PNP})]^{+}$complexes lies in their heteroleptic nature which enables a fine modulation/tuning of the pharmacokinetics (heart uptake and lung/liver washout) by varying substituents at both the PNP and L ligands [101,103,104]. During the development 
of these mixed-ligand compounds, it has been attested that (i) the use of ether-containing ligands has a positive effect on the bio-kinetic profile of the agents, significantly reducing the liver uptake and improving the hepatic clearance, hence yielding favorable target/background (T/B) ratios [105]; (ii) the length of the ether-containing substituents on the PNP ligand must not exceed five atoms, otherwise the liver uptake and T/B ratios turn back to be unfavorable [101,104]; (iii) the incorporation of an alicyclic dithiocarbamate, instead of a linear one significantly increase the myocardial uptake: $20 \%$ higher at early injection time [103]. Similar results were reported also by Kim et al. using different bidentate ligands, ranging from maltholate to MPO towards the $\left.{ }^{99 \mathrm{~m}} \mathrm{Tc}\right][\mathrm{TcN}(\mathrm{PNP} 5)]$ scaffold $[102,103]$. Both the use of alicyclic dithiocarbamate and the insertion of ether groups on the PNP ligand improve the heart uptake and the imaging properties of the complexes $[104,105]$.

However, the favorable pharmacokinetic properties of $\left[{ }^{99 \mathrm{~m}} \mathrm{Tc}\right][\mathrm{TcN}(\mathrm{L})(\mathrm{PNP})]^{+}$complexes are somehow negatively counterbalanced by their relatively low myocardial first-pass extraction (approximately $60 \%$ ) and minimal redistribution, characteristic of cationic agents as ${ }^{99 \mathrm{~m}} \mathrm{Tc}-\mathrm{MIBI}$ and ${ }^{99 \mathrm{~m}} \mathrm{Tc}-\mathrm{Tf}$. Compounds showing higher extraction, such as neutral $\left[{ }^{99 \mathrm{~m}} \mathrm{Tc}\right] \mathrm{Tc}-$ Teboroxime $(88-91 \%)$ and TcN-NOET ( $\sim 80-90 \%)$, can track blood flow better and over a wider range than tracers having lower first pass extraction. In addition, they are more suitable for a quantitative evaluation of milder flow-limiting coronary stenosis under stress conditions [91,107-112].

Mechanistic studies of some of these $\left[{ }^{99 \mathrm{~m}} \mathrm{Tc}\right][\mathrm{TcN}(\mathrm{L})(\mathrm{PNP})]^{+}$complexes established that their favorable pharmacokinetic profile is due to the combined action of two main biochemical processes [103, $105,113,114]$. The first one is the myocardial uptake, as a result of the build-up of these monocationic agents into mitochondrial structures of myocytes (where they are particularly abundant: $40 \%$ of the total volume of myocytes is occupied by mitochondria), in response to the negative mitochondrial membrane potential. At this stage, the lipophilic character of the compounds modulates their penetration into cellular membrane, whereas their electronic charge being responsible for the mitochondrial uptake/trapping. This process is opposed by the extrusion of the complex from the cells by the P-gp/MRP1 transporters expressed in normal tissues (heart, lungs, etc.) and also in those involved in excretory functions, such as liver and kidney. The actual participation of the P-gp/MRP1 transporters on the rapid liver and tissues excretion of $\left[{ }^{99 \mathrm{~m}} \mathrm{Tc}\right][\mathrm{TcN}(\mathrm{L})(\mathrm{PNP})]^{+}$complexes has been confirmed by both biodistribution and imaging studies carried out in the absence/presence of cyclosporine $\mathrm{A}, \mathrm{a}$ potent P-gp/MRP1 modulator [102,104,113].

The recognition of the complexes by P-gp/MRP1 transporters prompts the fast elimination of the activity from the liver to the intestine promoting the quick lowering of the background activity, which in turn leads to high target-to-non-target ratios. This feature, translated on myocardial imaging, might contribute to reduce the duration of imaging protocols, consenting a more accurate interpretation of the activity in the inferior left ventricular wall.

To date, results from clinical studies are available only for [ $\left.{ }^{99 \mathrm{~m}} \mathrm{Tc}\right][\mathrm{TcN}(\mathrm{DBODC})(\mathrm{PNP} 5)]^{+}$ ([DBODC $=$ bis(N-ethoxyethyl)-dithiocarbamate; PNP5 = bis(dimethoxypropylphosphinoethyl)ethoxyethylamine]), abbreviated to ${ }^{99 \mathrm{~m}} \mathrm{TcN}-\operatorname{DBODC}(5)[115,116]$. Data show that, in spite of the good pharmacokinetics of this agent which allows a better imaging quality and superior clinical value for the detection of CAD over ${ }^{99 \mathrm{~m}} \mathrm{Tc}-\mathrm{MIBI}$, its clinical properties seem to be close to those observed for ${ }^{99 \mathrm{~m}} \mathrm{Tc}-\mathrm{Tf}$, failing to fully reproduce the encouraging experimental results achieved in preclinical studies [115-117]. Thus, in terms of sensitivity, specificity and diagnostic accuracy, the three MPIAs seems to possess similar clinical properties.

\subsection{Labeling of Biologically Active Molecules: Target Specific Compounds}

The development of target specific imaging agents is one of the major challenges in RP chemistry and represents currently the heart of the modern radiopharmaceutical research. In this context, the main problems still to be overcome are related to biochemical and medical issues. In addition, stable and kinetically inert bonding cores have to be developed, preventing metabolic destruction or reorganization of the metal coordination sphere in such compounds. Hence, synthetic approaches 
require precise knowledge of both fundamental and coordination chemistry as well as of redox behavior of the metal bound to the biologically relevant ligand.

Figure 15 shows a series of homoleptic and heteroleptic nitrido $\mathrm{Tc}(\mathrm{V})$ complexes whose chemical properties have been exploited to generate target specific compounds. In all these approaches, the metal coordination site is kept separated from the targeting site of the molecular vector, in order to minimize any possible interference.

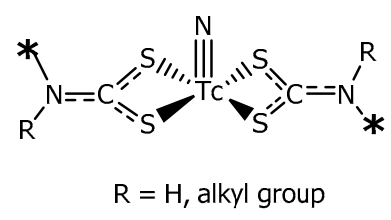

A

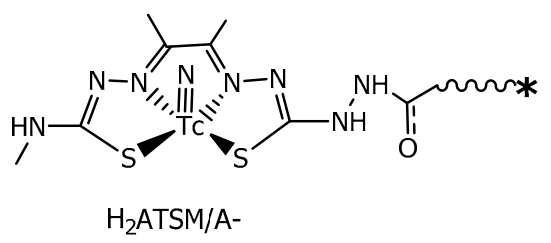

B

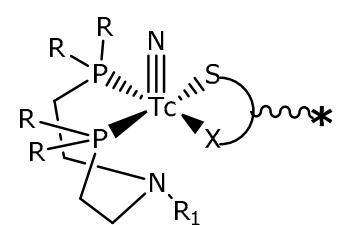

$\mathrm{R}=\mathrm{R} 1$, alkyl or alkoxyalkyl $\mathrm{R}=$ phenyl, alkyl, alkoxyalkyl $\mathrm{R} 1=$ alkyl, alkoxyalkyl

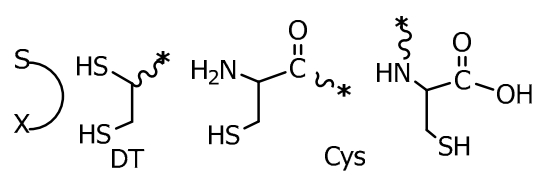

C

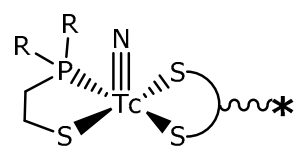

R =Isopropyl;Cyclohexyl<smiles></smiles>
$\mathrm{R}^{\prime}=\mathrm{H}$; Me, Et

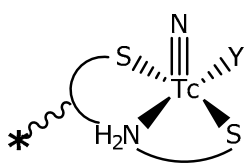

$X=$ Cys-Cys or HDTCZ $\mathrm{Y}=$ monophosphine $\left(\mathrm{PR}_{3}\right)$

\section{$\mathbf{E}$}

\section{D}

$$
\text { * = bioactive group } \quad \sim \sim \sim \text { = spacer }
$$

Figure 15. Schematic drawing of different TcN-based platforms suitable for the preparation of target-specific radiopharmaceuticals.

Accordingly, a first chance to include bioactive molecules into a nitrido $\mathrm{Tc}(\mathrm{V})$ complex is offered by the formation of the HS homoleptic bis-substituted dithiocarbamate $\left[{ }^{99 \mathrm{~m}} \mathrm{Tc}\right]\left[\mathrm{TcN}\left(\mathrm{S}_{2} \mathrm{CNR}_{2}\right)_{2}\right]$ complex. In this configuration, the two DTC ligands can be used as bifunctional chelators to link technetium to specific targeting molecules, in a sort of multivalent approach. Dithiocarbamates are, in general, easily prepared by reacting carbon disulfide with a primary or a secondary amine in presence of base; amino groups are present in the chemical structure of several type of bioactive molecules, including pharmacophores and small peptides. Consequently, a variety of substituents can be incorporated in the ligand backbone offering the possibility to generate $\left[{ }^{99 \mathrm{~m}} \mathrm{Tc}\right]\left[\mathrm{TcN}\left(\mathrm{S}_{2} \mathrm{CNR}_{2}\right)_{2}\right]$ complexes for different imaging purposes. Some examples are complexes incorporating antibiotic molecules based on the fluoroquinolone group evaluated as infection imaging agents [118]; a benzamide structure evaluated for diagnosis of malignant melanoma [119]; the nitroimidazole functionality for hypoxia imaging [120]; the glucosamine for tumor imaging as $\left[{ }^{18} \mathrm{~F}\right] \mathrm{FDG}$ mimic [121] and the alendronate group for SPECT imaging of both bone and vascular calcification [122,123].

Besides, $\left[{ }^{99 \mathrm{~m}} \mathrm{Tc}\right]\left[\mathrm{TcN}\left(\mathrm{S}_{2} \mathrm{CNR}_{2}\right)_{2}\right]$ complexes containing the 4-(cyclohexylpiperazine) scaffold were used for the imaging of sigma receptors overexpressed in a variety of cancers [124]; likewise, the 2-methoxyphenylpiperazine moiety was tested for 5-HT1A receptor binding for imaging of brain disorders [125] and the RGDfK motif for non-invasive imaging of $\alpha_{\mathrm{v}} \beta_{3}$ expression in malignant tumors [126,127]. 
The main problem when using this strategy is that the shape and the highly lipophilic character of the constructs negatively affect their distribution profiles which, in general, exhibit very poor pharmacokinetics and low affinities for the molecular target. A further limitation is due to the relatively slow formation kinetics of the DTC-complexes, claiming relatively high ligand amounts (approximately $10^{-4} \mathrm{M}$ ) to afford the final complexes in high RCY, in reasonable time, with the cost of low specific activity of the final complexes.

In spite of the preference of the $[\mathrm{T} c \equiv \mathrm{N}]^{2+}$ core for bidentate over tetradentate ligands, another possibility to include a biologically active molecule into $\left[{ }^{99 \mathrm{~m}} \mathrm{Tc}\right] \mathrm{TcN}-$ based complex is given by the use of the classical bifunctional approach combining a tetradentate chelating system with the biological substrate (Figure 15B). In this connection, bis(thiosemicarbazone) derivatives (BTS), originally introduced as copper chelators in the development of $\mathrm{Cu}$-based agents, were recently investigated as potential bifunctional chelators for $\left[{ }^{99 \mathrm{~m}} \mathrm{Tc}\right][\mathrm{Tc} \equiv \mathrm{N}]^{2+}$ core. Bis(thiosemicarbazone) derivatives efficiently bind the metal, offering the possibility to prepare stable complexes in excellent RCY and good molar activity $(11 \mathrm{GBq} / \mu \mathrm{mol})$ and also providing a new possible pathway in the synthesis of target-specific constructs based on both technetium-99m and copper-64, thus encompassing SPECT and PET imaging and theranostic application [128]. Coordination occurs through the $\mathrm{N}_{2} \mathrm{~S}_{2}$ donor set according to the formulation sketched in Figure 15B; upon coordination, a neutral and lipophilic species is generated. Difficulties in modification of BTS backbone and in its conjugation with the targeting vector are a restriction for the use in RP field.

Based on the biological requirement that only a single bioactive group has to be retained into the structure of the final complex to avoid strong alterations of the properties of the original biomolecule, another possibility to incorporate a molecular vector into a nitrido compound is to prepare heteroleptic compounds in which the metal is bound by a set of different ligands, one of which being conjugated to a targeting molecule selected within a class of proteins, peptides or pharmacophores. Examples of these compounds are reported in Figure 15C-E. In terms of flexibility, the combination of ligands having different denticity (" $2+2$ " or " $3+1$ ") allows at a time of finely tuning the metal coordination site and also the pharmacokinetics of the final complexes.

In this connection, the first (Figure 15C) includes complexes containing the $\left[{ }^{99 \mathrm{~m}} \mathrm{Tc}\right][\mathrm{TcN}(\mathrm{PNP})]^{2+}$ scaffold, which results from the coordination of a PNP ligand to the $\left[{ }^{99 \mathrm{~m}} \mathrm{Tc}\right][\mathrm{TcN}]^{2+}$ core. This basic structural framework possesses quite remarkable stability and high electrophilic character, exhibiting selective reactivity towards the nucleophilic bidentate ligands having a $\sigma$-donor set of coordinating atoms ( $\mathrm{S}$ alternatively combined with $\mathrm{S}, \mathrm{N}$ or $\mathrm{O}$ ) to form solely an asymmetrical nitrido complex in which two different bidentate ligands bind the same technetium center [72,73].

It was found that cysteine efficiently binds the $\left[{ }^{99 \mathrm{~m}} \mathrm{Tc}\right][\mathrm{TcN}(\mathrm{PNP})]^{2+}$ moiety either through the $\left[\mathrm{S}^{\wedge} \mathrm{NH}_{2}\right]^{-}$or $\left[\mathrm{S}^{\wedge} \mathrm{O}\right]^{2-}$ pair yielding very stable heteroleptic compounds in high molar activity (approximately $70 \mathrm{GBq} / \mu \mathrm{mol}$ ) (Table 5) [72]. In this manner, efficient bifunctional ligands can be easily obtained by coupling the selected peptide vector to the $\mathrm{C}$ - or $\mathrm{N}$-terminal group of a cysteine residue, leaving the $\left[\mathrm{S}^{\wedge} \mathrm{NH}_{2}\right]^{-}$or $\left[\mathrm{S}^{\wedge} \mathrm{O}\right]^{2-}$ atom pairs free for coordination. The synthon does not affect the affinity of the vector for the target, allowing the in vitro and in vivo recognition of the receptor [129-140]. 
Table 5. Targeting vectors labeled with $\left[{ }^{99 \mathrm{~m}} \mathrm{Tc}\right][\mathrm{TcN}(\mathrm{PNP})]^{2+}$ building block.

\begin{tabular}{|c|c|c|}
\hline Molecular Vector & Target/Potential Application & Ref. \\
\hline \multicolumn{3}{|l|}{ Small organic molecules (1000 Da) } \\
\hline Biotin & Avidinylate $\mathrm{mAb} /$ pre-targeting tumor & [130] \\
\hline WAY 100635 & $\begin{array}{c}\text { Serotonergic system/imaging of brain } \\
\text { disorders }\end{array}$ & [131] \\
\hline Benzodiazepine & $\begin{array}{l}\text { Benzodiazepine receptors/imaging of brain } \\
\text { disorders }\end{array}$ & [132] \\
\hline Distamycin A & DNA & [136] \\
\hline Folic Acid & $\begin{array}{c}\text { Folate receptors (FRs)/imaging of } \\
\text { receptor-positive tumor cells and } \\
\text { monitoring of tumor response to the } \\
\text { treatment }\end{array}$ & [134] \\
\hline \multicolumn{3}{|l|}{$\begin{array}{c}\text { Peptides } \\
(1000<\mathrm{Da}<2000)\end{array}$} \\
\hline Cys NS-CCK8 & $\begin{array}{c}\text { CCK2 receptor/imaging of MCT, SCLC, } \\
\text { astrocytomas, stromal ovarian tumors, } \\
\text { gastroenteroepatic }\end{array}$ & [135] \\
\hline RGD (Arg-Gly-Asp) based pentapeptide & $\begin{array}{l}\alpha_{\mathrm{v}} \beta_{3} / \alpha_{\mathrm{v}} \beta_{5} \text { integrin/imaging of } \\
\text { angiogenesis, tumor metastasis }\end{array}$ & [136] \\
\hline Annexin V Fragments & Phosphatidylserin/imaging of apoptosis & [137] \\
\hline $\operatorname{BBN}(7-14)$ & $\begin{array}{l}\text { BBN/GR receptors/imaging of colon cancer, } \\
\text { prostate cancer }\end{array}$ & [138] \\
\hline Napamide & $\begin{array}{c}\text { Melanocortin MC1 receptor/Melanoma } \\
\text { imaging }\end{array}$ & [139] \\
\hline RGDEchi & $\begin{array}{c}\alpha_{\mathrm{v}} \beta_{3} \text { integrin/selective angiogenesis, tumor } \\
\text { metastasis imaging }\end{array}$ & [140] \\
\hline
\end{tabular}

The pros and cons of the use of this technology have been summarized in a review by Bolzati et al. [126] and compared with those of the other chemical approaches applied to the conjugation of targeting vectors. The procedure can be adapted to the ${ }^{188}$ Re chemistry $[80,81]$ and the compounds are well-defined from the chemical point of view. Again, the most important feature of this system is the heteroleptic nature of the final compounds, which affords a fine modulation of their physical and chemical properties: chelation systems can be carefully chosen (e.g., $\left[\mathrm{S}^{\wedge} \mathrm{NH}_{2}\right]^{-},\left[\mathrm{S}^{\wedge} \mathrm{O}\right]^{2-}$, and $\left[\mathrm{S}^{\wedge} \mathrm{S}\right]^{2-}$ ) to strike a suitable balance of the physical properties of the final compounds (charge, lipophilicity, etc.) thus making possible the tuning of their overall biological behavior. Usage restrictions may arise by the inability of the radiolabeled compounds to cross the blood-brain-barrier and by the formation of geometrical isomers due to the mutual syn- and anti-orientation of the cysteine pendant group and of the $\mathrm{Tc} \equiv \mathrm{N}$ multiple bond. In respect of this, receptor affinity studies carried out by using the avidin/biotin system as a model showed that when a five-terms spacer is interposed between the Cys chelator and the targeting vector, the two isomeric forms preserve almost the same affinity [130].

The second approach is related to a series of $\left[{ }^{99 \mathrm{~m} / 99} \mathrm{Tc}\right]\left[\mathrm{TcN}\left(\mathrm{R}_{2} \mathrm{PS}\right)\left(\mathrm{S}^{\wedge} \mathrm{S}\right)\right]$ type of complexes (Figure 15D). It was found that the mononegative $\left[\mathrm{S}^{\wedge} \mathrm{S}^{-}\right.$DTC ligands can be considered relatively good bifunctional chelators for the $\left[{ }^{99 \mathrm{~m} / 99} \mathrm{Tc}\right]\left[\mathrm{TcN}\left(\mathrm{R}_{2} \mathrm{PS}\right)\right]^{+}$precursor allowing the production of highly lipophilic neutral compounds $[98,99]$. In this case, usage restrictions come from the complicated labeling procedure, low labeling efficiency $(0.1$ to $0.2 \mathrm{mg} / \mathrm{mL}$ of DTC are necessary to obtain the final complex with RCY $>90 \%$ ) and commercial availability of phosphinothiols (vide supra).

The last approach is provided by the so-called " $3+1$ " method [141]. The schematic drawing of the " $3+1$ " system is depicted in Figure 15E. The coordination sphere of the metal includes a bi-negative $\pi$-donor tridentate ligand, having the $\left[\mathrm{S}^{\wedge} \mathrm{N}^{\wedge}\right]^{2-}$ coordinating set and a neutral monodentate $\pi$-acceptor ligand $\left(\mathrm{PR}_{3}\right.$ phosphine). A very convenient tridentate $\left[\mathrm{S}^{\wedge} \mathrm{N}^{\wedge} \mathrm{S}\right]^{2-}$ chelating system is provided by the combination of two terminal cysteine aminoacids (Cys-Cys). The bioactive molecule can be conjugated to the backbone of one Cys group [142,143]. Another chelating agent used for obtaining a " $3+1$ " system is the HDTCZ. The resulting heteroleptic compounds form when the two ligands 
simultaneously react with the $\left[{ }^{99 \mathrm{~m}} \mathrm{Tc}\right][\mathrm{Tc} \equiv \mathrm{N}]^{2+}{ }_{\text {int }}$ mixture, indicating that the molecular arrangement enjoys a high structural stability $[142,144]$. X-ray diffraction analyses on the corresponding $\operatorname{Re}^{\mathrm{V}} \equiv \mathrm{N}$ analogues display a distorted $t b p$ geometry with the nitrido group and the two sulfur atoms of the SNS ligand on the equatorial plane, while the phosphorus of the monophosphine and the nitrogen of the tridentate ligand take the apical positions. Upon coordination, a syn- and anti-isomeric pair forms, originated by the different orientation of the hydrogen bound to the central nitrogen atom of the tridentate ligand with respect to the $\left[\mathrm{Tc}_{\mathrm{C}} \mathrm{N}\right]^{2+}$ core [141]. The main problem with this system is its low labeling efficiency: relatively high amount of tridentate ligand, ranging from 0.1 to $0.5 \mathrm{mg}$, are needed to obtain the final complex in high RCY. Isomerism might also have a negative effect, in view of the fact that the two isomers might have different biological profiles.

\section{Remarks}

In this review, we provided an overview on the chemical features of the $[\mathrm{Tc} \equiv \mathrm{N}]^{2+}$ core, underlining its uniqueness and providing some important information about its coordination abilities. Data shown here can be exploited to devise efficient strategies in the design and development of new perfusion and target-specific [ $\left.{ }^{99 \mathrm{~m}} \mathrm{Tc}\right] \mathrm{TcN}-\mathrm{RP}$.

Although the chemical requirements of the nitrido core seem to be more demanding with respect to the isoelectronic mono-oxo core as witnessed by the somewhat restricted set of coordinating atoms (mainly S, P, N), its coordination chemistry appears varied, rich, very well established, and can be efficiently manipulated by a careful donating atoms selection, thus offering the possibility to produce geometrically different homoleptic and heteroleptic complexes with remarkable properties in terms of stability and kinetic inertness.

From a structural viewpoint, nitrido $\mathrm{Tc}(\mathrm{V})$ complexes display the metal either in a $s p$ or in $o c$ coordination geometry in which HS arrangements prevail over LS ones. As a result of electronic effects induced by the nitrido group, coordination of a tetradentate ligand to a $[\mathrm{Tc} \equiv \mathrm{N}]^{2+}$ group appears less favored than that obtained by using distinct/different ligands with lower denticity. Besides, the strong trans-labilizing effect operated by the $[\mathrm{Tc} \equiv \mathrm{N}]^{2+}$ core promotes the formation of five-coordinated species rather than six-coordinated ones. In five-coordinated compounds, there is a preference for sulfur-rich $s p$ arrangements characterized by rather long basal Tc-S distances, pointing to a possible partial/total replacement of basal ligands with more efficient chelators. [145] In six-coordinated compounds, the elongation of the $\mathrm{Tc}-\mathrm{X}$ trans distance due to the strong labilizing effect of the $[\mathrm{Tc} \equiv \mathrm{N}]^{2+}$ core produces a deviation from ideal oc arrangements, as also ascertained by the existence of complexes having intermediate coordination numbers $(5,6)$ and characterized by unusually long Tc- $X$ trans distances. This strong labilizing effect makes the TcN-trans position less vulnerable to the action of competing ligands or of other molecules, allowing the complexes to keep their chemical identity unaltered and to preserve a good bioavailability, as proved by the in vitro and in vivo investigation of various HS and LS [ $\left.{ }^{99 \mathrm{~m}} \mathrm{Tc}\right][\mathrm{TcN}]$ agents also including those with tetradenate ligands [146].

Finally, among the $\left[{ }^{99 m} \mathrm{Tc}\right] \mathrm{Tc}(\mathrm{V})$ nitrido compounds proposed so far, the $\left[{ }^{99 \mathrm{~m}} \mathrm{Tc}\right][\mathrm{TcN}(\mathrm{PNP})]^{2+}$ building block represents an interesting structural platform in RP designing, although its full potential remains still to be investigated.

Funding: This research received no external funding.

Conflicts of Interest: The authors declare no conflict of interest. 


\section{Abbreviations}

${ }^{99} \mathrm{Tc}$ radionuclide $\left(\mathrm{E}_{\beta-}=292 \mathrm{keV} ; \mathrm{t} \frac{1}{2}=2.11 \times 10^{5}\right.$ years $)$ for simplicity is denoted as Tc. ${ }^{99 \mathrm{~m}} \mathrm{Tc}$ radionuclide $\left(\mathrm{t} \frac{1}{2}=6.02 \mathrm{~h}, \mathrm{E} \gamma=142 \mathrm{keV}\right.$ ) is represented according to IUPAC nomenclature (e.g., [ $\left.\left.{ }^{99 \mathrm{~m}} \mathrm{Tc}\right][\mathrm{Tc}-]\right)$.

RP

RCY

RCP

99m Tc-MIBI

${ }^{99 \mathrm{~m}} \mathrm{Tc}-\mathrm{Tf}$

14S4

16S4- $(\mathrm{OH})_{2}$

$18 \mathrm{~S} 6$

amec

$\mathrm{AsPh}_{3}$

bipy

bnao

bpa

bpa-bztdm

BTS

$\mathrm{CH}_{3} \mathrm{CN}$

$\mathrm{C}_{9} \mathrm{H}_{6} \mathrm{NS}$

CYS-Oet

DBODC

dedmiy

dmit

dmpe

dppe

DTC

DPTA

eacyd

ecobap

EDTA

en

$\mathrm{Et}_{2}$ DTC

$\mathrm{Et}_{2} \mathrm{NC}(\mathrm{S}) \mathrm{NH}$

etaai

EtOpitc

Hbiguan

HDTCZ

$\mathrm{HEt}_{2} \mathrm{tcb}$

$\mathrm{HNPPh}_{3}$

i-mns

isodtc

Me-dtcz

mnt

morpba

MPO

$\mathrm{NaN}_{3}$

NCS radiopharmaceutical

radiochemical yield

radiochemical purity

99m Tc-sestamibi

99m Tc-tetrofosmin

1,4,8,11-tetrathiacyclotetradecane

1,5,9,13-tetrathiacyclohexadecane-3,11-diol

1,4,7,10,13,16-hexathiacyclooctadecane

$\mathrm{N}$-(2-ammonioethyl)carbamate

triphenylarsine

2,2'-bipyridyl

3,3,10,10-tetramethyl-4,9-diazadodecane-2,11-dione dioximate (1-)

bis-(2-pyridylmethyl)amine

bis-(2-pyridylmethyl)(2-benzylthio-2,2-dimethyl)ethylamine

bis-thiosemicarbazone

acetonitrile

8-quinolinethiolate (1-)

L-cysteine ethyl ester (1-)

bis-(N-ethoxyethyl)-dithiocarbamate (1-)

1,3-diethyl-4,5-dimethylimidazol-2-ylidene

isotrithionedithiolate (2-)

1,2-bis(dimethylphosphino)ethane

1,2-bis(diphenylphosphino)ethane

dithiocarbamate (1-)

1,2-diaminopropane- $N, N, N^{\prime}, N^{\prime}$-tetraacetic acid

$N, N^{\prime}$-ethylenediaminebis(methyl-2-aminocyclopentene-1-dithiocarboxylate (2-)

$N$-(2-ethoxycarbonyl-3-oxobutenyl)-2-aminophenolate (2-)

ethylenediaminetetraacetic acid

ethylenediamine

diethyldithiocarbamate (1-)

$\mathrm{N}, \mathrm{N}$-diethylthiureate (1-)

$N, N^{\prime}$-ethylene-bis(thioacetylacetonylideneiminate) (2-)

O-ethyl(phenylimino)thiocarbonate (1-)

1,1-dimethylbiguanide

dithiocarbazic acid

$\mathrm{N}, \mathrm{N}$-diethylthiocarbamoyl-benzamidinato (1-)

triphenylphosphoraneimine

1,1-dicyanoethene-2,2-diselenolate (2-)

$S$-methyl-3-isopropyylidene-dithiocarbazate (1-)

S-methyl-2-methyldithiocarbazate (1-)

1,2-dicyanoethene-1,2-dithiolate (2-)

$N$-[(morpholino)(thiocarbonyl)]-N'-(2-hydroxyphenyl)benzamidinate (2-)

pyridine-2-thiolate $\mathrm{N}$-oxide (1-)

sodium azide

isothiocyanate (1-) 


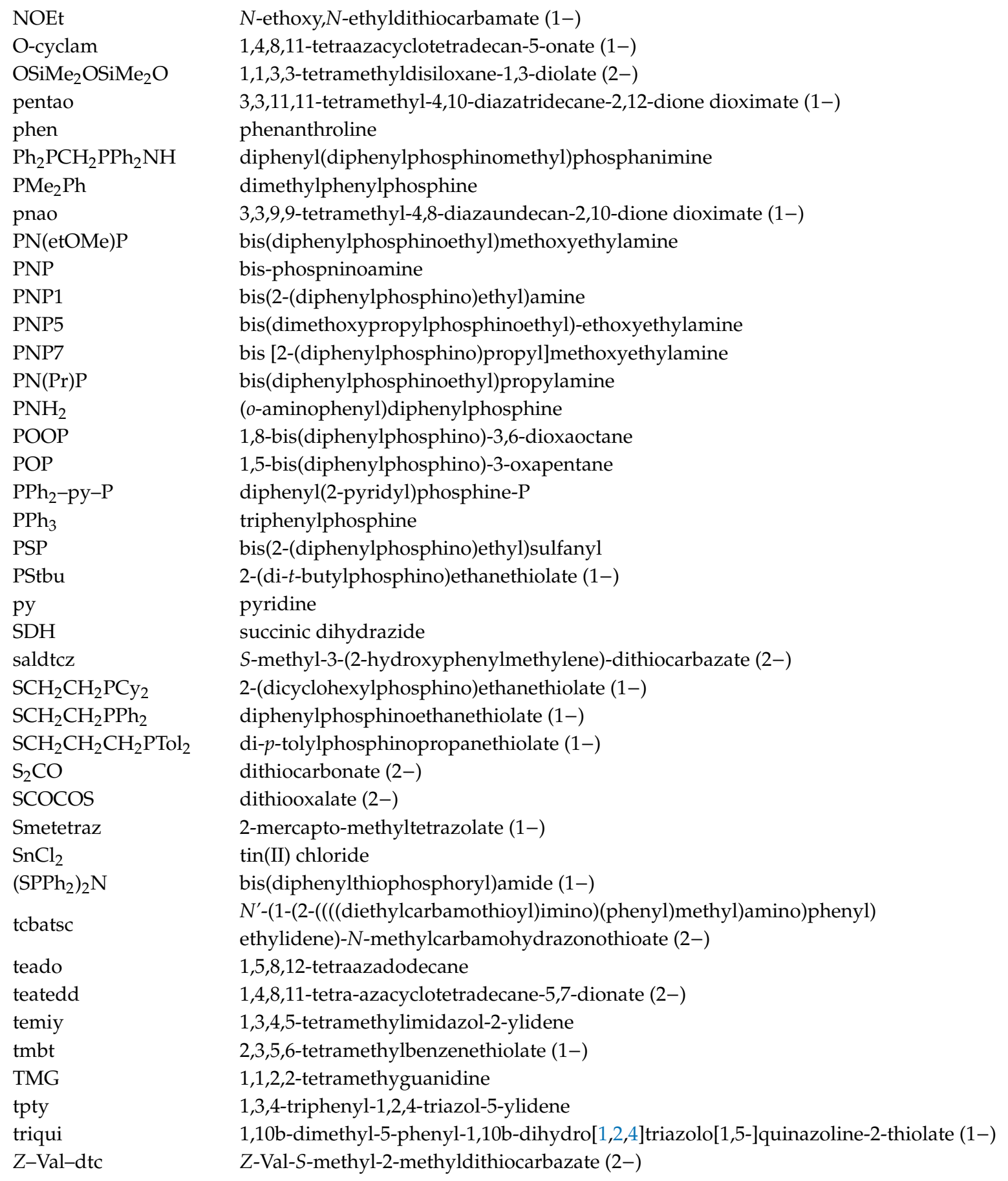

\section{References}

1. Griffith, W.P. Transition metal nitrido complexes. Coord. Chem. Rev. 1972, 8, 369-396. [CrossRef]

2. Baldas, J.; Bonnyman, J.; Pojer, P.M.; Williams, G.A.; Mackay, M.F. Synthesis and structure of bis(diethyldithiocarbamato)nitridotechnetium(V): A technetium-nitrogen triple bond. J. Chem. Soc. Dalton Trans. 1981, 1798-1801. [CrossRef]

3. Boschi, A.; Duatti, A.; Uccelli, L. Development of Technetium-99m and Rhenium-188 Radiopharmaceuticals Containing a Terminal Metal-Nitrido Multiple Bond for Diagnosis and Therapy. Top. Curr. Chem. 2005, 252, 85-115.

4. Baldas, J. The chemistry of technetium nitrido complexes. In Technetium and Rhenium Their Chemistry and Its Applications; Yoshihara, K., Omori, T., Eds.; Topics in Current Chemistry; Springer: Berlin/Heidelberg, Germany, 1996; pp. 37-76. 
5. Bandoli, G.; Dolmella, A.; Porchia, M.; Refosco, F.; Tisato, F. Structural overview of technetium compounds (1993-1999). Coord. Chem. Rev. 2001, 214, 43-90. [CrossRef]

6. Bandoli, G.; Tisato, F.; Dolmella, A.; Agostini, S. Structural overview of technetium compounds (2000-2004). Coord. Chem. Rev. 2006, 250, 561-573. [CrossRef]

7. Tisato, F.; Refosco, F.; Bandoli, G. Structural survey of technetium complexes. Coord. Chem. Rev. 1994, 135-136, 325-397. [CrossRef]

8. Tisato, F.; Bolzati, C.; Porchia, M.; Refosco, F. Contribution of electrospray mass spectrometry for the characterization, design, and development of nitrido technetium and rhenium heterocomplexes as potential radiopharmaceuticals. Mass Spectrom. Rev. 2004, 23, 309-332. [CrossRef]

9. Allen, F.H. The Cambridge Structural Database: A quarter of a million crystal structures and rising. Acta Crystallogr. B 2002, 58, 380-388. [CrossRef]

10. Macrae, C.F.; Bruno, I.J.; Chisholm, J.A.; Edgington, P.R.; McCabe, P.; Pidcock, E.; Rodriguez-Monge, L.; Taylor, R.; van de Streek, J.; Wood, P.A. Mercury CSD 2.0-New features for the visualization and investigation of crystal structures. J. Appl. Crystallogr. 2008, 41, 466-470. [CrossRef]

11. Abram, U.; Dilworth, J.R. Technetium Complexes with 2-Mercapto-methyltetrazolate. Z. Anorg. Allg. Chem. 1999, 625, 609-612. [CrossRef]

12. Braband, H.; Abram, U. Nitridotechnetium(V) Complexes with N-Heterocyclic Carbenes and Unexpected $\left(\mathrm{OSiMe}_{2} \mathrm{OSiMe}_{2} \mathrm{O}\right)^{2-}$ Coligands. Organometallics 2005, 24, 3362-3364. [CrossRef]

13. Rossi, R.; Marchi, A.; Magon, L.; Casellato, U.; Graziani, R. Notes. Synthesis and structure of a new inorganic dianionic bis(dithiocarbonato)nitridotechnetate(V) complex $\mathrm{K}_{2}\left[\mathrm{TcN}\left(\mathrm{S}_{2} \mathrm{CO}\right)_{2}\right] \cdot 2 \mathrm{H}_{2} \mathrm{O}$. J. Chem. Soc. Dalton Trans. 1990, 2923-2925. [CrossRef]

14. Colmanet, S.F.; Mackay, M.F. Crystal structures of $\left(\mathrm{AsPh}_{4}\right)\left[\mathrm{TcO}(\mathrm{SCOCOS})_{2}\right]$ and $\left(\mathrm{AsPh}_{4}\right)_{2}\left[\mathrm{TcN}(\mathrm{SCOCOS})_{2}\right]$. A comparison of the $\mathrm{Tc}^{\mathrm{V}} \mathrm{O}^{3+}$ and $\mathrm{Tc}^{\mathrm{V}} \mathrm{N}^{2+}$ cores in the same coordination environment. Inorg. Chim. Acta 1988, 147, 173-178. [CrossRef]

15. Abram, U.; Münze, R.; Kirmse, R.; Köhler, K.; Dietzsch, W.; Golič, L. Mixed-ligand complexes of technetium IX. Oxidative ligand exchange reactions on tetraphenylarsonium-bis(dithiooxalato)nitridotechnetate(V), $\left(\mathrm{Ph}_{4} \mathrm{As}\right)_{2}\left[\mathrm{TcN}(\mathrm{dto})_{2}\right]$. X-ray crystal structure of a further modification of $\left(\mathrm{Ph}_{4} \mathrm{As}\right)_{2}\left[\mathrm{TcN}(\mathrm{dto})_{2}\right]$. Inorg. Chim. Acta 1990, 169, 49-53. [CrossRef]

16. Williams, G.A.; Baldas, J. Structural Studies of Technetium Complexes. XI. The Crystal Structure of Bis(tetraphenylarsonium) Bis(1,2-dicyanoethenedithiolato)nitridotechnetate(V). Aust. J. Chem. 1989, 42, 875-884. [CrossRef]

17. Dilworth, J.R.; Hübener, R.; Abram, U. Synthesis and Characterization of Bis(tetrabutylammonium) bis(isotrithionedithiolato- $\left.S, S^{\prime}\right)$ nitridotechnetate $(\mathrm{V}),\left(\mathrm{Bu}_{4} \mathrm{~N}\right)_{2}\left[\mathrm{TcN}(\mathrm{dmit})_{2}\right]$. Z. Anorg. Allg. Chem. 1997, 623, 880-882. [CrossRef]

18. Abram, U.; Abram, S.; Stach, J.; Dietzsch, W.; Hiller, W. Technetium Complexes with 1,1-Dicyanoethene-2,2-diselenolate, i-mns ${ }^{2-}$ The Crystal Structure of $\left(\mathrm{Bu}_{4} \mathrm{~N}\right)_{2}\left[\mathrm{TcN}(\mathrm{i}-\mathrm{mns})_{2}\right]$. Z. Anorg. Allg. Chem. 1991, 617, 1185-1187. [CrossRef]

19. Baldas, J.; Boas, J.F.; Colmanet, S.F.; Williams, G.A. Synthesis and structure of di- $\mu$-oxo nitridotechnetium(VI) dimers and a monomeric nitridotechnetium(V) mixed-ligand complex. J. Chem. Soc. Dalton Trans. 1992, 2845-2853. [CrossRef]

20. Abram, U.; Lang, E.S.; Abram, S.; Wegmann, J.; Dilworth, J.R.; Kirmse, R.; Woollins, J.D. Technetium(V) and rhenium(V) nitrido complexes with bis(diphenyl-thiophosphoryl)amide, $\mathrm{N}\left(\mathrm{SPPh}_{2}\right)^{2-}$. J. Chem. Soc. Dalton Trans. 1997, 623-630. [CrossRef]

21. Bolzati, C.; Malagò, E.; Boschi, A.; Cagnolini, A.; Porchia, M.; Bandoli, G. Symmetric bis-substituted and asymmetric mono-substituted nitridotechnetium complexes with heterofunctionalized phosphinothiolate ligands. New J. Chem. 1999, 23, 807-809. [CrossRef]

22. Bolzati, C.; Boschi, A.; Uccelli, L.; Malagò, E.; Bandoli, G.; Tisato, F.; Refosco, F.; Pasqualini, R.; Duatti, A. Synthesis of a Novel Class of Trigonal Bipyramidal Nitrido $\mathrm{Tc}(\mathrm{V})$ Complexes with Phosphino-Thiol Ligands. Crystal Structure of $\left[{ }^{99} \mathrm{~g} \mathrm{Tc}(\mathrm{N})\left(\mathrm{L}^{1}\right)_{2}\right]\left[\mathrm{L}^{1}=2\right.$-(Diphenylphosphino)ethanethiolato] and $\left.{ }^{99} \mathrm{~g} \mathrm{Tc}(\mathrm{N})\left(\mathrm{L}^{5}\right)_{2}\right]\left[\mathrm{L}^{5}=\right.$ 2-(Ditolylphosphino)propanethiolato]. Inorg. Chem. 1999, 38, 4473-4479. [CrossRef] [PubMed]

23. Baldas, J.; Bonnyman, J.; Williams, G.A. Studies of technetium complexes. $9 . \quad$ Use of the tetrachloronitridotechnetate(VI) anion for the preparation of nitrido complexes of technetium. Crystal structure of bis(8-quinolinethiolato)nitridotechnetium(V). Inorg. Chem. 1986, 25, 150-153. [CrossRef] 
24. Duatti, A.; Marchi, A.; Pasqualini, R. Formation of the $\mathrm{Tc}=\mathrm{N}$ multiple bond from the reaction of ammonium pertechnetate with $S$-methyl dithiocarbazate and its application to the preparation of technetium- $99 \mathrm{~m}$ radiopharmaceuticals. J. Chem. Soc. Dalton Trans. 1990, 3729-3733. [CrossRef]

25. Abram, U.; Abram, S.; Dilworth, J.R. Gemischtligandkomplexe des Technetiums. XV. Zur Reaktion von $\left[\mathrm{TCNCl}_{2}\left(\mathrm{Me}_{2} \mathrm{PhP}\right)_{3}\right]$ mit Dialkyldithiocarbamaten und N,N-Dialkylthiocarbamoylbenzamidinen. Z. Anorg. Allg. Chem. 1996, 622, 1257-1262. [CrossRef]

26. Cros, G.; Belhadj Tahar, H.; de Montauzon, D.; Gleizes, A.; Coulais, Y.; Guiraud, R.; Bellande, E.; Pasqualini, R. Synthesis and characterization of neutral oxorhenium $(\mathrm{V})$ and nitridotechnetium $(\mathrm{V})$ complexes with a tetradentate $\mathrm{N}_{2} \mathrm{~S}_{2}$ unsaturated ligand derived from dithiocarboxylic acid. Inorg. Chim. Acta 1994, 227, $25-31$. [CrossRef]

27. Tisato, F.; Mazzi, U.; Bandoli, G.; Cros, G.; Darbieu, M.-H.; Coulais, Y.; Guiraud, R. Neutral oxo and nitrido complexes of technetium $(\mathrm{V})$ and rhenium $(\mathrm{V})$ with an unsaturated tetradentate $\left(\mathrm{N}_{2} \mathrm{~S}_{2}\right)$ ligand. Crystal structure of $\left[N, N^{\prime}\right.$-ethylenebis(thioacetylacetonylideneiminato $\left.](2-) S, S^{\prime}, N, N^{\prime}\right)$ nitridotechnetium(V). J. Chem. Soc. Dalton Trans. 1991, 1301-1307. [CrossRef]

28. Nguyen, H.H.; Castillo Gomez, J.D.; Abram, U. $\operatorname{Re}^{\mathrm{V}} \mathrm{N}$ and $\mathrm{Tc}^{\mathrm{V}} \mathrm{N}$ complexes with a novel tetradentate hybrid benzamidine/thiosemicarbazone ligand. Inorg. Chem. Commun. 2012, 26, 72-76. [CrossRef]

29. Oehlke, E.; Kong, S.; Arciszewski, P.; Wiebalck, S.; Abram, U. Aryl and NHC Compounds of Technetium and Rhenium. J. Am. Chem. Soc. 2012, 134, 9118-9121. [CrossRef]

30. De Vries, N.; Costello, C.E.; Jones, A.G.; Davison, A. Technetium nitrido complexes with amine and thiolate ligands: Structural characterizations of nitridobis(1,1,2,2-tetramethylguanidine)bis(2,3,5,6-tetramethylbenzenethiolato)technetium, a complex with coordinatively bound 1,1,2,2-tetramethylguanidine. Inorg. Chem. 1990, 29, 1348-1352. [CrossRef]

31. Abrams, M.J.; Larsen, S.K.; Shaikh, S.N.; Zubieta, J. Investigations of technetium-organohydrazine coordination chemistry. The crystal and molecular structures of $\left[\mathrm{TcCl}_{2}\left(\mathrm{C}_{8} \mathrm{H}_{5} \mathrm{~N}_{4}\right)\left(\mathrm{PPh}_{3}\right)_{2}\right] \cdot 0.75 \mathrm{C}_{7} \mathrm{H}_{8}$ and $\left[\mathrm{TcNCl}_{2}\left(\mathrm{PPh}_{3}\right)_{2}\right] \cdot 0.25 \mathrm{CH}_{2} \mathrm{Cl}_{2}$. Inorg. Chim. Acta 1991, 185, 7-15. [CrossRef]

32. Gernert, M.B.; Hiller, W.; Dilworth, J.R.; Parrott, S.J. Crystal structure of dichlorobis(triphenylphosphine)nitridotechnetium(V), $\mathrm{TcNCl}_{2}\left(\left(\mathrm{C}_{6} \mathrm{H}_{5}\right)_{3} \mathrm{P}\right)_{2}$. Z. Krist. Cryst. Mater. 2010, 210, 961-962. [CrossRef]

33. Abram, U.; Alberto, R.; Dilworth, J.R.; Zheng, Y.; Ortner, K. Rhenium and technetium complexes with diphenyl(2-pyridyl)phosphine. Polyhedron 1999, 18, 2995-3003. [CrossRef]

34. Baldas, J.; Boas, J.F.; Colmanet, S.F.; Williams, G.A. Electron spin resonance studies of the oxidation of $\left[\mathrm{Tc}^{\mathrm{V}} \mathrm{NCl}_{2}\left(\mathrm{EPh}_{3}\right)_{2}\right](\mathrm{E}=\mathrm{P}$ or $\mathrm{As})$ to $\left[\mathrm{Tc}^{\mathrm{VI}} \mathrm{NCl}_{4}\right]^{-}$by thionyl chloride: Structure of dichloronitridobis(triphenylarsine)-technetium(V). J. Chem. Soc. Dalton Trans. 1991, 2441-2447. [CrossRef]

35. Abram, U.; Hagenbach, A. trans- $\left[\mathrm{TcNCl}_{2}\left(\mathrm{Ph}_{3} \mathrm{PNH}\right)_{2}\right]-$ Synthesis and Structure. Z. Anorg. Allg. Chem. 2002, 628, 1719-1720. [CrossRef]

36. Nguyen, H.H.; Trieu, T.N.; Abram, U. Syntheses and Structures of Nitridorhenium(V) and Nitridotechnetium(V) Complexes with $N, N-\left[(\right.$ Dialkylamino)(thiocarbonyl) $]-N^{\prime}-$ (2-hydroxyphenyl)benzamidines. Z. Anorg. Allg. Chem. 2011, 637, 1330-1333. [CrossRef]

37. Cattabriga, M.; Marchi, A.; Marvelli, L.; Rossi, R.; Vertuani, G.; Pecoraro, R.; Scatturin, A.; Bertolasi, V.; Ferretti, V. Synthesis and structural characterization of technetium and rhenium complexes containing derivatized amino acids. J. Chem. Soc. Dalton Trans. 1998, 1453-1460. [CrossRef]

38. Abram, U.; Abram, S.; Münze, R.; Jäger, E.-G.; Stach, J.; Kirmse, R.; Admiraal, G.; Beurskens, P.T. Mixed-ligand complexes of technetium Part XI. Nitridotechnetium complexes with tri- and tetradentate azomethines. X-ray molecular and crystal structure of [N-(2-ethoxycarbonyl-3-oxo-but-1-en(1)yl)-2-aminophenolato](triphenylphosphine)nitridotechnetium(V), $\mathrm{TcN}\left(\right.$ ecbap) $\left(\mathrm{Ph}_{3} \mathrm{P}\right)$. Inorg. Chim. Acta 1991, 182, 233-238.

39. Ritter, S.; Abram, U.; Dilworth, J.R. Gemischtligandkomplexe des Technetiums. XVI. Darstellung und Struktur von (1,2-Dicyanoethen-1,2-dithiolato)bis(dimethylphenylphosphan)nitridotechnetium(V), [TcN $\left(\mathrm{Me}_{2} \mathrm{PhP}\right)_{2}$ (mnt)]. Z. Anorg. Allg. Chem. 1996, 622, 1975-1978. [CrossRef]

40. Rossi, R.; Marchi, A.; Aggio, S.; Magon, L.; Duatti, A.; Casellato, U.; Graziani, R. The chemistry of heteroallyl derivatives of technetium. Reactivity of $\left[\mathrm{TcNCl}_{2}\left(\mathrm{PPh}_{3}\right)_{2}\right]$ and $\left[\mathrm{Tc}(\mathrm{CO})_{3} \mathrm{Cl}\left(\mathrm{PPh}_{3}\right)\right]$ with thiazetidine ligands, crystal structures of $\left[\mathrm{Tc}(\mathrm{CO})_{2}\left(\mathrm{PPh}_{3}\right)_{2}\{\mathrm{PhNC}(\mathrm{OEt}) \mathrm{S}\}\right]$ and $\left[\mathrm{TcN}(\mathrm{Cl})\left(\mathrm{PPh}_{3}\right)-\{\mathrm{PhNC}(\mathrm{OEt}) \mathrm{S}\}\right]$. J. Chem. Soc. Dalton Trans. 1990, 477-481. [CrossRef] 
41. Bolzati, C.; Cavazza-Ceccato, M.; Agostini, S.; Tisato, F.; Bandoli, G. Technetium and Rhenium in Five-Coordinate Symmetrical and Dissymmetrical Nitrido Complexes with Alkyl Phosphino-thiol Ligands. Synthesis and Structural Characterization. Inorg. Chem. 2008, 47, 11972-11983. [CrossRef]

42. Marchi, A.; Rossi, R.; Marvelli, L.; Bertolasi, V. Nitrido-technetium(V) complexes with amino acids: Preparation and X-ray crystal structure of the L-cysteinate ethyl ester technetium(V) complex. Inorg. Chem. 1993, 32, 4673-4674. [CrossRef]

43. Hecht, M.; Anaya, S.S.; Hagenbach, A.; Abram, U. Rhenium(V) and Technetium(V) Complexes with Phosphoraneimine and Phosphoraneiminato Ligands. Inorg. Chem. 2005, 44, 3172-3180. [CrossRef] [PubMed]

44. Baldas, J.; Boas, J.F.; Colmanet, S.F.; Mackay, M.F. Preparation and structure of bis(tetraphenylarsonium) trans-aquatetracyanonitridotechnetate $(\mathrm{V})$ pentahydrate. ESR studies of the $\left[\mathrm{TcN}(\mathrm{CN})_{4}\left(\mathrm{OH}_{2}\right)\right]^{2-} /\left[\mathrm{TcNCl}_{4}\right]^{-}$ System. Inorg. Chim. Acta 1990, 170, 233-239. [CrossRef]

45. Ikeda, H.; Yoshimura, T.; Ito, A.; Sakuda, E.; Kitamura, N.; Takayama, T.; Sekine, T.; Shinohara, A. Photoluminescence Switching with Changes in the Coordination Number and Coordinating Volatile Organic Compounds in Tetracyanidonitridorhenium(V) and -technetium(V) Complexes. Inorg. Chem. 2012, 51, 12065-12074. [CrossRef]

46. Rochon, F.D.; Melanson, R.; Kong, P.-C. Synthesis and crystal structures of nitrido diphosphinoethane technetium(V) complexes. Polyhedron 1996, 15, 2641-2646. [CrossRef]

47. Marchi, A.; Garuti, P.; Duatti, A.; Magon, L.; Rossi, R.; Ferretti, V.; Bertolasi, V. Synthesis of technetium(V)-nitrido complexes with chelating amines: A novel class of monocationic, octahedral complexes containing the $[\mathrm{Tc} \equiv \mathrm{N}]^{2+}$ core. Crystal structures of $\left[\mathrm{TcN}(\mathrm{en})_{2} \mathrm{Cl}\right]^{+}(\mathrm{en}=$ ethylenediamine $)$ and $[\mathrm{TcN}(\operatorname{tad}) \mathrm{Cl}]^{+}$ (tad = 1,5,8,12-tetraazadodecane). Inorg. Chem. 1990, 29, 2091-2096.

48. Clarke, M.J.; Lu, J. Synthesis and spectra of cis-chloronitridobis(phenanethroline)technetium(1+) chloride hydrate and hexafluorophosphate and considerations of their structural distortions. Inorg. Chem. 1992, 31, 2476-2480. [CrossRef]

49. Archer, C.M.; Dilworth, J.R.; Griffiths, D.V.; McPartlin, M.; Kelly, J.D. Synthesis of technetium-99 nitrido complexes with chelating diphosphine and diimine ligands. J. Chem. Soc. Dalton Trans. 1992, 183-189. [CrossRef]

50. Duatti, A.; Marchi, A.; Bertolasi, V.; Ferretti, V. Isolation and crystal structure of a technetium(V) nitrido complex containing a coordinated transient state of $\mathrm{N}$-(2-aminoethyl)carbamic acid. J. Am. Chem. Soc. 1991, 113, 9680-9682. [CrossRef]

51. Marchi, A.; Marvelli, L.; Cattabriga, M.; Rossi, R.; Neves, M.; Bertolasi, V.; Ferretti, V. Technetium(V) and rhenium $(\mathrm{V})$ complexes of biguanide derivatives. Crystal structures. J. Chem. Soc. Dalton Trans. 1999, 1937-1944. [CrossRef]

52. Marchi, A.; Rossi, R.; Magon, L.; Duatti, A.; Casellato, U.; Graziani, R.; Vidal, M.; Riche, F. Technetium(V) nitrido complexes with tetra-azamacrocycles: Monocationic and neutral octahedral complexes containing the $[\mathrm{TcN}]^{2+}$ core. Crystal structure of $\left[\mathrm{TcN}\left(\mathrm{L}^{1}\right) \mathrm{H}_{2} \mathrm{O}\right] \cdot 2 \mathrm{H}_{2} \mathrm{O}\left(\mathrm{H}_{2} \mathrm{~L}^{1}=1,4,8\right.$,11-tetra-azacyclotetradecane-5,7-dione). J. Chem. Soc. Dalton Trans. 1990, 1935-1940. [CrossRef]

53. Kani, Y.; Takayama, T.; Inomata, S.; Sekine, T.; Kudo, H. Synthesis and Structure of Nitridotechnetium(V) Complex of Tetradentate Amine Oxime [TcN(pnao) $\left.\left(\mathrm{H}_{2} \mathrm{O}\right)\right]^{+}$. Chem. Lett. 1995, 24, 1059-1060. [CrossRef]

54. Kani, Y.; TakayamaTsutomuSekine, T.; Kudo, H. Crystal structures of nitridotechnetium(V) complexes of amine oximes differing in carbon chain lengths. J. Chem. Soc. Dalton Trans. 1999, 209-214. [CrossRef]

55. Pietzsch, H.-J.; Spies, H.; Liebnitz, P.; Reck, G. Technetium complexes with thioether ligands-III. Synthesis and structural characterization of cationic nitridotechnetium $(\mathrm{V})$ complexes with thiacrown ethers. Polyhedron 1993, 12, 2995-3002. [CrossRef]

56. Bertolasi, V.; Ferretti, V.; Gilli, P.; Marchi, A.; Marvelli, L. Structure of trans-aquanitrido(1,4,8,11-tetraazacyclotetradecan-5-onato- $\left.N, N^{\prime}, N^{\prime \prime}, N^{\prime \prime \prime}\right)$ technetium(V) chloride dihydrate. Acta Crystallogr. C 1991, 47, 2535-2539. [CrossRef]

57. Baldas, J.; Bonnyman, J.; Williams, G.A. Structural studies of technetium complexes. Part 4. The crystal structure of trans,trans-acetonitriledi-isothiocyanato(nitrido)bis(triphenylphosphine)technetium(V)-acetonitrile (1/0.5). J. Chem. Soc. Dalton Trans. 1984, 833-837. [CrossRef] 
58. Batsanov, A.S.; Struchkov, Y.T.; Lorenz, B.; Olk, B. Röntgenstrukturanalyse von ${ }^{15}$ N-Nitridodichlorotris(dimethylphenylphenylphosphin)technetium(V). Z. Anorg. Allg. Chem. 1988, 564, 129-134. [CrossRef]

59. Tisato, F.; Refosco, F.; Porchia, M.; Bolzati, C.; Bandoli, G.; Dolmella, A.; Duatti, A.; Boschi, A.; Jung, C.M.; Pietzsch, H.-J.; et al. The Crucial Role of the Diphosphine Heteroatom $X$ in the Stereochemistry and Stabilization of the Substitution-Inert $[\mathrm{M}(\mathrm{N})(\mathrm{PXP})]^{2+}$ Metal Fragments $(\mathrm{M}=\mathrm{Tc}$, Re; PXP = Diphosphine Ligand). Inorg. Chem. 2004, 43, 8617-8625. [CrossRef]

60. Yoshimura, T.; Nagata, K.; Shiroyama, T.; Kino, Y.; Takayama, T.; Sekine, T.; Shinohara, A. A luminescent dicyanidonitridotechnetium $(\mathrm{V})$ core with tridentate ligand coordination sites. Dalton Trans. 2018, 47, 16027-16030. [CrossRef]

61. Dilworth, J.R.; Griffiths, D.V.; Hughes, J.M.; Morton, S.; Hiller, W.; Archer, C.M.; Kelly, J.D.; Walton, G. Technetium complexes of capped tetradentate ligands I. The synthesis and crystal and molecular structure of $\left[\mathrm{TcBr}_{2} \mathrm{~N}\left\{\left(\mathrm{pyCH}_{2}\right)_{2} \mathrm{NCH}_{2} \mathrm{CMe}_{2} \mathrm{SCH}_{2} \mathrm{Ph}\right\}\right]$ (py = 2-pyridyl) and its behaviour in solution. Inorg. Chim. Acta 1992, 192, 59-63. [CrossRef]

62. Ikeda, H.; Ito, A.; Sakuda, E.; Kitamura, N.; Takayama, T.; Sekine, T.; Shinohara, A.; Yoshimura, T. Excited-State Characteristics of Tetracyanidonitridorhenium(V) and -technetium(V) Complexes with N-Heteroaromatic Ligands. Inorg. Chem. 2013, 52, 6319-6327. [CrossRef] [PubMed]

63. Marchi, A.; Marvelli, L.; Rossi, R.; Magon, L.; Uccelli, L.; Bertolasi, V.; Ferretti, V.; Zanobini, F. Nitrido-technetium and -rhenium complexes with chelating phosphines: Synthesis, reactivity and crystal structures. J. Chem. Soc. Dalton Trans. 1993, 1281-1286. [CrossRef]

64. Bolzati, C.; Boschi, A.; Duatti, A.; Prakash, S.; Uccelli, L.; Refosco, F.; Tisato, F.; Bandoli, G. Geometrically Controlled Selective Formation of Nitrido Technetium(V) Asymmetrical Heterocomplexes with Bidentate Ligands. J. Am. Chem. Soc. 2000, 122, 4510-4511. [CrossRef]

65. Bolzati, C.; Boschi, A.; Uccelli, L.; Tisato, F.; Refosco, F.; Cagnolini, A.; Duatti, A.; Prakash, S.; Bandoli, G.; Vittadini, A. Chemistry of the Strong Electrophilic Metal Fragment $\left[{ }^{99} \mathrm{Tc}(\mathrm{N})(\mathrm{PXP})\right]^{2+}(\mathrm{PXP}=$ Diphosphine Ligand). A Novel Tool for the Selective Labeling of Small Molecules. J. Am. Chem. Soc. 2002, 124, 11468-11479. [CrossRef]

66. Figgis, B.N.; Reynolds, P.A.; Larsen, F.K.; Williams, G.A.; Delfs, C.D. Low-Temperature Structure and Magnetic Properties of Tetraphenylarsonium Tetrachloronitridotechnetate(VI). Aust. J. Chem. 1996, 49, 633-637. [CrossRef]

67. Abram, U.; Hübener, R.; Wollert, R.; Kirmse, R.; Hiller, W. Synthesis, characterization and reactions of $\left[\mathrm{Tc}(\mathrm{NS}) \mathrm{X}_{4}\right]^{-}$complexes $(\mathrm{X}=\mathrm{Cl}, \mathrm{Br}, \mathrm{NCS})$. Inorg. Chim. Acta 1993, 206, 9-14. [CrossRef]

68. Baldas, J.; Colmanet, S.F.; Williams, G.A. Preparation of the technetium(VI) aquanitrido complexes $\left(\mathrm{NEt}_{4}\right)\left[\mathrm{TcNX}_{4}\left(\mathrm{OH}_{2}\right)\right](\mathrm{X}=\mathrm{Cl}$ or Br$)$. Crystal structures of $\left(\mathrm{NEt}_{4}\right)\left[\mathrm{TcNBr}_{4}\left(\mathrm{OH}_{2}\right)\right]$ and $\mathrm{Cs}_{2}\left[\mathrm{TcNCl}_{5}\right]$. Inorg. Chim. Acta 1991, 179, 189-194. [CrossRef]

69. Lorenz, B.; Kränke, P.; Schmidt, K.; Krimse, R.; Hübener, R.; Abram, U. Synthese, EPR und Röntgenkristallstrukturanalyse von mer-Trichloro(2,2'-bipyridin)nitridotechnetium(VI), einem neuen Nitridokomplex des Technetium(VI). Z. Anorg. Allg. Chem. 1994, 620, 921-925. [CrossRef]

70. Addison, A.W.; Rao, T.N.; Reedijk, J.; van Rijn, J.; Verschoor, G.C. Synthesis, structure, and spectroscopic properties of copper(II) compounds containing nitrogen-sulphur donor ligands; the crystal and molecular structure of aqua[1,7-bis(N-methylbenzimidazol-2'-yl)-2,6-dithiaheptane]copper(II) perchlorate. J. Chem. Soc. Dalton Trans. 1984, 1349-1356. [CrossRef]

71. Konno, T.; Tokuda, K.; Sakurai, J.; Okamoto, K. Five-Coordinate Geometry of Cadmium(II) with Octahedral Bidentate-S,S Complex-Ligand cis(S)-[Co(aet)2(en) $]^{+}$(aet = 2-aminoethanethiolate): Synthesis, Crystal Structures and Interconversion of S-Bridged $\mathrm{Co}^{\mathrm{III}} \mathrm{Cd}^{\mathrm{II}}$ Polynuclear Complexes. Bull. Chem. Soc. Jpn. 2000, 73, 2767-2773. [CrossRef]

72. Boschi, A.; Bolzati, C.; Benini, E.; Malagò, E.; Uccelli, L.; Duatti, A.; Piffanelli, A.; Refosco, F.; Tisato, F. A Novel Approach to the High-Specific-Activity Labeling of Small Peptides with the Technetium-99m Fragment $\left[{ }^{99 m} \mathrm{Tc}(\mathrm{N})(\mathrm{PXP})\right]^{2+}(\mathrm{PXP}=$ Diphosphine Ligand). Bioconjug. Chem. 2001, 12, 1035-1042. [CrossRef] [PubMed]

73. Bolzati, C.; Benini, E.; Cazzola, E.; Jung, C.; Tisato, F.; Refosco, F.; Pietzsch, H.-J.; Spies, H.; Uccelli, L.; Duatti, A. Synthesis, Characterization, and Biological Evaluation of Neutral Nitrido Technetium(V) Mixed Ligand Complexes Containing Dithiolates and Aminodiphosphines. A Novel System for Linking Technetium to Biomolecules. Bioconjug. Chem. 2004, 15, 628-637. [CrossRef] [PubMed] 
74. Baldas, J.; Bonnyman, J. Substitution reactions of ${ }^{99} \mathrm{TcNCl}_{4}{ }^{-}-\mathrm{A}$ route to a new class of 99m Tc-radiopharmaceuticals. Int. J. Appl. Radiat. Isot. 1985, 36, 133-139. [CrossRef]

75. Baldas, J.; Bonnyman, J. ${ }^{99 \mathrm{~m}} \mathrm{Tc}$-nitrido radiopharmaceuticals based on nitrogen heterocyclic ligands containing a thiol group. Int. J. Rad. Appl. Instrum. B 1988, 15, 451-457. [CrossRef]

76. Marchi, A.; Duatti, A.; Rossi, R.; Magon, L.; Pasqualini, R.; Bertolasi, V.; Ferretti, V.; Gilli, G. Technetium(V)-nitrido complexes of dithiocarbazic acid derivatives. Reactivity of $[\mathrm{Tc} \equiv \mathrm{N}]^{2+}$ core towards Schiff bases derived from S-methyl dithiocarbazate. Crystal structures of [S-methyl 3-(2-hydroxyphenylmethylene)dithiocarbazato]nitrido(triphenylphosphine)technetium(V) and bis(S-methyl 3-isopropylidenedithiocarbazato)nitridotechnetium(V). J. Chem. Soc. Dalton Trans. 1988, 1743-1749. [CrossRef]

77. Pasqualini, R.; Comazzi, V.; Bellande, E.; Duatti, A.; Marchi, A. A new efficient method for the preparation of ${ }^{99 m}$ Tc-radiopharmaceuticals containing the $\mathrm{Tc} \equiv \mathrm{N}$ multiple bond. Int. J. Rad. Appl. Instrum. 1992, 43, 1329-1333. [CrossRef]

78. Pasqualini, R.; Duatti, A. Synthesis and characterization of the new neutral myocardial imaging agent $\left[{ }^{99 \mathrm{~m}} \mathrm{TcN}(\text { noet })_{2}\right]$ (noet $=\mathrm{N}$-ethyl-N-ethoxydithiocarbamato). J. Chem. Soc. Chem. Commun. 1992, 1354-1355. [CrossRef]

79. Bellande, E.; Charmoille, M.; Pasqualini, R. Synthesis of 186Re Nitrido Complexes; Nicolini, M., Mazzi, U., Eds.; SGE Editoriali-Padova Italy: Padova, Italy, 1999; Volume 5, pp. 149-152.

80. Carta, D.; Jentschel, C.; Thieme, S.; Salvarese, N.; Morellato, N.; Refosco, F.; Ruzza, P.; Bergmann, R.; Pietzsch, H.-J.; Bolzati, C. Assessment of the best $\mathrm{N}^{3-}$ donors in preparation of $[\mathrm{M}(\mathrm{N})(\mathrm{PNP})]$-based $\left(\mathrm{M}={ }^{99 \mathrm{~m}} \mathrm{Tc}-;{ }^{188} \mathrm{Re}\right)$ target-specific radiopharmaceuticals: Comparison among succinic dihydrazide (SDH), $N$-methyl-S-methyl dithiocarbazate (HDTCZ) and PEGylated N-methyl-S-methyl dithiocarbazate ( $\mathrm{HO}_{2} \mathrm{C}-\mathrm{PEG}_{600}$-DTCZ). Nucl. Med. Biol. 2014, 41, 570-581.

81. Thieme, S.; Agostini, S.; Bergmann, R.; Pietzsch, J.; Pietzsch, H.-J.; Carta, D.; Salvarese, N.; Refosco, F.; Bolzati, C. Synthesis, characterization and biological evaluation of $\left[{ }^{188} \operatorname{Re}(\mathrm{N})(\mathrm{cys} \sim)(\mathrm{PNP})\right]^{+/ 0}$ mixed-ligand complexes as prototypes for the development of ${ }^{188} \operatorname{Re}(\mathrm{N})$-based target-specific radiopharmaceuticals. Nucl. Med. Biol. 2011, 38, 399-415. [CrossRef]

82. Boschi, A.; Bolzati, C.; Uccelli, L.; Duatti, A. High-yield synthesis of the terminal $188 \mathrm{Re} \equiv \mathrm{N}$ multiple bond from generator-produced $\left[{ }^{188} \mathrm{ReO}_{4}\right]^{-}$. Nucl. Med. Biol. 2003, 30, 381-387. [CrossRef]

83. Dahlberg, S.T. Assessment of myocardial perfusion with Tc-99m: Image is everything. J. Nucl. Cardiol. 2009, 16, 493-496. [CrossRef] [PubMed]

84. Beller, G.A. Recent advances and future trends in multimodality cardiac imaging. Heart Lung Circ. 2010, 19, 193-209. [CrossRef] [PubMed]

85. Pasqualini, R.; Duatti, A.; Bellande, E.; Comazzi, V.; Brucato, V.; Hoffschir, D.; Fagret, D.; Comet, M. Bis(Dithiocarbamato) Nitrido Technetium-99m Radiopharmaceuticals: A Class of Neutral Myocardial Imaging Agents. J. Nucl. Med. 1994, 35, 334-341. [PubMed]

86. Vanzetto, G.; Fagret, D.; Pasqualini, R.; Mathieu, J.P.; Chossat, F.; Machecourt, J. Biodistribution, Dosimetry, and Safety of Myocardial Perfusion Imaging Agent ${ }^{99 \mathrm{~m}}$ TcN-NOET in Healthy Volunteers. J. Nucl. Med. 2000, 41, 141-148. [PubMed]

87. Ghezzi, C.; Fagret, D.; Arvieux, C.C.; Mathieu, J.-P.; Bontron, R.; Pasqualini, R.; de Leiris, J.; Comet, M. Myocardial Kinetics of TcN-NOET: A Neutral Lipophilic Complex Tracer of Regional Myocardial Blood Flow. J. Nucl. Med. 1995, 36, 1069-1077. [PubMed]

88. Holly, T.A.; Leppo, J.A.; Gilmore, M.P.; Reinhardt, C.P.; Dahlberg, S.T. The effect of ischemic injury on the cardiac transport of Tc-99m N-NOET in the isolated rabbit heart. J. Nucl. Cardiol. 1999, 6, 633-640. [CrossRef]

89. Takehana, K.; Beller, G.A.; Ruiz, M.; Petruzella, F.D.; Watson, D.D.; Glover, D.K. Assessment of Residual Coronary Stenoses Using ${ }^{99 \mathrm{~m}} \mathrm{Tc}-\mathrm{N}-\mathrm{NOET}$ Vasodilator Stress Imaging to Evaluate Coronary Flow Reserve Early After Coronary Reperfusion in a Canine Model of Subendocardial Infarction. J. Nucl. Med. 2001, 42, 1388-1394.

90. Calnon, D.A.; Ruiz, M.; Vanzetto, G.; Watson, D.D.; Beller, G.A.; Glover, D.K. Myocardial Uptake of ${ }^{99 \mathrm{~m}} \mathrm{Tc}-\mathrm{N}-\mathrm{NOET}$ and ${ }^{201} \mathrm{Tl}$ During Dobutamine Infusion. Circulation 1999, 100, 1653-1659. [CrossRef]

91. Vanzetto, G.; Calnon, D.A.; Ruiz, M.; Watson, D.D.; Pasqualini, R.; Beller, G.A.; Glover, D.K. Myocardial Uptake and Redistribution of ${ }^{99 m}$ Tc-N-NOET in Dogs with either Sustained Coronary Low Flow or Transient Coronary Occlusion. Circulation 1997, 96, 2325-2331. [CrossRef] 
92. Fagret, D.; Marie, P.-Y.; Brunotte, F.; Giganti, M.; Guludec, D.L.; Bertrand, A.; Wolf, J.-E.; Piffanelli, A.; Chossat, F.; Bekhechi, D.; et al. Myocardial Perfusion Imaging with Technetium-99m-Tc NOET: Comparison with Thallium-201 and Coronary Angiography. J. Nucl. Med. 1995, 36, 936-943.

93. Uccelli, L.; Giganti, M.; Duatti, A.; Bolzati, C.; Pasqualini, R.; Cittanti, C.; Colamussi, P.; Piffanelli, A. Subcellular Distribution of Technetium-99m-N-NOEt in Rat Myocardium. J. Nucl. Med. 1995, 36, 2075-2079. [PubMed]

94. Riou, L.; Ghezzi, C.; Pasqualini, R.; Fagret, D. Influence of calcium channel inhibitors on the myocardial uptake and retention of technetium-99m N-NOET, a new myocardial perfusion imaging agent: A study on isolated perfused rat hearts. J. Nucl. Cardiol. 2000, 7, 365-372. [CrossRef] [PubMed]

95. Fagret, D.; Ghezzi, C.; Vanzetto, G. ${ }^{99 \mathrm{~m}}$ Tc-N-NOET Imaging for Myocardial Perfusion: Can It Offer More Than We Already Have? J. Nucl. Med. 2001, 42, 1395-1396. [PubMed]

96. Bottlaender, M.; Bourguignon, M.; Maziere, M. Technetium-99m nitrido dithiocarbamate complex with lateral ester groups: A potential agent for cerebral perfusion. Direct labeling and kinetic results in baboons. J. Nucl. Med. 1994, 35, 154-164.

97. Bolzati, C.; Uccelli, L.; Boschi, A.; Malagò, E.; Duatti, A.; Tisato, F.; Refosco, F.; Pasqualini, R.; Piffanelli, A. Synthesis of a novel class of nitrido Tc-99m radiopharmaceuticals with phosphino-thiol ligands showing transient heart uptake. Nucl. Med. Biol. 2000, 27, 369-374. [CrossRef]

98. Bolzati, C.; Benini, E.; Cavazza-Ceccato, M.; Cazzola, E.; Malagò, E.; Agostini, S.; Tisato, F.; Refosco, F.; Bandoli, G. From Symmetrical to Asymmetrical Nitrido Phosphino-thiol Complexes: A New Class of Neutral Mixed-Ligand ${ }^{99 m}$ Tc Compounds as Potential Brain Imaging Agents. Bioconjug. Chem. 2006, 17, 419-428. [CrossRef]

99. Bolzati, C.; Salvarese, N.; Carta, D.; Refosco, F.; Dolmella, A.; Pietzsch, H.J.; Bergmann, R.; Bandoli, G. Synthesis and biological evaluation of new [Tc(N)(PS)]-based mixed-ligand compounds useful in the design of target-specific radiopharmaceuticals: The 2-methoxyphenylpiperazine dithiocarbamate derivatives as an example. J. Biol. Inorg. Chem. 2011, 16, 137-155. [CrossRef]

100. Boschi, A.; Bolzati, C.; Uccelli, L.; Duatti, A.; Benini, E.; Refosco, F.; Tisato, F.; Piffanelli, A. A class of asymmetrical nitrido Tc-99m heterocomplexes as heart imaging agents with improved biological properties. Nucl. Med. Commun. 2002, 23, 689-693. [CrossRef]

101. Boschi, A.; Uccelli, L.; Bolzati, C.; Duatti, A.; Sabba, N.; Moretti, E.; Domenico, G.D.; Zavattini, G.; Refosco, F.; Giganti, M. Synthesis and Biologic Evaluation of Monocationic Asymmetric ${ }^{99 \mathrm{~m}}$ Tc-Nitride Heterocomplexes Showing High Heart Uptake and Improved Imaging Properties. J. Nucl. Med. 2003, 44, 806-814.

102. Kim, Y.-S.; He, Z.; Hsieh, W.-Y.; Liu, S. Impact of Bidentate Chelators on Lipophilicity, Stability, and Biodistribution Characteristics of Cationic ${ }^{99 m}$ Tc-Nitrido Complexes. Bioconjug. Chem. 2007, 18, 929-936. [CrossRef]

103. Kim, Y.-S.; Shi, J.; Zhai, S.; Hou, G.; Liu, S. Mechanism for myocardial localization and rapid liver clearance of Tc-99m-N-MPO: A new perfusion radiotracer for heart imaging. J. Nucl. Cardiol. 2009, 16, 571-579. [CrossRef] [PubMed]

104. Bolzati, C.; Cavazza-Ceccato, M.; Agostini, S.; Refosco, F.; Yamamichi, Y.; Tokunaga, S.; Carta, D.; Salvarese, N.; Bernardini, D.; Bandoli, G. Biological in Vitro and in Vivo Studies of a Series of New Asymmetrical Cationic $\left[{ }^{99 m} \mathrm{Tc}(\mathrm{N})(\mathrm{DTC}-\mathrm{Ln})(\mathrm{PNP})\right]^{+}$Complex (DTC-Ln = Alicyclic Dithiocarbamate and PNP = Diphosphinoamine). Bioconjug. Chem. 2010, 21, 928-939. [CrossRef] [PubMed]

105. Salvarese, N.; Carta, D.; Marzano, C.; Gerardi, G.; Melendez-Alafort, L.; Bolzati, C. $\left[{ }^{99 m} \mathrm{Tc}\right][\mathrm{Tc}(\mathrm{N})(\mathrm{DASD})(\mathrm{PNPn})]^{+}$(DASD = 1,4-Dioxa-8-azaspiro[4,5]decandithiocarbamate, PNPn = Bisphosphinoamine) for Myocardial Imaging: Synthesis, Pharmacological and Pharmacokinetic Studies. J. Med. Chem. 2018, 61, 11114-11126. [CrossRef] [PubMed]

106. Bolzati, C.; Refosco, F.; Cagnolini, A.; Tisato, F.; Boschi, A.; Duatti, A.; Uccelli, L.; Dolmella, A.; Marotta, E.; Tubaro, M. Synthesis, Solution-State and Solid-State Structural Characterization of Monocationic Nitrido Heterocomplexes $[\mathrm{M}(\mathrm{N})(\mathrm{DTC})(\mathrm{PNP})]^{+}\left(\mathrm{M}={ }^{99} \mathrm{Tc}, \mathrm{Re} ; \mathrm{DTC}=\right.$ Dithiocarbamate; PNP = Heterodiphosphane). Eur. J. Inorg. Chem. 2004, 2004, 1902-1913. [CrossRef]

107. Hatada, K.; Ruiz, M.; Riou, L.M.; Lima, R.L.; Goode, A.R.; Watson, D.D.; Beller, G.A.; Glover, D.K. Organ biodistribution and myocardial uptake, washout, and redistributionkinetics of Tc-99m N-DBODC5 when injected during vasodilator stress in canine models of coronary stenoses. J. Nucl. Cardiol. 2006, 6, 779-790. [CrossRef] 
108. Glover, D.K.; Ruiz, M.; Yang, J.Y.; Smith, W.H.; Watson, D.D.; Beller, G.A. Myocardial ${ }^{99 m}$ Tc-tetrofosmin uptake during adenosine-induced vasodilatation with either a critical or mild coronary stenosis: Comparison with ${ }^{201} \mathrm{Tl}$ and regional myocardial blood flow. Circulation 1997, 96, 2332-2338. [CrossRef]

109. Glover, D.K.; Ruiz, M.; Takehana, K.; Petruzella, F.D.; Riou, L.M.; Rieger, J.M.; Macdonald, T.L.; Watson, D.D.; Linden, J.; Beller, G.A. Pharmacological stress myocardial perfusion imaging with the potent and selective A(2A) adenosine receptor agonists ATL193 and ATL146e administered by either intravenous infusion or bolus injection. Circulation 2001, 104, 1181-1187. [CrossRef]

110. Glover, D.K.; Ruiz, M.; Edwards, N.C.; Cunningham, M.; Simanis, J.P.; Smith, W.H.; Watson, D.D.; Beller, G.A. Comparison between ${ }^{201} \mathrm{Tl}$ and ${ }^{99 \mathrm{~m}}$ Tcsestamibi uptake during adenosine-induced vasodilatation as a function of coronary stenosis severity. Circulation 1995, 91, 813-820. [CrossRef]

111. Rumsey, W.L.; Rosenspire, K.C.; Nunn, A.D. Myocardial extraction of teboroxime: Effects of teboroxime interaction with blood. J. Nucl. Med. 1992, 33, 94-101.

112. Vanzetto, G.; Glover, D.K.; Ruiz, M.; Calnon, D.A.; Pasqualini, R.; Watson, D.D.; Beller, G.A. ${ }^{99 m}$ Tc-NNOET myocardial uptake reflects myocardial blood flow and not viability in dogs with reperfused acute myocardial infarction. Circulation. 2000, 101, 2424-2430. [CrossRef]

113. Bolzati, C.; Cavazza-Ceccato, M.; Agostini, S.; Tokunaga, S.; Casara, D.; Bandoli, G. Subcellular Distribution and Metabolism Studies of the Potential Myocardial Imaging Agent $\left[{ }^{99 \mathrm{~m}} \mathrm{Tc}(\mathrm{N})(\mathrm{DBODC})(\mathrm{PNP} 5)\right]^{+}$. J. Nucl. Med. 2008, 49, 1336-1344. [CrossRef] [PubMed]

114. Bolzati, C.; Carta, D.; Gandin, V.; Marzano, C.; Morellato, N.; Salvarese, N.; Cantore, M.; Colabufo, N.A. ${ }^{99 m} \mathrm{Tc}(\mathrm{N})-\mathrm{DBODC}(5)$, a potential radiolabeled probe for SPECT of multidrug resistance: In vitro study. $J$. Biol. Inorg. Chem. 2013, 18, 523-538. [CrossRef] [PubMed]

115. Cittanti, C.; Uccelli, L.; Pasquali, M.; Boschi, A.; Flammia, C.; Bagatin, E.; Casali, M.; Stabin, M.G.; Feggi, L.; Giganti, M.; et al. Whole-Body Biodistribution and Radiation Dosimetry of the New Cardiac Tracer 99m Tc-N-DBODC. J. Nucl. Med. 2008, 49, 1299-1304. [CrossRef] [PubMed]

116. Ma, H.; Li, S.; Wu, Z.; Liu, J.; Liu, H.; Guo, X. Comparison of ${ }^{99 \mathrm{~m}} \mathrm{Tc}-\mathrm{N}-\mathrm{DBODC} 5$ and ${ }^{99 \mathrm{~m}} \mathrm{Tc}-\mathrm{MIBI}$ of Myocardial Perfusion Imaging for Diagnosis of Coronary Artery Disease. BioMed Res. Int. 2013, 2013, 145427. [CrossRef]

117. Riou, L.M.; Broisat, A. Novel SPECT perfusion imaging agents with improved myocardial or liver kinetics: Experimental studies and the need for clinical evaluation. J. Nucl. Cardiol. 2010, 17, 771-774. [CrossRef]

118. Naqvi, S.A.R.; Roohi, S.; Iqbal, A.; Sherazi, T.A.; Zahoor, A.F.; Imran, M. Ciprofloxacin: From infection therapy to molecular imaging. Mol. Biol. Rep. 2018, 45, 1457-1468. [CrossRef]

119. Auzeloux, P.; Papon, J.; Masnada, T.; Borel, M.; Moreau, M.-F.; Veyre, A.; Pasqualini, R.; Madelmont, J.-C. Synthesis and biodistribution of technetium-99m-labelled $N$-(diethylaminoethyl)benzamide via a bis(dithiocarbamate) nitridotechnetium(V) complex. J. Label. Compd. Radiopharm. 1999, 42, 325-335. [CrossRef]

120. Giglio, J.; Fernández, S.; Rey, A.; Cerecetto, H. Synthesis and biological characterization of novel dithiocarbamate containing 5-nitroimidazole ${ }^{99 \mathrm{~m}} \mathrm{Tc}$-complexes as potential agents for targeting hypoxia. Bioorg. Med. Chem. Lett. 2011, 21, 394-397. [CrossRef]

121. Zhang, J.; Ren, J.; Lin, X.; Wang, X. Synthesis and biological evaluation of a novel ${ }^{99 \mathrm{~m}} \mathrm{Tc}$ nitrido radiopharmaceutical with deoxyglucose dithiocarbamate, showing tumor uptake. Bioorg. Med. Chem. Lett. 2009, 19, 2752-2754. [CrossRef]

122. Song, X.; Wang, Y.; Zhang, J.; Jin, Z.; Zhang, W.; Zhang, Y. Synthesis and evaluation of a novel ${ }^{99 \mathrm{~m}}$ Tc nitrido radiopharmaceutical with alendronate dithiocarbamate as a potential bone-imaging agent. Chem. Biol. Drug Des. 2018, 91, 545-551. [CrossRef]

123. Bordoloi, J.K.; Berry, D.; Khan, I.U.; Sunassee, K.; de Rosales, R.T.M.; Shanahan, C.; Blower, P.J. Technetium-99m and rhenium-188 complexes with one and two pendant bisphosphonate groups for imaging arterial calcification. Dalton Trans. 2015, 44, 4963-4975. [CrossRef] [PubMed]

124. Lu, J.; Kong, D.; Jia, H.; Deuther-Conrad, W.; Brust, P.; Wang, X. Preparation and biological evaluation of ${ }^{99 m} \mathrm{TcN}-4$-(cyclohexylpiperazin-1-yl)-dithioformate as a potential sigma receptor imaging agent. J. Label. Compd. Radiopharm. 2007, 50, 1200-1205. [CrossRef]

125. Yang, W.; Lin, Y.; Zhang, X.; Zhang, J.; Wang, X. Synthesis of several MPP derivatives for ${ }^{99 \mathrm{~m}}$ Tc-labeling and evaluated as potential 5-HT1A receptor imaging agents. Sci. China Chem. 2011, 54, 1148-1154. [CrossRef] 
126. Mittal, S.; Bhadwal, M.; Chakraborty, S.; Sarma, H.D.; Banerjee, S.; Pillai, M.R.A. A novel concept of radiosynthesis of a ${ }^{99 \mathrm{~m}} \mathrm{Tc}-$ labeled dimeric RGD peptide as a potential radiotracer for tumor imaging. Bioorg. Med. Chem. Lett. 2013, 23, 1808-1812. [CrossRef]

127. Caporale, A.; Bolzati, C.; Incisivo, G.M.; Salvarese, N.; Grieco, P.; Ruvo, M. Improved synthesis on solid phase of dithiocarbamic cRGD-derivative and ${ }^{99} \mathrm{~m}$ Tc-radiolabeling. J. Pept. Sci. 2019, 25, e3140. [CrossRef]

128. Salvarese, N.; Spolaore, B.; Marangoni, S.; Pasin, A.; Galenda, A.; Tamburini, S.; Cicoria, G.; Refosco, F.; Bolzati, C. Transglutaminase-mediated conjugation and nitride-technetium-99m labeling of a bis(thiosemicarbazone) bifunctional chelator. J. Inorg. Biochem. 2018, 183, 18-31. [CrossRef]

129. Bolzati, C.; Carta, D.; Salvarese, N.; Refosco, F. Chelating systems for ${ }^{99 \mathrm{~m}} \mathrm{Tc} /{ }^{188}$ Re in the development of radiolabeled peptide pharmaceuticals. Anti-Cancer Agents Med. Chem. 2012, 12, 428-461. [CrossRef]

130. Bolzati, C.; Caporale, A.; Agostini, S.; Carta, D.; Cavazza-Ceccato, M.; Refosco, F.; Tisato, F.; Schievano, E.; Bandoli, G. Avidin-biotin system: A small library of cysteine biotinylated derivatives designed for the $\left[{ }^{99 \mathrm{~m}} \mathrm{Tc}(\mathrm{N})(\mathrm{PNP})\right]^{2+}$ metal fragment. Nucl. Med. Biol. 2007, 34, 511-522. [CrossRef]

131. Bolzati, C.; Mahmood, A.; Malagò, E.; Uccelli, L.; Boschi, A.; Jones, A.G.; Refosco, F.; Duatti, A.; Tisato, F. The $\left[{ }^{99 \mathrm{~m}} \mathrm{Tc}(\mathrm{N})(\mathrm{PNP})\right]^{2+}$ Metal Fragment: A Technetium-Nitrido Synthon for Use with Biologically Active Molecules. The N-(2-Methoxyphenyl)piperazyl-cysteine Analogues as Examples. Bioconjug. Chem. 2003, 14, 1231-1242. [CrossRef]

132. Boschi, A.; Uccelli, L.; Duatti, A.; Bolzati, C.; Refosco, F.; Tisato, F.; Romagnoli, R.; Baraldi, P.G.; Varani, K.; Borea, P.A. Asymmetrical Nitrido Tc-99m Heterocomplexes as Potential Imaging Agents for Benzodiazepine Receptors. Bioconjug. Chem. 2003, 14, 1279-1288. [CrossRef]

133. Baraldi, P.G.; Romagnoli, R.; Duatti, A.; Bolzati, C.; Piffanelli, A.; Bianchi, N.; Mischiati, C.; Gambari, R. Synthesis of hybrid distamycin-cysteine labeled with ${ }^{99 \mathrm{~m}} \mathrm{Tc}$ : A model for a novel class of cancer imaging agents. Bioorg. Med. Chem. Lett. 2000, 10, 1397-1400. [CrossRef]

134. Vats, K.; Subramanian, S.; Mathur, A.; Sarma, H.D.; Banerjee, S. Radiosynthesis and evaluation of a ${ }^{99 m}$ Tc-folic acid radiotracer prepared using $\left[{ }^{99} \mathrm{~m} \mathrm{TcN}(\mathrm{PNP})\right]^{2+}$ metal fragment. Bioorg. Med. Chem. Lett. 2017, 27, 1329-1332. [CrossRef] [PubMed]

135. Agostini, S.; Bolzati, C.; Didone, E.; Cavazza-Ceccato, M.; Refosco, F.; Aloj, L.; Arra, C.; Aurilio, M.; Tornesello, A.L.; Tesauro, D.; et al. The $[\mathrm{Tc}(\mathrm{N})(\mathrm{PNP})]^{2+}$ metal fragment labeled cholecystokinin-8 (CCK8) peptide for CCK-2 receptors imaging: In vitro and in vivo studies. J. Pept. Sci. 2007, 13, 211-219. [CrossRef] [PubMed]

136. Decristoforo, C.; Santos, I.; Pietzsch, H.J.; Kuenstler, J.U.; Duatti, A.; Smith, C.J.; Rey, A.; Alberto, R.; Von Guggenberg, E.; Haubner, R. Comparison of in vitro and in vivo properties of [Tc-99m]cRGD peptides labeled using different novel Tc-cores. Q. J. Nucl. Med. Mol. Imaging 2007, 51, 33-41. [PubMed]

137. Mukherjee, A.; Kothari, K.; Tóth, G.; Szemenyei, E.; Sarma, H.D.; Környei, J.; Venkatesh, M. ${ }^{99 m}$ Tc-labeled annexin V fragments: A potential SPECT radiopharmaceutical for imaging cell death. Nucl. Med. Biol. 2006, 33, 635-643. [CrossRef] [PubMed]

138. Faintuch, B.L.; Teodoro, R.; Duatti, A.; Muramoto, E.; Faintuch, S.; Smith, C.J. Radiolabeled bombesin analogs for prostate cancer diagnosis: Preclinical studies. Nucl. Med. Biol. 2008, 35, 401-411. [CrossRef] [PubMed]

139. Carta, D.; Salvarese, N.; Morellato, N.; Gao, F.; Sihver, W.; Pietzsch, H.J.; Biondi, B.; Ruzza, P.; Refosco, F.; Carpanese, D.; et al. Melanoma targeting with [ $\left.{ }^{99 \mathrm{~m}} \mathrm{Tc}(\mathrm{N})(\mathrm{PNP})\right]$-labeled $\alpha$-melanocyte stimulating hormone peptide analogs: Effects of cyclization on the radiopharmaceutical properties. Nucl. Med. Biol. 2016, 43, 788-801. [CrossRef]

140. Bolzati, C.; Salvarese, N.; Carpanese, D.; Seraglia, R.; Meléndez-Alafort, L.; Rosato, A.; Capasso, D.; Saviano, M.; Del Gatto, A.; Comegna, D.; et al. [ $\left.{ }^{99 \mathrm{~m}} \mathrm{Tc}\right][\mathrm{Tc}(\mathrm{N})$ PNP43]-Labeled RGD Peptides As New Probes for a Selective Detection of $\alpha_{v} \beta_{3}$ Integrin: Synthesis, Structure-Activity and Pharmacokinetic Studies. J. Med. Chem. 2018, 61, 9596-9610. [CrossRef]

141. Boschi, A.; Cazzola, E.; Uccelli, L.; Pasquali, M.; Ferretti, V.; Bertolasi, V.; Duatti, A. Rhenium(V) and Technetium(V) Nitrido Complexes with Mixed Tridentate $\pi$-Donor and Monodentate $\pi$-Acceptor Ligands. Inorg. Chem. 2012, 51, 3130-3137. [CrossRef]

142. Boschi, A.; Uccelli, L.; Pasquali, M.; Pasqualini, R.; Guerrini, R.; Duatti, A. Mixed Tridentate $\pi$-Donor and Monodentate $\pi$-Acceptor Ligands as Chelating Systems for Rhenium-188 and Technetium-99m Nitrido Radiopharmaceuticals. Curr. Radiopharm. 2013, 6, 137-145. [CrossRef] 
143. Boschi, A.; Pasquali, M.; Trapella, C.; Massi, A.; Martini, P.; Duatti, A.; Guerrini, R.; Zanirato, V.; Fantinati, A.; Marzola, E.; et al. Design and Synthesis of ${ }^{99} \mathrm{~m}$ TcN-Labeled Dextran-Mannose Derivatives for Sentinel Lymph Node Detection. Pharmaceuticals 2018, 11, 70. [CrossRef] [PubMed]

144. Smilkov, K.; Janevik, E.; Guerrini, R.; Pasquali, M.; Boschi, A.; Uccelli, L.; Di Domenico, G.; Duatti, A. Preparation and first biological evaluation of novel Re-188/Tc-99m peptide conjugates with substance-P. Appl. Radiat. Isot. 2014, 92, 25-31. [CrossRef] [PubMed]

145. Bolzati, C.; Boschi, A.; Uccelli, L.; Malagò, E.; Duatti, A.; Pasqualini, R.; Giganti, M.; Piffanelli, A. Mixed Technetium-99m Nitrido Complexes with Dithiocarbamate and Phosphine-Thiol Ligands; Nicolini, M., Mazzi, U., Eds.; SGE Editoriali-Padova Italy: Padova, Italy, 1999; Volume 5, pp. 615-619.

146. Auzeloux, P.; Papon, J.; Azim, E.M.; Borel, M.; Pasqualini, R.; Veyre, A.; Madelmont, J.-C. A Potential Melanoma Tracer: Synthesis, Radiolabeling, and Biodistribution in Mice of a New Nitridotechnetium Bis(aminothiol) Derivative Pharmacomodulated by a N-(Diethylaminoethyl)benzamide. J. Med. Chem. 2000, 43, 190-198. [CrossRef] [PubMed]

(C) 2019 by the authors. Licensee MDPI, Basel, Switzerland. This article is an open access article distributed under the terms and conditions of the Creative Commons Attribution (CC BY) license (http://creativecommons.org/licenses/by/4.0/). 